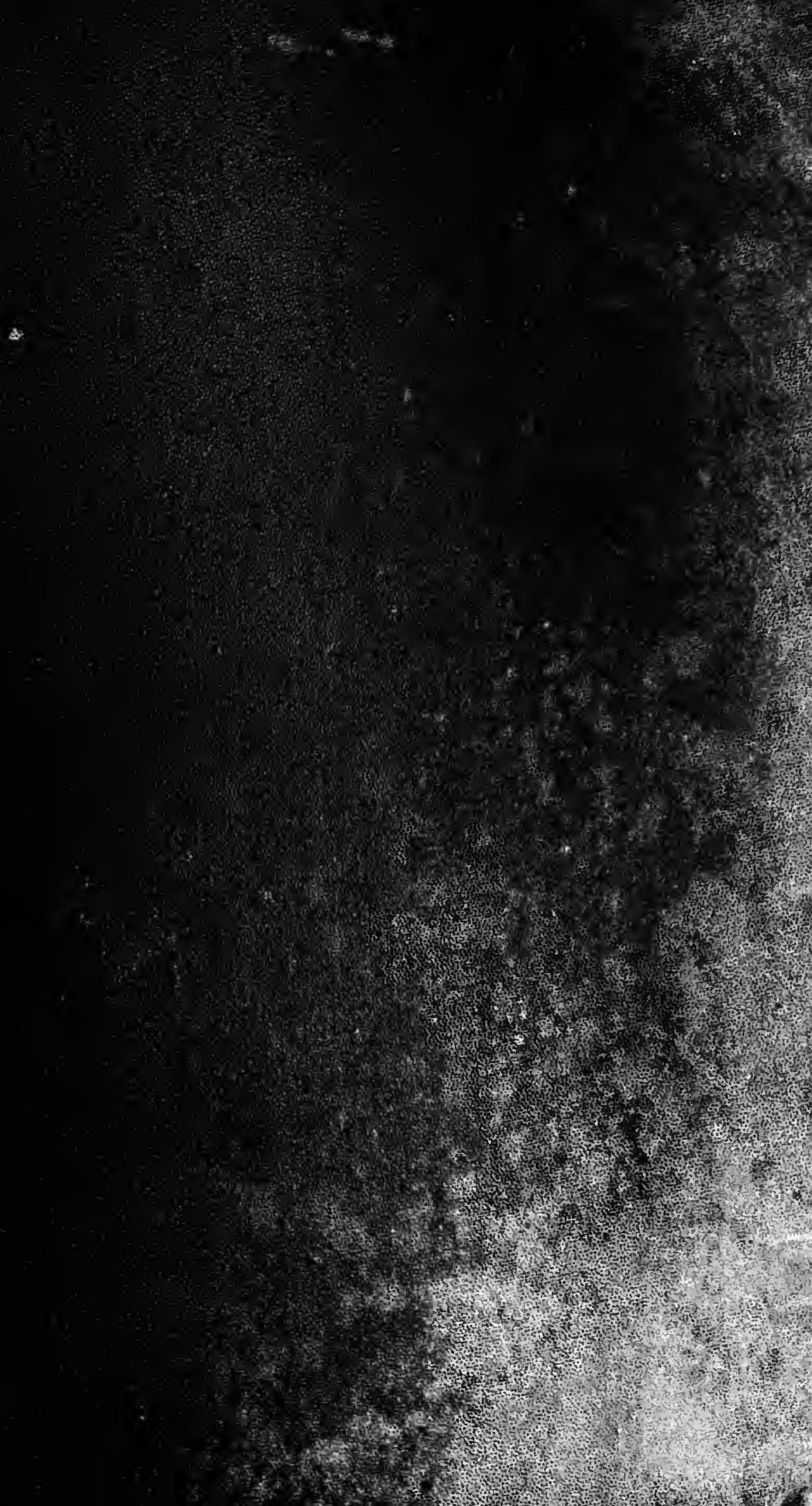


表210

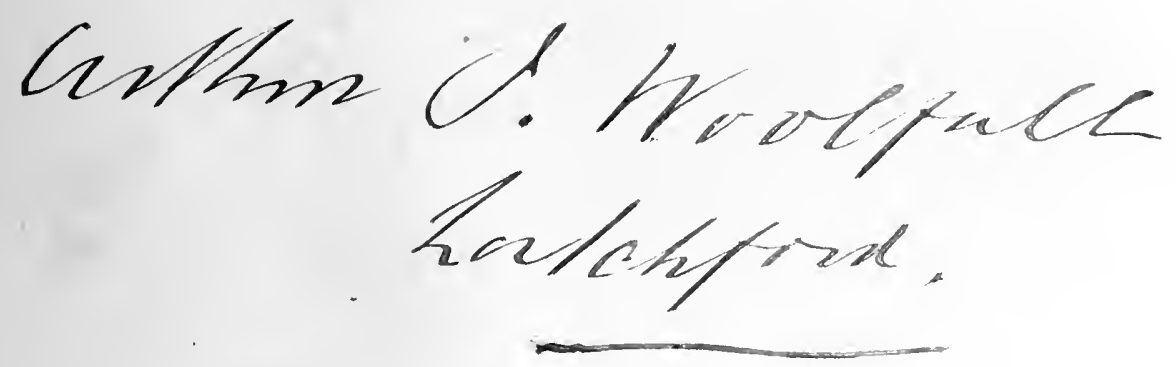




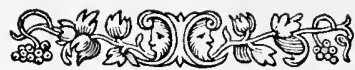

POEMS AND LANCASHIRE S O N G S. 


\section{Digitized by the Internet Archive in 2007 with funding from Microsoft Corporation}




\title{
POEMS AND LANCASHIRE SONGS
}

\author{
BY EDIVIN WAUGII.
}

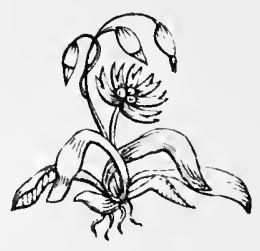

FOURTH EDITION, WITH AIDITIOAS.

MANCIIESTER :

$\triangle \mathrm{BEL}$ HEYWOOD AND SON.

LONDON :

SIMPKIN, MARSHALL AND CO.

1876. 


$$
\begin{aligned}
& P R \\
& 5760 \\
& W \geqslant \\
& 1876
\end{aligned}
$$

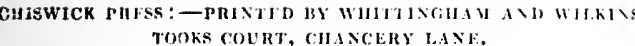


THE RIGHT HONOLRABIE

IOHN BRIGIIT, M.P. 



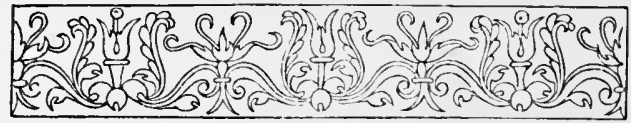

\section{CONTENTS.}

\section{POEMS.}

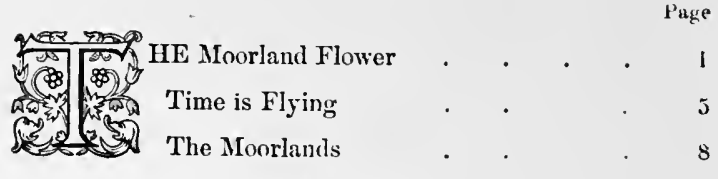

To the Rose-tree on My Window-sill . . . . 11

Keen Blows the North Wind . . . . . 23

The Captain's Friends $\quad$. $\quad$. $\quad$. 26

Now Summer's Sunlight Glowing . . . . 31

The World . . . . . . . . 35

To a Married Lady $\quad$ • $\quad . \quad$. $\quad . \quad$. $\quad . \quad$. 39

Cultivate your Men . $\quad$. $\quad$. $\quad$. $\quad$. $\quad$. 42

Old Man's Song '. . . . . . . . 45

Bide on . . . . . . . . . . 48

The Moorland Witch . . . . . . . 51

The Church Cluck . . . . . . . 54

God bless thee, Old Engrland . . . . . . 57

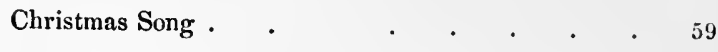


Page

God bless thi Silver Yure . . . . . . 221

Margit's Comin' . . . . . . . 226

Th' Sweetheart Gate . . . . . . . 23.2

Owd Enoch $\quad . \quad$. . . . . . . 236

Eawr Folk . . . . . . . . . 246

Forgive One Another . . . . . . 252

Buckle to . . . . . . . . . 256

Neet-fo' . . . . . . . . . 260

A Lift on the Way . . . . . . . 265

Yesterneet . . . . . . . . 270

Bonny Nan . . . . . . . . 275

I've worn my Bits o' Shoon away $\quad$. . . . 279

Gentle Jone . . . . . . . . 283

Tum Rindle $\quad . \quad$. $\quad . \quad$. . . 288

These Maund'rin E'en . . . . . . 29

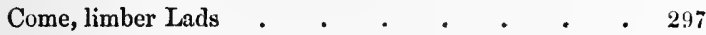

The Garland . . . . . . . . 301 


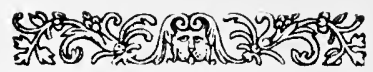

POE M S.

8 


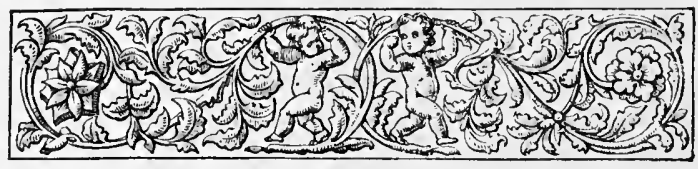

\section{POE M S.}

$\sin 203$

\section{THE MOORLAND FLOWER.}

I.

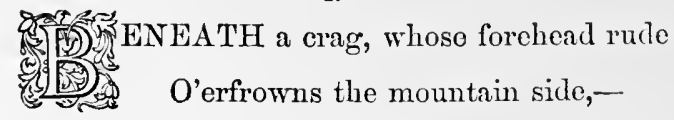

Stern monareh of the solitude,

Dark-heaving, wild, and wide,-

A floweret of the moorland hill

Peeped out unto the sky,

In a mossy nook, where a limpid rill

Came tinkling blithely hy. 
II.

Like a star-seed, from the night-skies flung Upon the mountains lone,

Into a gleaming floweret sprung,-

Amid the wild it shone;

And bush and brier, and rock and rill,

And every wandering wind,

In interchange of sweet good-will

And mutual love did bind.

III.

In the gloaming grey, at close of day,

Beneath the deepening blue,

It lifted up its little eup,

To eateh the erening dew :-

The rippling fall, the moorfowl's call,

The wandering night-wind's moan;

It heard, it felt, it loved them all,-

That floweret sweet and lone. 
IV.

The green ferm wove a sereening grove

From noontide's fervid ray;

The pearly mist of the brooklet kist

Its leaves with cooling spray;

And, when dark tempests swept the waste,

And north winds whistled wild,

The brave old rock kept off the shock,

As a mother shields her child.

\section{v.}

And when it died the south wind sighed,

The drooping fern looked dim;

The old crag moaned, the lone ash groaned, The wild heath sang a hymn;

The leaves crept near, though fallen and sere,

Like old friends mustering round;

And a dew-drop fell from the heather-bell

Upon its burial ground. . 
vi.

For it had bloomed content to bless Each thing that round it grew ;

And on its native wilderness

Its store of sweetness strew :

Fair link in nature's chain of love,

To noisy fame unknown,

There is a register above,

E'en when a flower is gone.

vII.

So, lovingly embrace thy lot,

Though lowly it may be, And beautify the little spot

Where God hath planted thee:

To win the world's approving eyes

Make thou no foolish haste,-

Heaven loves the heart that lives and dies

To bless its neighbouring waste. 


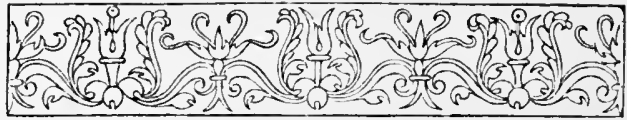

\section{TINE IS FLYING.}

I.

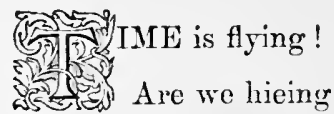

To a brighter, better bourne?

Or, unthinking,

Daily sinking

Into night that knows not mom?

II.

Oh, what is life

But duty's strife?

A drill; a watehful sentry's round; 
A brief campaign

For deathless gain;

A bivouac on battle-ground :

III.

An arrow's flight;

A taper's light;

A fitful day of sun and cloud;

A flower; a shade;

A journey made

Between a cradle and a shroud.

IV.

Oh, what is death?

A swordless sheath;

A jubilee ; a mother's call ;

A kindly breast,

That offers rest

Unto the poorest of us all; 
v.

The wretehed's friend ;

Oppression's end ;

The outeast's shelter from the cold;

To regions dim,

The portal grim

Where misers leave their loads of gold;

rI.

A voyage o'er ;-

A misty shore,

With time-wrecked gererations strown;

Where each mad age

Has spent its rage

Upon a continent unknown. 


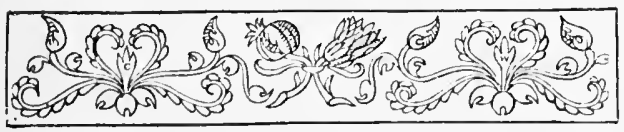

\section{THE MOORLANDS.}

I.

ING, hey for the moorlands, wild, lonely, and stern,

Where the moss creepeth softly all under the fern ;

Where the heather-flower swcetens the lone highland lea,

And the mountain winds whistle so fresh and so free!

l've wandered o'er landscapes embroidered with flowers,

The richest, the rarest, in greenest of bowers, Where the throstle's sweet vesper, at summer day's close, 
Shook the coronal dews on the rim of the rose;

But, oh for the hills where the heather-cock springs

From his nest in the bracken, with dew on his wings !

Sing, hey for the moorlands!

II.

I've lingered by streamlets that water green plains,

I've mused in the sunlight of shady old lanes,

Where the mild breath of evening came swectly and slow

From green nooks where bluebells and primroses grow ;

But, oh the wild hills that look up at the skies, Where the green bracken wave to the wind as it flies!

Sing, hey for the moorlands! 
III.

Away with the pride and the fume of the town, And give me a lodge in the heatherland brown; Oh there, to the schemes of the city unknown, Let me wander with freedom and nature, alone; Where wild hawks with glee on the hurricane sail, And the mountain erags thrill to the rush of the gale! Sing, hey for the moorlands!

IV.

In glens which resound to the waterfall's song, My spirit should play the wild echoes among: I 'd climb the dark steep to my lone mountain home, And, heartsome and poor, o'er the solitude roam : And the keen winds that harp on the heathery lea Should sing the grand anthem of freedom to me!

Sing, hey for the moorlands! 


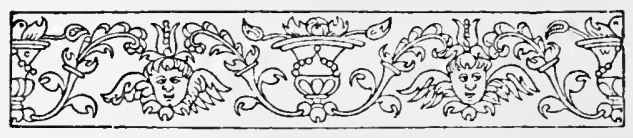

TO THE ROSE-TREE ON MY

WINDOW-SILL.

I.

min

By sensual appetite's unbridled sway,

As to be blind unto the beautiful

In common things that strew the common way.

Trailing the dusty elements of death,

He crawls, in his embruted blindness, proud;

To perishable ends he draws his breath;

His life, a funeral passing through a crowd ;

His soul, a shrunken corpse within; his body, but

a shroud. 
II.

Nature! kind handmaid of the thoughtful soul, Be. thy sweet ministrations ever mine;

Thy angel-influences keep me whole, And lead my spirit into things divine :

Holding thy lovely garment, when a child, I walked in simple ecstasy with thee; And now, with sadder heart, and travel-toiled, Thou hast a sanctuary still for me, Where oft I find repose from earthly carc and misery.

III.

In cities proud, by grovelling factions torn, Where glittering pomp and stony-eyed despair, Murder and stealth, the lordly and the lorn, Squalor and wealth, divide the Christian air;Where prowling outeasts hug with ignorant rage Some sense of wrong that smoulders deep within ;- 
Where mean intrigues their furtive battles wage ;

Where they are wrong tliat lose, and they are right that win,-

And drowning virtue struggles with the waves of $\sin ;-$

IV.

Where drooping penitence, and pious pride;

The sons of labour and the beasts of prey;

The spoilers and the spoiled, are side by side, Jostling unkindly on the crowded way ;-

E'en there sweet Nature sings her heaven-taught songs, -

Unheeded minstrel of the fuming street,-

For ever wooing its diseordant throngs

With sounds and shapes that teem with lessous meet, -

Like thee, fair rose-tree, on my window blooming sweet. 
V.

Oh, floral comrade of my lonely hours,

Sweet soother of my saddest mood,

The summer's glow, the scents of summer flowers, Are filling all my solitude:

The thick-leaved groves, whose sylvan rooflets ring

With blending lyries poured from every tree, The sleepy streams where swallows dip the wing,

The wild flowers, nodding in the wind, I see,And hear the murmurous music of the roving bee.

$\nabla \mathrm{I}$.

Taking my willing fancy by the hand,

Thou leadest me througl nature like a child, Where rustling forests robe the pleasant land, And lonely streamlets ripple through the wild ;- 
Through verdant nooks, where, on the long, cool grass

The lingering dews light up the leafy shade, In dreamy bliss, my wandering footsteps pass,

Sweeping from many a lush and bending blade The load of liquid pearls that such a twinkling made.

VII.

Now, through a sunny glade, away, away,-

Oh, let me wander thus a while with thee,By many a pleasant streamlet we will play, And gad o'er many a field in careless glee: Thus gently, thou, when on life's pathway rude My heart grows faint as gloomy shadows lower,

Leadest me back into a happier mood, By some sweet, secret, heaven-inspiréd power, That lurks in thy fringed leaf and orient-tinted flower. 
VIII.

My spirit bursts its prison-house of care, And dreamily, with lingering feet, I stray Where garden odours fill the golden air, And blossoms tremble to the wild birds' lay ;O'er cool moist slopes, bencath the woodland shade,

Where the blithe throstle in his chamber sings, Then wonders at the music he has made;-

Where the lush bluebell's little eenser swings, And pleasant incense to the wandering breczes flings.

IX.

Upon a shady bank, as I recline, Gazing, with silent joy, the landscape o'er,

I feel its varicd glories doubly mineMy heart's inheritance, my fancy's store; 
Above me waves a roof of green and gold-

Delightful shelter from the noontide heat;

Beyond, a wandering streamlet I behold,

Where wind and sunlight on the waters meet

In silvery shimmerings, past description swect.

$\mathbf{x}$.

I hear the skylark, poised on trembling wings,

Teaching the heavenly quire his thrilling lay,

All nature seems to listen as he sings,

Hushed into stillness by his minstrelsy ;-

As the blithe lyric streams upon the lea,

Steeping the wild flowers in melodious rain,

The very dewdrops, dancing to the glee,

Look up with me, but, like me, look in vain

To find the heaven-hid singer of that matchless strain. 
XI.

Now, on rough byways, sauntering through the sun,

From fertile haunts of man I gladly stray,

Up to the sweet brown moorlands, bleak and dun,

While rindling waters tinkle o'er my way;

Where the free eagle lords it in the sky;

Where red grouse, springing from the heath'ry steep,

Wake the wild echoes with their lonely cry;

And whistling breezes unrestrainèd sweep

O'er the old hills, that in the sunlight seem asleep.

XII.

O'er yon wild height, between the rugged steers, From crag to crag, in many an airy bound Of mighty glee, the mountain torrent leaps, And the lone ravine trembles to the sound; 
Through cave and cleft, along the narrow glen, The rushing thunders rage, and roll afar,

Like untamed lions struggling in their den,-

With unavailing rage,-each rocky scar

Hurls back the prisoned roar of elemental war.

XIII.

As homeward, down a winding path I stray,

Where mazy midges in the twilight throng

In plaintive fits of liquid melody,

I hear the lonely ousel's vesper-song;

Odours of unseen flowers the air pervade;

As I sit listening on a wayside mound,

Watching the daylight and its business fade,

The evening stillness fills with weird sound,

And distant waters sing their ancient choral round.

XIV.

Mild evening brings the gauzy fringe of dreams

That trails upon the golden skirts of day; 
And here and there a cottage candle gleams

With cheerful twinkle o'er my drowsy way;

As flaxen-headed elves, from rambles wild,

With straggling footsteps, to their mothers hie

With woodland trophies, and with garments soiled,

All tired and pleased,-they know not, care not why;-

So from my wand'rings I return, as daylight quits the sky.

$\mathrm{x} \nabla$.

Oh, flowery leader of these fancy flights, Epitome of Nature's charms to me, Filling my spirit with such fine delights As I can never more repay to thee,For my behoof thou donn'st the summer's sheen, Smiling benignly on thy prison-spot, 
Though exiled from that native nook of green Where playmate zephyrs seek through bower and grot,

Through all the summer roses seek, but find thee not.

XVI.

Fair lamp of beauty, in my cloistral shade, Though brief at best the time thou hast to shine,

By an almighty artist thou wert made, And touched with light eternally divine.

Like a caged bird, in this seclusion dim,Where slanting sunbeams seldom find a way,-

Singing with patient joy a silent hymn, That wafts my thought from worldly care away

Into the realms of Nature's endless holiday. 
XYII.

Sweet speeimen of Nature's mystie skill, Dost thou know aught of human joys and woes?

Can'st thou be gladdened by the glad heart's thrill,

Or feel the writhing spirit's silent throes?

To me thou art a messenger of love-

A leaf of peace amid the storms of woo-

Dropt in my path by that celestial Dore

Who made all things in hearen and earth below,

That wandering man the beautiful and true might know.

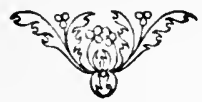




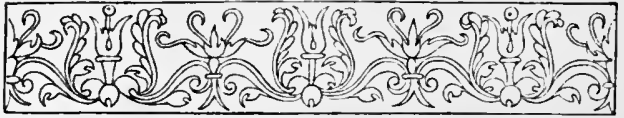

\section{KEEN BLOWS THE NORTH WIND.}

I.

河 lands are bare;

The snow-shroud lies white on the flowerless len; The red-breast is wailing the death of the year, As be cowers his wing in the frozen haw-tree.

II.

The leaves of the forest, now summer is o'er, Lie softly asleep in the lap of decay; And the wildflower rests on the snow-covered shore, Till the cold night of winter has wandered away. 
III.

$\mathrm{Oh}$, where are the small birds that sang in yon bowers

When last summer smiled on the green-mantled plain?

$\mathrm{Oh}$, where do they shelter in winter's bleak hours? Will they come back with spring, to delight me again?

IV.

But I may be gone, never more to behold

The wildflowers peep, when the winter has fled; The chill drifts of sorrow the wanderer may fold, And the sunshine of spring melt the snow on his bed.

But come, ye sweet warblers, and sport in the spray, Whose tender revival I never may see; 
The young buds will leap to your welcoming lay,-'Twill cheer the sad-hearted, as oft it cheered me.

vI.

And should ye, returning, then find me at rest, Stay sometimes, and sing near the grave of a friend;

Drop a rosemary leaf on his turf-covered breast, And rejoice that his troublesome journey's at end. 


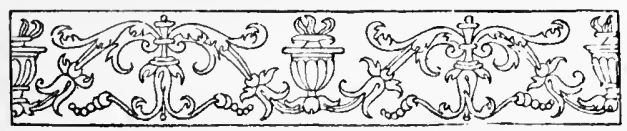

THE CAPTAIN'S FRIENDS.

I.

WANDERED down by yonder park one quiet autumn day,

When many a humble traveller was going on the way;

And there I saw a company of neighbours great and small,

All gathered round an ancient gate that leads unto the hall.

11.

The faded leaves that rustled in the mournful autumn wind

Awoke in me a train of thought that saddened all my mind; 
And through the crowd of anxious folk there went a smothered wail,

So I sat me down upon a stone and hearkened to the tale.

III.

The sturdy farmer from his fields had hurried to the place,

The cripple on his erutches, and the sick with pallid face;

The poor old dame had wandered with her blind man to the ground,

And the lonely widow, weeping, with her children gathered round.

IT.

The well remembered beggar, too, was there-but not to beg;

And the stiff old Chelsea pensioner, upon a wooden $\operatorname{leg}$ : 
From hamlet, fold, and lonely cot, the liumble poor were there,

Each bringing in his moistened eye a tributary tear.

V.

Up spake the sturdy farmer to the porter, and he said,

"What news is this that's going round? They say the Captain's dead!"

The quaint old porter laughed, "Aha! Thank God, it isn't true !

It's but the Captain's dog that's dead-they called it ' Captain' too !"

VI.

Then sprang the cripple on his crutch, and nearly came to ground;

The blind man wandered to and fro, and shook their hands all romd; 
The dame took snuff, the sick man smiled, and blest the happy day;

And the widow kissed her young ones, as she wiped their tears away.

VII.

Up rose the children's voices, mingling music with the gale,

And the beggar's dog romped with them, as he barked and wagged his tail ;

The farmer snapt his thmmbs, and cried, "Come on, I'll feast you all!"

And the stark old soldier with his stick kept charging at the wall.

VIII.

So, now the Captain's dog is dead and slecping in the ground, A kind old master by the grave bemoans his gallant hound; 
He says, "My hair is white and thin! I lave not long to stay!

And, oh, my poor old dog, how I shall miss thee on the way!"

IX.

Then here's to every noble heart that 's gentle, just, and brave,

That cannot be a tyrant, and that grieves to see a slave.

God save that good old Captain long, and bring his soul to joy;-

The countryside will lose a friend the day he comes to die.

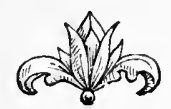




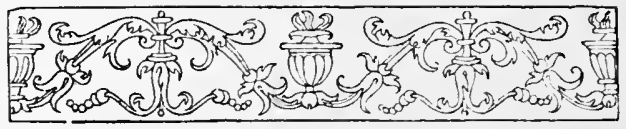

NOW SUMNER'S SUNLIGHT GLOWING.

I.

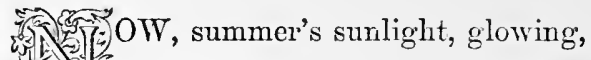

急造 Streaks the woodland shade with goll;

And balmy winds are blowing

Softly o'er the moorland-wold;

Now sweet smells the bluebell,

'Neath the valley's leafy screen;

And thick grows the wild rose,

Clust'ring o'er the hedges green.

The fern adorns the moorland steep;

The smiling fields are flowered o'er;

And modest little daisies peep

Like ehildren at a mother's door! 
II.

From dewy meadows springing,

Yonder blinding skies among,

The poet-lark is singing,

As if his heart was made of song!

While gladly and madly

In every grove the wild birds vie,

All tingling and mingling

In tipsy routs of lyric joy!

My throbbing heart with every part

Is dancing to the chorus near,-

The gush, the thrill,- the wizard trill-

Like drops of water tinkling clear!

III.

The cottage matron, knitting

In her little garden, sings,

As wild birds, round her flitting,

Fan the blossom with their wings; 
And twining, combining,

The honeysuckle and the rose,

Sweet shading, and braiding,

Round her winking lattice goes;

And wild bees through the flowers roam-

The little happy buzzing thieres !-

Here and there, with busy hum,

Rifling all the honejed leaves.

IV.

Now, hamlet urchins roaming,

All the sunnj summer das,

From dewy morn till gloaming,

Through the rustling wildwood stray;

There blithely and lithely,

By warbling brook and sylvan grot,

They ramble and gambol,

All the busy world forgot;-

F 
Like birds that wing the sumny air, And warble in the tangled wild,

Unhaunted by the dreams of care,$\mathrm{Oh}$, to be again a child!

v.

Sweet scents and sunshine blending;

The wildwoods, in their leafy pride,

To the gentle south wind bending;$\mathrm{Oh}$, the bonny summer tide!

The tinkling, the twinkling, Where little limpid rivers lave;

The sipping, the dipping Of wild-flowers in the gilded wave;The fruitful leas, the blooming trees, The pleasant fields, embroidered fair; The wild birds' little melodies, Seattering gladness everywhere! 


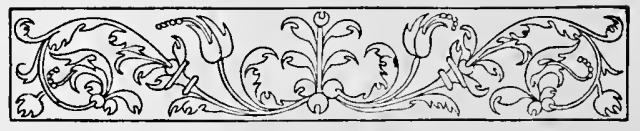

\section{THE WORLD.}

I.

And, whon it thinks, it thinks
Its thoughts are hid.

II.

Its piety's a screcn

Where vice doth hide;

Its purity's unclean;

Its meekness, pride. 
III.

Its charity's a bait

To catch a name ;

Its kindness covers hate;

Its praise is blame.

IV.

Its wisdom soweth seeds

Which follies prove;

And its repentance needs

Repenting of.

v.

Its learning 's empty talk;

Its heart is cold;

Its church is an exchange;

Its god is gold. 
ri.

Its pleasures all are blind, And lead to pain;

Its treasures are a kind Of losing gain.

VII.

Lust moves it more than love,

Fear more than shame;

Its best ambitions have

A grovelling aim.

vili.

Its laws are a disgrace;

Its lords are slaves;

Its honours are misplaced,

E'on on our graves. 
IX.

Some sorrow doth attend

Its happiest dreams;

And rottenness doth end

Its rotten schemes.

$\mathrm{x}$.

Oh, eure this moral madness-

This soul-discase ;

Shew ns that Vice brings sadness,

And Virtue, ease.

$\mathrm{XI}$.

And teach us in the hour

Of Sin's dismay,

That Truth's the only flower

Without decay. 


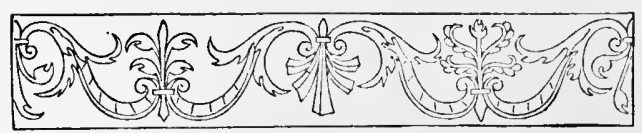

TO A MARRIED LADY.

1.

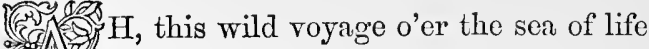

Needs all the help that heaven to earth

can give ;

Through its dark storms, and shoals, and battlestrife

God must be pilot to the ships that live.

II.

Happy the heart that finds a haven of love,

Where in the tempest it can sweetly moor,

And taste, below, the bliss that but above,

Is ever stainless, and is ever sure. 
III.

And blest the hearth where puro affections glowThe husband's and the father's best retreat; Where heavenward souls in one direction grow, With darling tendrils round them twining sweet.

IT.

Such be thy home; through earth's mutations strange,

A garden, where the flowers of heaven grow ;

And, sheltered there from blight, through every change,

Its loves, its hopes, no touch of ruin know.

V.

May Time, whose withering finger ever brings, To Nature's best the doom of sure decline, Float over thee with gently-fanning wings, And find the twilight of thy life divine. 
TI.

And, ever hand in hand, along sour path,-

For thee and thine thus doth the poet pray,-

That ye may walk in joy from life to death,

And earth's night be the dawn of hearen's day.

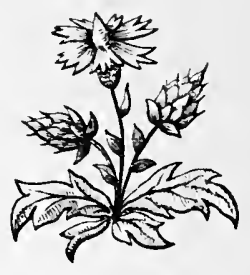




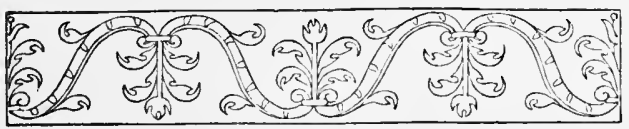

CULTIVATE YOUR MEN.

अभुลี

ILL as ye ought your barren lands, And drain your moss and fen;

Give honest work to willing hands, And food to hungry men;

And hearken - all that have an ear-

To this unhappy ery,-

" Are poor folks' only chances here

To beg, to thieve, or die?"

II.

With kindly guerdon this green earth

Rewards the tiller's care, And to the wakening hand gives forth

The bounty slumbering there; 
But there's another, nobler field

Big with immortal gain,-

The morasses of mind untilled;-

Go,-cultivate yonr men !

III.

Oh, ponder well, ye pompous men,

With Mammon-blinded ejes,

What means the poverty and pain

That moaning round you lies:

Go, plough the wastes of human mind

Where weedy ignorance grows, -

The baleful deserts of mankind

Would blossom like the rose.

IV.

But penny-wise, pound-foolish thrift

Deludes this venal age;

Blind self's the all-engrossing drift,

And pelf, the sovereign rage. 
E'en in the Church, the lamp grows dim,

That ought to light to heaven, And that which fed its holy flane, To low ambition's given.

T.

Just retribution hovers near This play of pride and tears;

To heaven all worldly cant is clear, Whatever cloak it wears; And high and low are on one path, Which leads into the grave,Where false distinetions flit from death, And tyrant blends with slave.

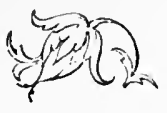




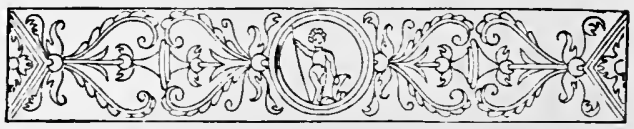

OLD MAN'S SONG.

I.

$\mathrm{H}$ ! sweetly the morning of childliood

Awoke me to careless delight;

And blithe as a bird of the wildwood

I plajed in its beantiful light;

The world was a magical treasure

That filled me with wonder and jor;

And I fluttered from pleasure to pleasure,

Delighted-I couldn't tell why :

If I thought of to-morrow,

I dreamt not of sorrow;

And I smiled as the day went hy. 
II.

Gay youth, with its glittering hours, Came frolicking on, full of glec, Where hope's charming sunlighted bowers Were thickly in blossom for me;My heart was an harp whose emotion Awoke to all beantiful things, And love was the dearest devotion That played in its tremulous strings : So, I dallied, delighted, And carelessly slighted Old Time and his rustling wings.

III.

Now, the noontide of life has gone by me, The visions of morning have died; And the world is beginning to try me With struggles that cliasten mv pride;- 
As the twilight of time, softly stealing,

Comes o'er me with shadows of grey,

I feel the sad truth now revealing,-

It draws to the close of the day;

And thoughtfully eyeing

The past, I sit sighing,

And wondering how long I shall stay.

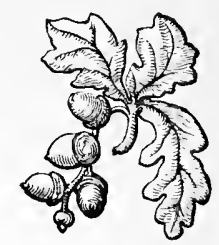




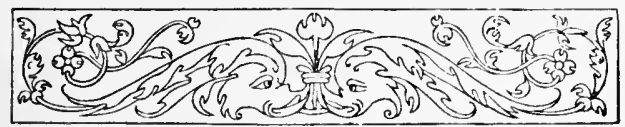

BIDE ON.

I.

HEN thy heart 'neath its trouble sinks

(1)

als down,

And the joys that misled it are gone,-

When the hopes that inspired it are flown,

And it gropes in the darkness alone,-

Let faith be thy cheer,

Scorn the whispers of fear,

Be righteous, and bravely bide on.

II.

When fancy's wild meteor-ray

Allures thee from duty to roam, 
Beware its bewildering way,

And rest with thy conseience at home;-

Give ear to its voice;

Let the stream of thy joys

From the fountain of purity come.

III.

When, by failure and folly borne down,

The future looks hopelessly drear;

And each day, as it flies, with a frown,

Tells how helpless, how abject we are;

Let nothing dismay

Thy bold effort to-day;-

Be patient, and still persevere.

IV.

Be steady, in joy and in sorrow;

Be truthful, in great and in small; 
Fear nothing but sin, and each morrow

Heaven's blessing upon thee shall fall:

In thy worst tribulation

Shun low consolation,

And trust in the God that sees all.

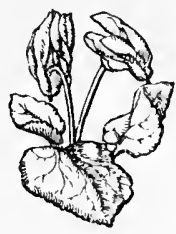




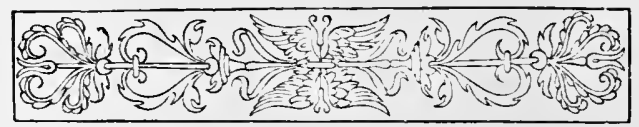

THE MOORLAND WITCH.

I.

(r) THERE lives a lass on yonder moorShe wears a gown of green;

She's handsome, young, and sprightly,

With a pair of roguish een :

She's graceful as the mountain doe

That snuffs the forest air;

And she brings the smell of the heather-bell

In the tresses of her hair.

II.

'Twas roaming eareless o'er the hills,

As sunlight left the sky,

That first I met this moorland maiden

Bringing home her kye: 
Her native grace, her lovely face,

The pride of art outshone; -

I wondered that so sweet a flower

Should blossom thus alone.

III.

Alas, that ever I should meet

Those beaming eyes of bluc,

That round about my thoughtless heart

Their strong enchantment threw.

I could not dream that falsehood lurked

In such an angel smile;

I could not fly the fate that lured

With sueh a lovely wile.

IV.

And when she eomes into the vale,

To try her beauty's power,

She'll leave a spell on many a heart

That fluttered free before. 
But, oh, beware her witching smile,'Tis but a fowler's snare;

She's fickle as the mountain wind That frolies with her hair !

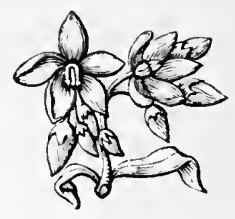




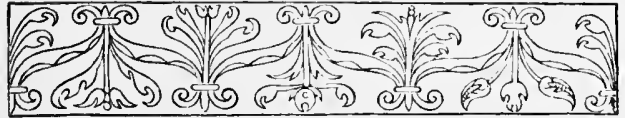

THE CHURCH CLOCK.

I.

H thou, who dost these pointers sec, And hear'st the chiming hour,

Say, do I tell the time to thee, And tell thee nothing more ;-

I bid thee mark life's little day By strokes of duty done;-

A clock may stop at any time, But time will travel on.

II.

I am a preacher to a fow,-

A servant unto all,

As here I stand tick, ticking,

Like a death-watch in a wall; 
And, it were well that those who see

These fingers gliding on,

Should think a moment, now and then,

How fast the moments run.

III.

There's some of you are wealthy,

And some of you are proud;

And some are poor, and some are sad,

And waiting for a shroud;-

Be patient yet a while, for see

This little yard bolow,-

The man who goes the longest way,

Has not so far to go.

IV.

A christ'ning; then, a wedding comes ;

And then, a passing bell;

'Tis just the ancient tale that time

Has always had to tell: 
The very clock that marks the hour, With ticking wears away;

The gladdest pulse of life contains The music of decay.

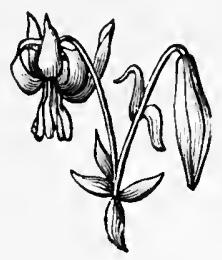




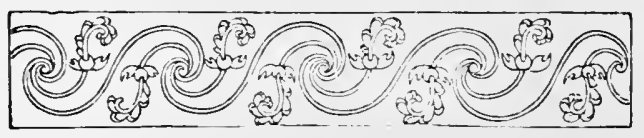

GOD BLESS THEE, OLD ENGLAND!

I.

今 (the free;

A garden of roses, begirt by the sea!

The wild wares that fondle thy darling green shoro

Shall sing thy proud story till time be no more;

And nations unborn, looking orer the ware,

Shall tell of the isle of the free and the brare,

Where liberty's battle, through ages of old,

Was fought in the hearts of the just and the

bold;-

Old England, the Queen of the Sca! 
$5^{8}$ GOD BLESS THEE, OLD ENGIAND.

II.

May truth ever flourish thy children among;

And deeds that awaken the spirit of song

Inspire future bards with emotion divine,

Till earth has no anthem so noble as thine!

Green cradle of manliness, beanty, and worth !

May thy name be a watchword of joy in the earth

When I have long mouldered beneath the green sod,- -

A country devoted to freedom and God;-

Old England, the Quecn of the Sea! 


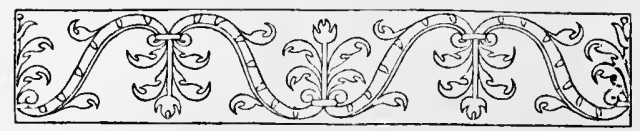

\section{CHRISTMAS SONG.}

I.

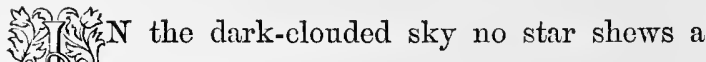
gleam ;

The drift-Iaden gale whistles wild in the tree;

The ice-mantle creeps o'er the murmuring stream,

That glittering runs through the snow-covered lea ;

But, hark! the old bells fling the nows to the wind !-

Good Christians awake to their genial eall ;The gale may blow on, we'll be merry and kind ;Blithe yule, and a happy now year to us all! 
Bring in the green holly, the box, and the yew, The fir, and the laurel, all sparkling with rime;

Hang up to the ceiling the mistletoe-bough, And let us be jolly another yule-time!

II.

While, garnished with plenty, together we meet In carolling joy, as the glad moments flee, Thus sheltered away from the frost and the sleet, With friends all around us, in festival glec, We'll still keep the heavenly lesson in mind,-

A gentle Redeemer was born at this tide; The wind may blow keenly, but we will be kind, And think of the poor folk that shiver outside. Bring in the green holly, the box, and the yew, The fir, and the laurel, all sparkling with rime;

Hang up to the ceiling the mistletoe-bongh, And let us be jolly another yule-time! 
III.

He's a cur who ean bask in the fire's checry light, And hearken, unheeded, the winter wind blow, And care not a straw for the comfortless wight Who wanders about in the frost and the snow; But we'll think of the mournful the while we are

$$
\text { glad; }
$$

Our hearts shall be kind as the winter is keen; And we'll share our good cheer with the poor and the sad,

Who sorrow and struggle in corners unseen.

Bring in the green holly, the box, and the yew, The fir, and the laurel, all sparkling with rime;

Hang up to the ceiling the mistletoe-bough, And let us be jolly another yule-time!

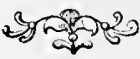




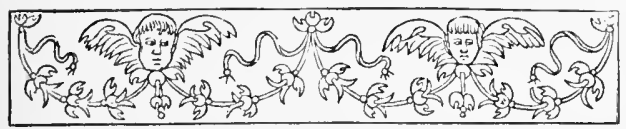

LOVE AND GOLD.

I.

\begin{abstract}
E were but poor young people,
(1) My Margaret and I;

And well I knew she loved me,

Although her looks were shy:

But I longed to see strange countries,

That lie beyond the main;

And when I'd gathered riches,

Come flaunting home again.
\end{abstract}

II.

When I parted from my true love,

A rover's fate to try,

She was full of strange forebodings,

And tears wore in her eye. 
Pale looks of silent sorrow She gave to all my glee, When I said, "I'll win some gold, love, And bring it back to thee!"

III.

But my heart was proudly beating, And I was in my prime, So, in chase of golden treasure, I went from clime to elime; In giddy chase of pleasure, Beyond the foaming sea, All heedless of the maiden Who pined at home for me.

IV. So I sought for gold, and won it, And still I wanted more, And as my treasure gathered, Was poorer than before: 
For it made me proud and heartless;

It made me hard and cold;

It made me slight my true love-

That cursèd yellow gold!

Y

But, in spite of all my riches,

I was growing old and worn;

So I took a ship for England, The place where I was born;

I took a ship for England, With all my golden storc,

To dazzle those that knew mo Full thirty years before.

VI.

When I landed with my gold-bags,

The friends of old were gone;

And, in spite of all my riches,

I felt myself alone. 
Though strangers fluttered round mo

I knew their hearts were cold;

And I sought in vain the true love,

That's never bought with gold.

\section{VII.}

My skin was parched and yellow, My hair was thin and grey, And she that loved me dearly, Was sleeping in the clay.

She had long been in the churchyard,

Sleeping sweet and sound;-

And I was but an outcast

Upon the lonely ground.

VIII.

Now to her grave I wander,

And sit upon the stone,

Where all is still and silent,-

Except my lonely moan; 
But I shall soon be going,

For I am ill and old;

And my gold will deck the mourners,

Who wish my body cold.

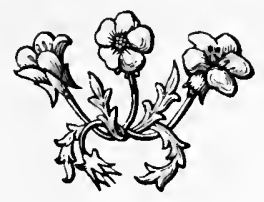




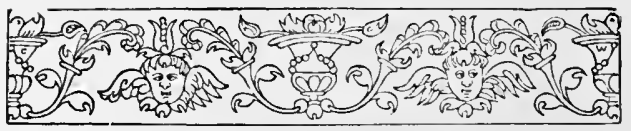

\section{ALL ON A ROSY MORN OF JUNE.}

\section{I.}

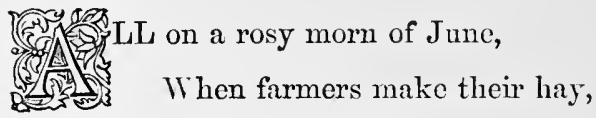

Down by yon bonny woodland green

A milking maid did stray ;

And oh, but she was sweet and fair,-

The flower of all the vale;

In her hand a wild white rose she bare, And on her head a pail.

II.

Across the fields, as she did rove,

The pretty maiden sang

A plaintive lay of tender love,

That through the valley rang: 
Blithe as a linnet on the spray, Among the wildwood green, She lilted on her flowery way,And vanished from the scene.

III.

When next I saw that pleasant vale-

Twelve moons had wandered by-

A matron told her hapless tale

With tear-drops in her eye;

For there had been, with winsome wile,

A careless-hearted lad,

And plucked the flower whose lovely smile Made all the valley glad.

IV.

The woods were gay and green again;

The sun was smiling on;

But the charmer of the rural glen

For evermore was gone: 
Now, mouldering near the churchyard way, All stricken in her pride, The white rose of the valley lay, With an infant by her side.

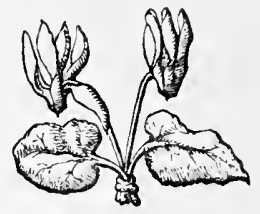




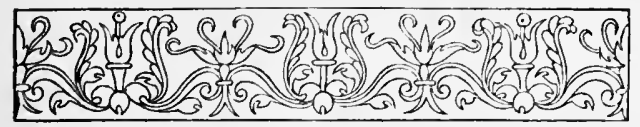

GLAD WELCOME TO MORN'S DEWY HOURS.

1.

And plays with the stream in the vale;

But, as clouds o'er the hearens come streaming,

Then silence, with shade, creeps along:

They pass,-and again the woods, gleaming,

At onec wake to sunlight and song.

II.

So I sport, till the storm gathers o'er me;

Then, pensively hushed in the gloom, 
My heart looks around and before me For something the shade to illume;

Yet though, folding the wings of my gladness,

I'm mute in the hurricane's howl, Thou com'st, through the gloomiest sadness,

A sunbeam of joy to my soul.

\section{III.}

Fair star of remembrance, endearing,

Still lend me thy brilliant ray,

My wanderings chastening and checring,

Till life, with its light, fade away;

And, oft as my pathway thou greetest,

I 'll waken my harp-string to thee, And sing how the brightest and sweetest

Are always the swiftest to flee. 


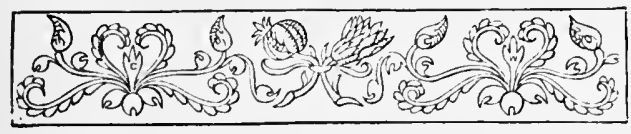

\title{
ALAS! HOW HARD IT IS TO SMILE.
}

1.

\author{
(A) \\ $3)$ \\ When all within is sad; \\ And rooted sorrow to beguile \\ By mingling with the glad. \\ The heart that swells with grief disdaing \\ Pretension's mean alloy, \\ And feels far less its kecnest pains \\ Than moekeries of joy.
}

II.

How few among the thoughtless crowds

Can tell the jealous care

With which a gentle spirit shrouds

Its pangs from worldly glare. 
The harp of sorrow wooes the touch Of sympathy alone;

Its trembling fibres shrink from such As cannot feel their tone.

III.

The gay may sport upon the wave Of life's untronbled tides,-

Like birds that warble on a grave, They dream not what it hides; But pleasure's wretched masquerade Wakes sorrow's keenest throe;The saddest look is not so sad As the strainèd smile of woe. 


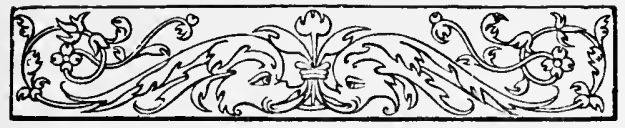

YE GALLANT MEN OF ENGLAND.

I.

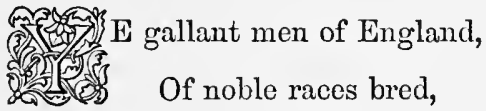

Remember how your fathers

For liberty have bled;

Stand to your ancient banners,

In a thousand battles torn-

The banners of Great Britain,

To a thousand victories borne.

II.

When flags of tyrants, flying,

Insult the air again,

And freedom's sons are dying

Upon the bloody plain, 
Rush to the gory havoc

With all your native might,

And carve your way to justice,

Or perish for the right.

III.

Ye sons of ancient heroes,

And heirs of England's fame,

Wherever danger threatens

Be worthy of your name;

And hurl each bold aggressor

Into his native lair,

To rule the slaves and traitors

That crawl around him there.

IV.

Though knaves and cowards tremble

Beneath despotie sway,

And fools to wily tyrants

Resign, a willing prey, 
The race of island lions, Bred by the Western main, The freedom won by battle By battle can maintain.

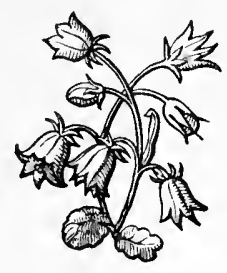




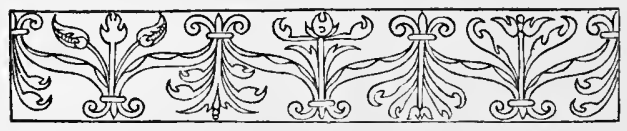

HERE'S TO MY NATIVE LAND.

I.

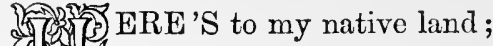

(1) And here's to the heathery hills,

Where the little birds sing on the blooming boughs,

To the dancing moorland rills.

II.

There's a lonely little cot,

And it stands by a spreading tree,

Whero a kind old face has looked from the door

Full many a time for me ;- 
III.

On the slope of a flowery dell, And hard by a rippling brook; And it's oh for a peep at the climney-top, Or a glint of the chimney-nook !

IV.

And there is a still churchyard, Where many an old friend lies; And I fain would sleep in my native ground At last, when they close my eyes.

V.

When summer days were fine, The lads of the fold and I Have roved the moors, till the harvest moon Has died in the morning sky. 
VI.

Oh, it's sweet in the leafy woods

On a sunny summer's day;

And I wish I was helping the moorland lads

To tumble their scented hay!

VIr.

Though many a pleasant nook

In many a land I've seen,

I'd wander back to my own green hills,

If the wide world lay between.

VIII.

They say there's bluer skics

Across the foaming sea:-

Each man that is born has a land of his own, And this is the land for me! 


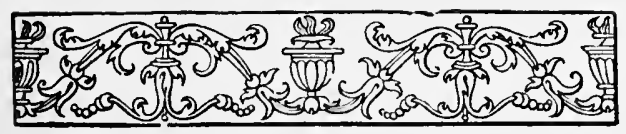

WHAT MAKES YOUR LEAVES FALL

\section{DOWN?}

I.

HAT makes your leaves fall down,
Ye drooping autumn flowers?

What makes your green go brown,

Ye fading autumn bowers?

Oh, thou complaining gale,

That wand'rest sad and lone,

What sorrows swell the tale

Of that funereal moan?

II.

Have ye felt love like mine,

And met with like return, 
That ye do thus decline,

And thus appear to mourn?

Ah, no! content, methinks,

Ye glide into decay,

As pensive evening sinks,

At close of summer day.

III.

Fall down, ye leafy bowers !

And drift upon the gales;

Fade on, ye sleepy flowers!

It is my heart that wails ;

Blow on, thou quiet wind!

It was a fancied moan-

The echo of a mind

That feels its pleasure gone.

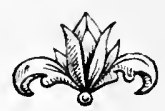




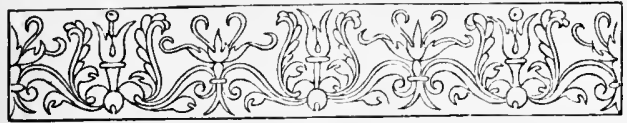

WHEN DROWSY DAYLIGHT.

I.

HEN drowsy daylight's drooping e'e Closes o'er the fading lea,--

When eveuing hums his vesper-song,

And twinkling dews the meadow throng,

I'll come to meet thee, Mary!

II.

The lazy hours refuse to fly;

As gaudy day goes creeping by,

I count each moment with a sigh,

Until the hour of shade steals nigh,

That brings me to my Mary! 
III.

The flower is dear unto the lea,

The blossom to the parent tree :-

Thou'rt more than flower and leaf to me-

This heart of mine, by love of thee,

Must bloom or wither, Mary.

IV.

The summer woods are waving fair;

The bluebell scents the evening air ;

The small bird woos its mate to share

Its little nest and loving care:-

Oh, be my own, my Mary:

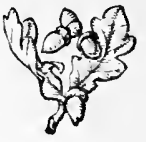




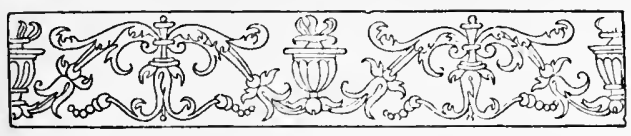

MARY.

I.

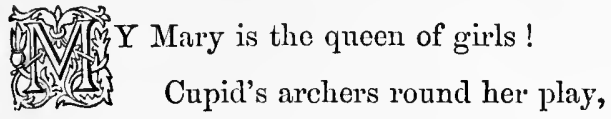

And bivouac among the curls

Which her noble head array!

II.

Her modest glances to and fro-

Ah, little knows she how they win!-

Would draw an angel down below,

Or woo the fall'n to heaven again. 
III.

The fairest form that ever playea

A poet's brightest dreams among,

Was not so lovely as the maid

That wakes this heart of mine to song.

IV.

And oh, her eyes, of heavenly hue!

The mystic spell of those twin skies, -

When love's sweet witchery lights the blue,

The stainless blue of Mary's eyes !

v.

Oh, Mary, such a love as mine

Idolatry can never be:-

Earth has no altar more divine,-

No purer paradise, for me. 


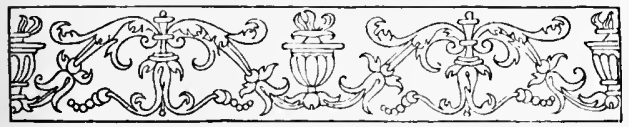

OH! HAD SHE BEEN A LOWLY MAID.

I.

$\mathrm{H}$ ! had she been a lowly maid

That stole this heart of mine,

She would have filled the humblest shade

With radianee divine:-

The moon of beauty's starry skies,

She glides serenely fair,

Absorbing in her gleaming eyes

The brightest planet there.

II.

Oh! were she but a flower of spring

Upon the dewy lea, 
OH! HAD SHE BEEN A LOWLY MAID. 87

To watch its lovely blossoming

My heart's delight would be ;

And when its leaves began to fade,

Their fading I would moan ;

And treasure up the sacred d'ist

To mingle with my own.

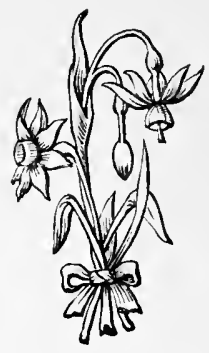




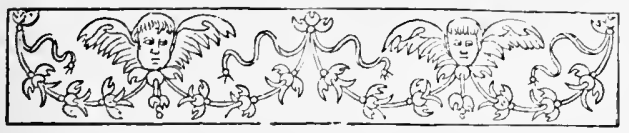

\section{THE OLD BARD'S WELCOME HOME.}

\section{RING me a goblet of drink divine, (⿻) \\ To welcome a minstrel friend of mine!}

Enfranchised from the dreary crowd,

That wrapt his spirit like a shroud,

Once more he climbs the moorlands dun,

And hears his native rindles run;

Through pleasant vales he takes his way,

Where wild-flowers with the waters play;

And listens with enehanted mind

As wizard voices in the wind

Sing of his darling native earth,

The rude, the true, the hardy north ! 
His native dales, his native streams-

The angels of his exile-dreams-

Each dingle green, each breazy height, Awakes his spirit to delight.

Oh, welcome to the fresh old hills !

The mossy crags, and tiukling rills-

To field, and wood, and moorland glen, Welcome, welcome home again!

Well may the pleasant summer air

Fondly play with thy silver hair;

Well may the brooklet's ripples clear

Leap as thy footsteps wander near;

Well may the wild-flowers on the lea,

Nodding their pretty heads to thee,

Scatter abroad their sweetest sweet,

Their fond old poet friend to meet;-

They've waited, and hare listened long;

For thee, oh, white-haired son of song! 
9० THE OLD BARD'S WELCOME HOME.

Though tempests rage and clouds are black,

The sun keeps on his glorious track,

Serenely shining, to the west,

And, grandly smiling, sinks to rest.

Thy task, old bard, is nearly done:

$\mathrm{Oh}$, may the evening coming on,

Long lingering sweetly round thy way,

Close like a cloudless summer day!

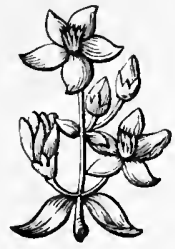




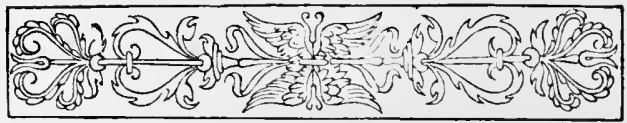

\section{OH! COME ACROSS THE FIELDS.}

I.

荡

Glad nature robes herself to meet the spring;

Hark, how the blithesome birds are making Among the trees their songs of weleoming!

$\mathrm{Oh}$, eome across the fields, my love, And throngh the woods with me; As nature mores toward the spring, So moves my heart to thee, my love, So moves my heart to thee!

Il.

See, from their silent shelters sweetly peeping, The budding wild-flowers steal with timid gleo 
See the soft fresh verdure, gently creeping,

Is mantling over the delighted lea!

Then come across the fields, my love, And through the woods with me; As nature moves toward the spring, So moves my heart to thee, my love, So moves my heart to thee!

III.

Oh! listen, love; it is the throstle's carol,

In yonder elm-tree ringing loud and clear;"First come the buds, and then the bonny blossom-

The golden summer time will soon be here !" Then come across the fields, my love, And through the woods with me; As nature moves toward the spring, So moves my heart to thee, my love, So moves my heart to thee! 
IV.

My heart is like a flowerless wintry wild, Where tuneless joy sits lone, with folded wing, Until thy beauty comes, enchantress mild, To melt the gloom, and make the flowers spring ! Oh, shine upon this longing heart, And I thy charms will sing, For thy sweet re-appearing Is like another spring, my love, Is like another spring!

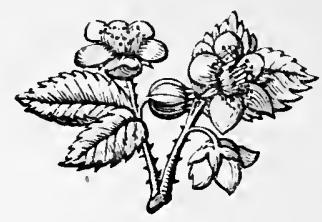




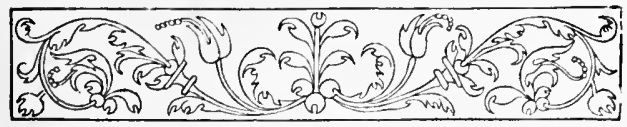

\section{OH! WEAVF A GARLAND FOR}

\section{MY BROW.}

I.

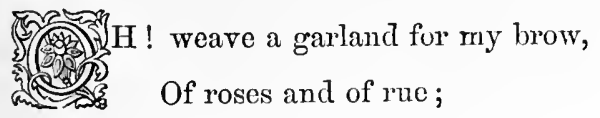

For once I loved a bonny lass,-Alas, she was not true!

But when she slighted all my grief,

I knew that grief was vain, And I hid the wound that pained my heart, Until it healed again. 
II.

Then, gentle lover, pine no more,-

Thy tenderness is blind;

Sighing to one whose heart is cold

Will nerer make her kind.

Go, take some comfort to thy breast-

The world is fair to see-

And on some genial bosom rest

Whose pulses beat for thee.

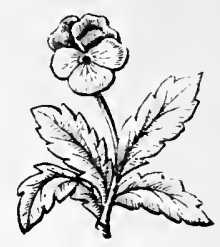




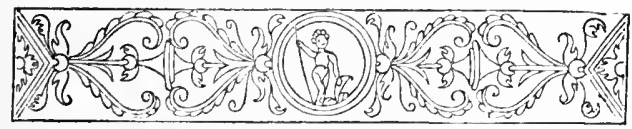

TO THE SPRING WIND.

I.

WEET minstrel of the scented spring,

Ten thousand silver bells,

To welcome thee, are all a-swing,

Upon the dewy fells:

To sing with thee, I should be fain,

Thou harper blithe and free!

But love has bound me with a chain,

That wrings the heart of me.

II.

$\mathrm{Oh}$, hasten to my love, and tell

Her how she makes me pine;

And ask her if she thinks it well

To slight a heart liko mine ; 
For if my suit her scom doth move,

It shall no longer be,-

Although I know she 's made for love,

And I wish that she loved me.

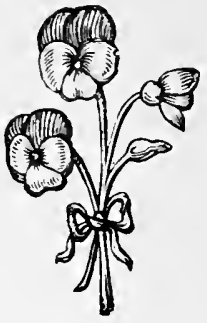




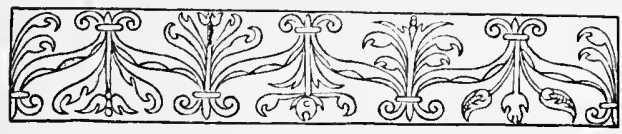

\section{NIGHTFALL.}

I.

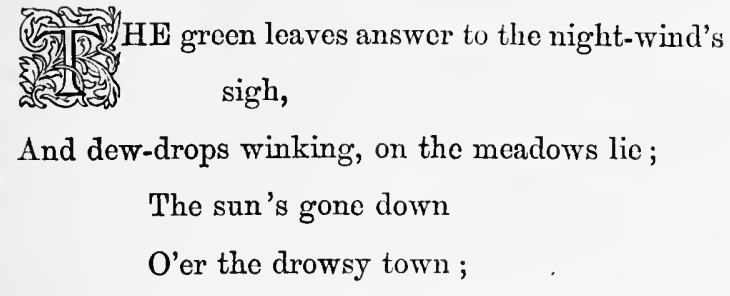

And the brooks are singing to the listening moon.

II.

The soft wind whispers on its moody way;

The plumy woodlands in the moonlight play;

Night's tapers gleam

In the gliding stream;

Hearen's eyes are watching while the earth doth dream. 
III.

The lovely light that dwells in woman's eyes,

Softly curtained by the fringed lids lies;

Sleep's Lethean hand

Waves o'er the land,

And the weary toiler to his shelter hies.

IV.

Old nurse, whose Inllaby'can soothe them all, Oh, hap them kindly in thy downy pall!

They've gone astray

On life's rough way;

But, rest them; rest them for another day.

จ.

The living, sleeping in their warm beds lie;

The dead are sleeping in the churehyard, nigh ;

The mild moon's beam

O'er all doth stream,

And life and death appear a mingling dream. 
VI.

Decay, that in my very breath doth creep,

Thou surely art akin to this soft sleep,

That shows the way

To a bed of clay,

Whose wakeless slumbers close the mortal day.

VII.

And thus, with ceaseless roll, time's silent wave Lands me each night upon a mimic grave,

Whose soft repose

Hints at life's close,-

Death's fleets are cruising where life's current flows. 


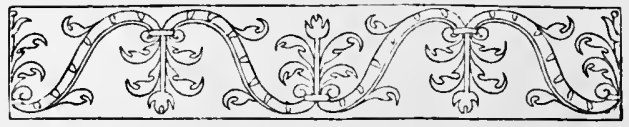

TO A YOUNG LADY,

WHO LENT ME AN OLD BOOK.

I.

1

A story so divine,

Nor point a moral half so well

As that young face of thine.

II.

Thou shouldst have sent a rose to me,

With morning dew bestarred;

It would have better likened thee,-

Sweet rosebud of the bard! 
III.

But mornings fly, and dewdrops dry, And many a lovely rose

Is plucked, and thrown neglected by, Before it fairly blows.

IV.

Sweet maid, thy budding time is fair;

So may thy blooming be;

And never blighting blast of care

Untimely wither thec.

v.

Flower on, in gladness, free from stain,

Until the autumn's past;

And, like a fading rose, retain

Thy sweetness to the last. 


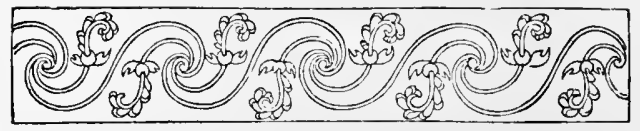

POOR TRAVELLERS ALL.

I.

ONen travellers all,

How thonghtlessly we play

In a country

Of mortality,

Where never a man can stay.

II.

Our birth is but

A starting foot

Upon the fatal road, 
Where death kceps watch

O'er life, to suatch

The jewel back to God.

III.

Time's sickle reaps,

In restless sweeps,

The harvest of decay;

On every ground

His sheaves are bound, And garmered in the clay.

IV.

Though hints divine,

In symbols fine,

With warnings strew the way,--

Beseeching us,

And teaching us,

The danger of delay,- 
v.

We dally still,

With fitful will,

Among delusive joys ;

Heeding them not,

Except for sport,-

As children play with toys.

VI.

We romp and run

Mad in the sun;

We murmur at the cloud;

And where's the breast

That's quite at rest

Until it's in a shrond?

VII.

Thus glides away

Life's little day,

In giddiness and glooms;

$\mathrm{r}$ 
And never a one

Can feel it's gone,

Until his bed-time comes.

VIII.

Poor travellers all,

Both great and small,

How thoughtlessly we play,

In a country

Of mortality,

Where never a man can stay.

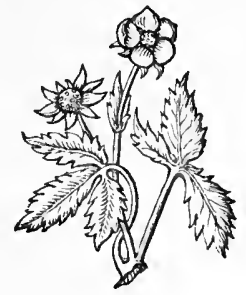




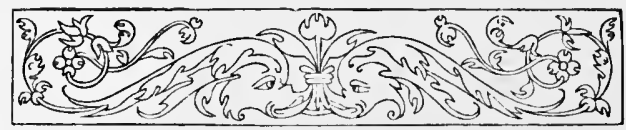

THE DYING ROSE.

I.

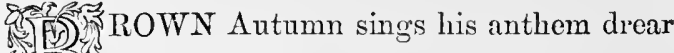

O'er Summer's waning pride;

And the water-lily to its bier

Droops by the brooklet side:

The hour has come, my floral gem,

That beckons thee away,

To join these relies of the bower,

In neighbourly decay.

II.

I saw thy bud, with orient tip,

Peep forth in beauty rare;

I saw the dewdrops throrig thy lip-

Thou sweetheart of the air ! 
But brief, alas, the eharm it wrought In this delighted eye;

For, 'twas unmingled with a thonght That thou wert doomed to die.

III.

The golden sunshire smiled to sce How beautiful thou grew; Rich with thy perfume, o'er the lea The whispering breezes flew;

The wild bee well might linger long Within thy rosy folds, 'Twas there he purchased, for a song, The sweetest wealth he holds.

IV.

But Summer's golden glory's o'er ;

All nature seems to moan :

Both leaf and flower have had their hour, And home again are gone; 
The greenwood's tresses, fallen away,

Upon the ground are laid:

And chill winds in the sear leaves play

The requiem of the dead.

V.

Not long, at best, oh fading flower,

Has man to stay behind;

Cold deatl may still at any hour

The fever of his mind;

May check his frets of joy and grief,

Extinguish all his pride,

And lay lim, like a blighted leaf,

To moulder at thy side.

VI.

But go thy way; 'twas ever so

With what's beneath the sky;

We do not all so sweetly grow,

But, we as surely die: 
Companions, in a graveward throng, Upon a rugged way,

Where trouble cannot keep us long, Though joy doth never stay.

VII.

Go, rest in peace thy weary head,

Death's silent winter through ;

New spring shall eheer thy lonely bed, And wake thy life anew:

So thou, my soul, shalt rise again, To breathe a purer breath, In elimes beyond the fatal chain That binds this realm of death. 


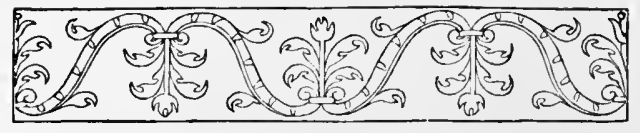

\section{LINES.}

If fortune delight thee,

Beware its alloy;

And should it despite thee,

Endure it with joy.

For, to win its caressing 's

A dangerous gain;

And Heaven's best blessings

Are hidden in pain. 
While youth and health bless thee, Remember the day

When mourners shall dress thee To sleep in the clay.

Do good unto all men, Contented, unknown; Expecting thy payment From Heaven alone.

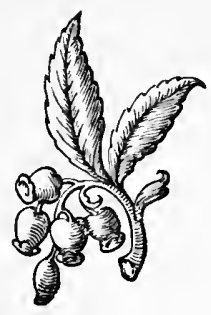




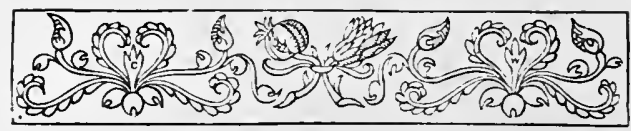

THE MAN OF THE TIME.

I.

$\mathrm{E}$ is a sterling nobleman

Who lives the truth he knows;

Who dreads the slarery of sin,

And fears no other foes.

II.

Who scorns the folly of pretence;

Whose mind from cant is free;

Who values men for worth and sense,

And hates hypocrisy. 
III.

Who glows with love that's free from taint;

Whose heart is kind and brave;

Who feels that he was neither meant

For tyrant nor for slave.

IV.

Who loves the ground, where'er he roam,

That's trod by human feet,

And strives to make the world a home

Where peace and justice meet.

v.

Whose soul to clearer heights can climb,

Above the shows of things,-

Cleaving the mortal bounds of time,

On meditative wings, 
FI.

Malice can never mar his fame;

A heaven-crowned king is he;

His robe, a pure immortal aim;

His throne, eternity.

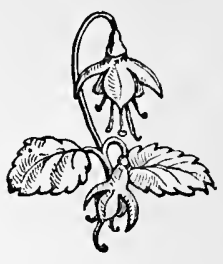




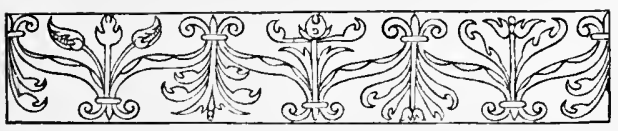

THE WANDERER'S HYMN.

I.

APPY the heart that's simply pure;
Happy the heart that's nobly brave;

Happy the man that breaks the lure

That winds like death round folly's slave.

II.

Wandering in the worldly throng,

The dust of earth still keeps us blind;

The judgment's weak, the passions strong,

The will as fitful as the wind. 
III.

Disguised in joy's deceitful beams,

A thousand fitful meteors ply

About our path the demon-schemes, That dazzle only to destroy.

IT.

Who can we ask for aid but Thee, Our only friend, our only guide?

What other counsellor hare we?

Where else, oh, where, can we abide?

r.

Oh! hear and help us while we pray;

And travel with us all the way!

Oh! hold our hands, and be our stay!

$\mathrm{Oh}$ ! set us right whene'er we stray! 


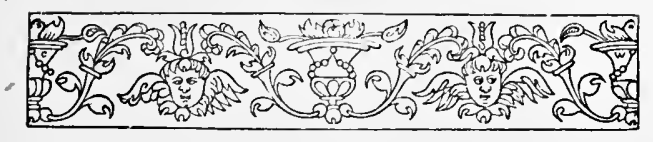

\section{ALONE, UPON THE FLOWERY PLAIN.}

I.

穴

(3)

I rove, in solitary pain;

Looking around the silent lea

For something I shall never see.

II.

Yon hedge-row blossoms as before,

And roses shade yon cottage door;

But oh, I miss the tresses fair,

And eyes that glowed with weleome there. 
ALONE, UPON THE FLOWERY PLAIN. 119

III.

The streamlet, still, in rippling pranks,

Kisses the wild flower on its banks;

But I am lonely on the shore,

To which my lore returns no more.

IV.

The lark, aloft in sunny air,

Carols, as if my love was there;

And the wind goes by, with mournful sound,

Marmuring, "No more, on mortal ground." 


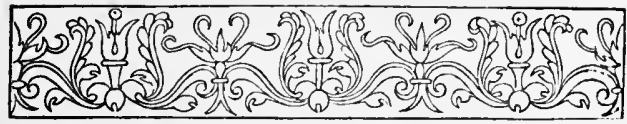

LIFE'S TWILIGHT.

I.

(6)

㒸

Among my thinning hair;

And down the slope of life's decline

I thoughtfully repair.

The fire that once was in mine eyes

Has dimmed its fervid ray,

And every hour of life that flies,

Is stealing light away.

$\mathrm{Oh}$, let me, with untroubled breast,

A while in shadow lie,

Before I lay me doẉn to rest,

And bid the world "Grood byc." 
II.

With Time, that wrestler old and grim,

I've had a gallant round;

But ah, there's little chance with him

Who bringeth all to ground.

Although the world still rolleth on

Its merry, motley way,

My little part of life is done,

Except to watch the play.

Then, let me, with untroubled breast,

A while in shadow lie,

Before I lay me down to rest,

And bid the world "Good bye."

III.

In youth, to pleasure's lightest trill, My heart leaped blithe and free;

Now, she may play what tune she will.

It is not so with mo; 
For though a smile may sometimes steal Across my furrowed brow,

My joys are all akin, I feel, To contemplation now. Then, let me, with untroubled breast, A while in shadow lie, Before I lay me down to rest, And bid the world "Good bye."

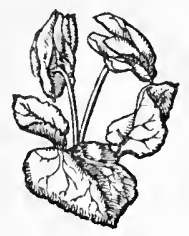




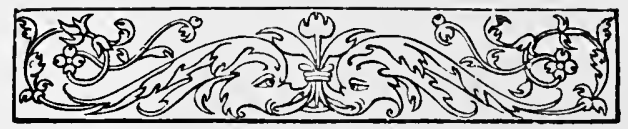

CHRISTMAS MORNING.

I.

POE all you weary wanderers, s.

Beneath the wintry sky;

This day forget your worldly eares,

And lay your sorrows by;

Awake, and sing ;

The church bells ring;

For this is Christmas morning:

II.

With grateful hearts salute the morn,

And swell the streams of song,

'That laden with great joy are borne,

The willing air along; 
The tidings thrill

With right good will;

For this is Christmas morning!

III.

We 'll twine the fresh green holly wreath, And make the yule-log glow; And gather gaily underneath The winking misletoe;

All blithe and bright

By the glad fire-light;

For this is Christmas morning !

IV.

Come, sing the carols old and true,

That mind us of good cheer, And, like a heavenly fall of dew, Revive the drooping year;

And fill us up

A wassail-cup;

For this is Christmas morning! 
v.

To all poor souls we'll strew the feast,

With kindly heart, and free;

One Father owns us, and, at least,

To-day we 'll brothers be;

Away witl pride,

This holy tide;

For it is Clnistmas morning !

VI.

So now, God bless us one and all

With hearts and hearthstones warm;

And may He prosper great and small,

And keep us out of harm ;

And teach us still,

His sweet good-will,

This merry Christmas morning! 


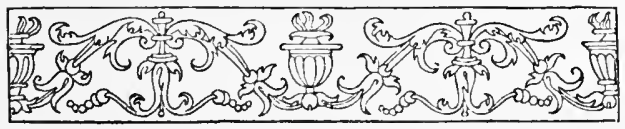

SONG.

I. .

(4) $\mathrm{T}$ the close of day, her melting lay As Philomel began,

A maiden sang as she did stray,

And thus the carol ran :

II.

$\mathrm{Oh}$, the daisy, and the sweet bluebell, And the bonny celandine;

My darling's feet have touched the dell, And made the posies fine. 
III.

Soft whispering gales, on viewless wings,

Come o'er the rippling sea;

But ah, no news the west wind brings

From my true love to me.

IV.

The wild bee roves the flowery wold;

Be still, dear heart of mine ;

My darling is a cup of gold

That's running o'er with wine.

v.

Sweet bird, whose tender warble fills

The ear of fading day,

Go, sing for me those liquid trills,

That fond complaining lay. 


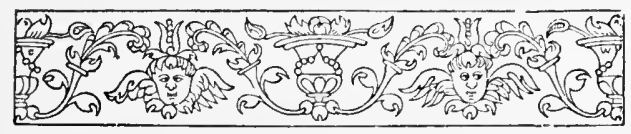

THE WOUNDED LARK.

WRITTEN ON THE ILLNESS OF AN EMINENT MUSICIAN.

I.

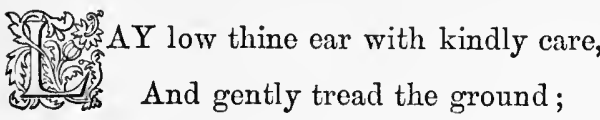

Some mourner haunts the grassy lair;

What means this plaintive sound?

II.

Here, 'mongst his little nestlings, lies

A lark, with broken wing,

Gazing aloft into the skies,

Where once he used to sing. 
III.

No more, up-springing from the lawn,

To greet the brightening sky,

High-poised, 'mid rosy tints of dawn,

He'll thrill the world with joy.

IV.

No more above the sun-tipt hills

He'll fan his happy wings ;

His notes have sunk to mournful trills,

And sorrow's all he sings.

$\nabla$.

So prone lies he, whose genial power

Once led the tuneful train;

So fate has changed his joyous lower

To cadences of pain. 
VI.

Thus, daily, minstrel tones do creep

In sadness, one by one,

Into the silent land, where sleep

The voices that are gone.

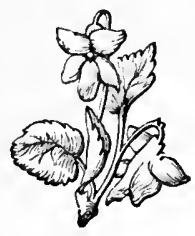




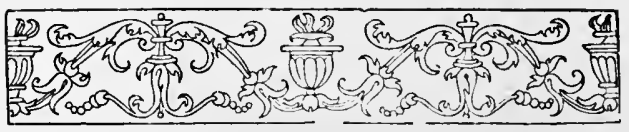

SEA WEEDS.

I.

(अ)

Its flowers of every hue,

Which close as the daylight eloses,

And wake to the morning dew ;

It has sweet-scented groves of pleasure,

Where the bee roves all day long,

And, at eve, with her load of trensure,

Flies home to a drowsy song.

II.

There, summer her mantle of verdure,

With posies so sweet enweares, 
That the sunshine delays on their beauty, Till it falls asleep in the leaves; And the spell-bound rain comes dreeping, To brighten their eyes anew; And their folds are by young winds fondled, And kist by the silvery dew.

III.

But the grand old sea hides wonders That never met mortal eyc,Bright bowers that never have rustled To soft wind's dreamy sigh;

Strange groves of mystical beauty, And flowers of rainbow hue, Bloom wild in those old sea-gardens, All under the waters blue!

IV.

And when the pale moon is slecping, At night, on the trembling sca, 
And the coral-paved halls of Neptune

Re-echo the kelpies' glec :

$\mathrm{Ol}$, the floral festoons of magie,

That curtain those pearly caves,

Where the water-sprites revel in splendour,

All under the drowsy waves!

v.

Ye fairy-tinged groves of ocean,-

Your delicate banners wave,

Where the fisherman slecps in the lonely deeps,

In his cold, unerowded grave:

Ware on your beautiful tendrils,

In your gardens wild and frec,

Caressed by the gleaming waters,

Of the grand old heaving sea! 


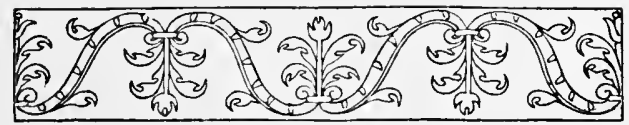

\section{THINGS GONE BY.}

I.

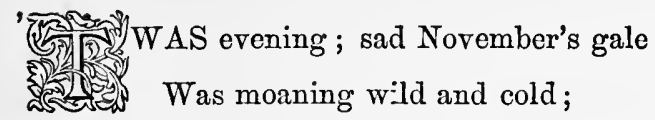

Night's deep'ning shade had dimm'd the vale, And hid the distant wold;

In dreamy mood, as all grew still

Beneath the waning sky,

I sat beside my window-sill,

And thought of things gone by.

II.

An old and lonely man was there,

By labour sorely worn; 
The frost of age had thinn'd his hair, And sorrow made him lorn; His wrinkled cheek long time had play'd With wind, and rain, and sun; That weary man, he sigh'd, and said': It's dark-and nothing done."

III.

On life, and death, and mortal fret,

I musing then began;

And on the dangers that beset

The pilgrimage of man :

I thought of days for ever flown, And hopes for erer fled;

I sigh'd for friends asunder throwr, Or sleeping with the dead.

IF.

Since life's first wand'ring step began They're strewn the fatal way, 
And only here and there a man Has reach'd the close of day;

Like leaflets, drifted to and fro, When autumn's cold winds rave, Some fluttering wild, some trampled low, Some mould'ring in the grave.

v.

The days are gone when, light and free,

I roved the mountains wild;

The light no more will shine for me

On morning's hour that smiled:

No sun or rain can e'er again Revive youth's faded flowers ;

No sad regret, nor sigh of pain, Recall the fleeted hours.

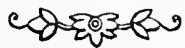




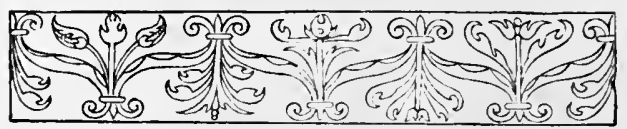

\section{MINNIE.}

I.

blows;
Its leaves, pleasant-scented,
Unfolding, eontented
To sweeten the nook where it grows.

II.

Kate flutters her wings, and a lady would be;

She's ribboned, and jewelled, and flounced to the knee ; 
But she's keen, and she's cold, And she's proud of her gold,The dule take her ribbons, for me!

III.

My Minnie's as poor as a little red-breast,

"With nought in the wide world but God and its nest;"

Yet the star of a king

Is a pitiful thing

To the jewel that glows in her breast.

IV.

Kate's handsome and bold, and she's haughty and chill ;

She's a winterly smile for the heart she can kill;

And she bears off the bell

From the girls of the dell,-

With a clapper that never lies still. 
v.

Though Minnie's as blithe as the skylitrk that springs

From its roost in the meadow, with dew on its wings-

'Tis her own little nest,

And the mate she loves best,

That gladden the song that she sings.

VI.

What care I for riches, and gaudy array--

What care I to flaunt with the heartlessly gay?

If my little wild-rose

Love me on to life's close,

And sweeten its troublesome way. 


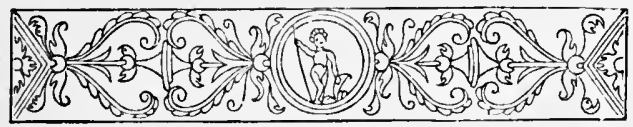

THE MOORLAND MAID.

I.

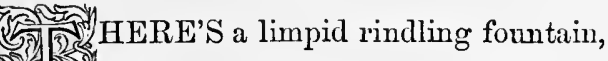
1) 1 .

Yonder moorland hills among;

From the heather-breasted mountain

Tinkling drips its liquid song;

To its lonely music list'ning,

Once a maiden sat thereby;

Oh, that maiden's dar'k eye glist'ning--

It will haunt me till I die.

II.

In that fragrant, wild seclusion,

With the soaring lark above, 
Blooming nature's glad profusion

Listen'd to our vows of lore :

Sunny skies, and flow'rs around us,

On my rustic darling smiled;

And the dewy twilight found us

Ling'ring still amid the wild.

III.

Oh, mild hour, when eve's lone planet

Gilds the pearls on every blade;

Angel-zephyrs came to fan it-

Blissful hour of mystic shade;

Sweet the wild-birds's trilling vesper's

Died upon the dewy lea;

But my darling's gentle whispers

Never more will fade from me.

IT.

Ah, that scene is now too sadd'ning- -

Saddest in its richest bloom ; 
Summer flowers, the wild hills gladd'ning, Move my heart to deeper gloom;

Birds may hail the scented blossom Oft on smiling hill and plain,

But the green earth's silent bosom Ne'er will yield my love again.

$$
\text { v. }
$$

Thus to meet thee, but to sever;

Thus to love, and then to part-

$\mathrm{Oh}$, the bliss, the pain, for ever

Mingling in my lonely heart :

$\mathrm{Oh}$, those lovely glances, darting

Modest gleams of timid glee;

Oh, the last sad hour of parting,

'Tween my own true love and me.

VI.

Farewell to yon breezy mountain;

Farewell to the flow'ry dell; 
Farewell to the rindling fountain, And the lonely moorland well ; Farewell to the streamlet, purling Sweetly through 5on silent glen; Oh, farewell, the dark-ejed darling I shall never see again!

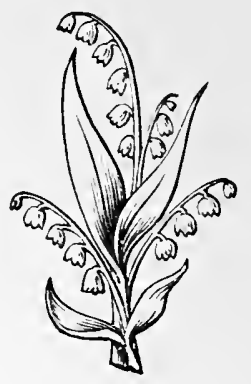




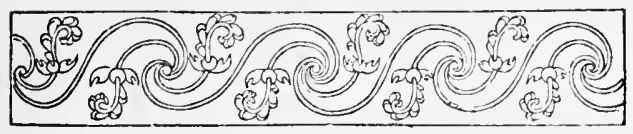

PROLOGUE

(WRITTEN ON THE OCCASION OF THE MANCIIESTER

LETTERPRESS PRINTERS' DRAMATIC ENTERTAIN-

MENT, APRIL 4TH, 1868.)

HEN first, from old Westminster's hoary (a) pile,

The Art of Printing dawned on Britain's isle,

In some dim chapel of that sacred faue

The venerable Caxton ruled his train,-

Whose artful toil, foredoomed by mystic tie,

Flushed the young stream of England's liberty.

England! where noble hearts had wrestled long,

In dumb contention bctween right and wrong, 
'Twas there in cloistered shade, he wove the spell At whose behest the chain of silence fell ; And, nursing skill, with strange mutations fraught, Gave freedom to the prisoned realms of thought !

Strange were the implements, the labour strange;

The little rill of art was big with change;

With loving care, the initiated few

There, brought the infant mystery to riew;

And, as in dim secluded gloom they toiled,

Fate's folded skein of printed thought uncoiled;

Whilst the hushed murmurs of the working throng

Mingled with solemn strains of sacred song:

There learned churchmen pondered in amaze, And kingly patrons dealt bewildered praise : $\mathrm{Ah}$, little dreamt they what that germ contained,-

What vast, upheaving powers, heaven-ordained! 
Rude were the artist's tools, the product slight;

Costly and few the works it brought to light;

Mysterious came the first imprinted page,

To th' wondering gaze of an unletter'd age;

And small the induccment such an art to ply,

When only clerks could read, and only kings could buy.

But time,- the soil of life's eventful field-

Was doomed, by fate, the mighty plant to yield;

Doomed to sustain, and nurture, through the night

Of undergrowth, until it burst to sight, And cheered the nations with its presence bright! Slow grew the art-though often checked,--it grew;

Now, nipt with frost, now fed with rain and dew ;

Slow grew the struggling art, but still, it grew.

In patient majesty, the nursling rose; 
Rooted by struggle, and made strong by blows;

Till e'en its nurses watched it with surprise,

And tyrants trembled as they saw it rise !

For, as it grew, to realms of light it led,

And fed the freedom upon which it fed.

Oh, freedom! Spark of heaven-descended fire,

'That never fades from noble heart's desire!

The bird that in the wild wood carols free-

No bird, imprisoned, sings so well as he!

Thanks to those lofty stars of England's night,

Who cheered her struggling sons with steadfast

light!

Thanks to the men who fought and suffered long,

To make the right triumphant over wrong!

Thanks to those gallant hearts of later breed,

By whom the Press was from its trammels freed,-

Now, thousands print what millions rush to read! 
But stay, my roving muse,-restrain thy flight What is it brings the Press-gang here to-night? Come they, as erst, somc wandering slave to seize?

$\mathrm{Ah}$, no,-our mission is to free, and please:

In mutual self-reliance to combine, To soothe the last sad hours of life's decline;

To help the feeble and to cheer the sad;

The worn-out workman's sinking heart to glad;

From bitter penury the sick to save,

And smooth the totterer's way unto the grave.

And feeble, though, our histrionic skill,

It humbly seeks to lessen human ill.

Then, oh, with generous hearts, give kind acclaim,

And cheer the labour for its noble aim.

Oh, Printing, Art with mystic power fraught! Thou swift dispenser of undying thought! Strew lofty lessons still, at heaven's behest: 
And teach us Charity above the rest !

And, till we're summoned hence, by fatal call,-

Father of Nature's Chapel, ${ }^{1}$ bless us all !

In the old printing-offices of England, and even in many of the best printing-offices of the kingdom now, the workmen form a little court of law, summoned occasionally for the settlement of disputes among themselves. This court they call "The Chapel," and the President of the court is called "The Father of the Chapel." Doubtless these names arise from the fact that the first English printing-office was one of the chapels of Westminster Abbey.

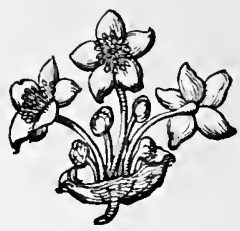





\section{MC.c.

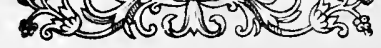

\section{SONGS IN THE LANCASHIRE \\ DIALECT.}

$\$$ 



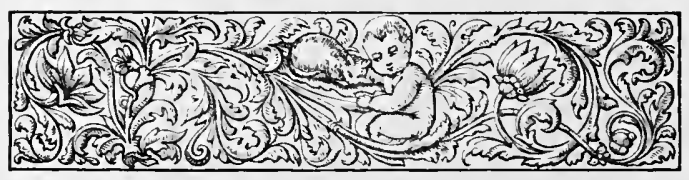

SONGS.

COME WHOAM TO THY CHILDER

AN' ME.

I.

IV 'VE just mended th' fire wi' a cob;' Owd Swaddle has brought thi new 20203

shoon ;

There's some nice bacon-eollops o'th hob, An' a quart o' ale posset i'th oon ; $^{2}$ Aw've brought thi top-ewot, ${ }^{3}$ doesto know,

For th' rain's comin' deawn very dree ;

1 Cob, a lump of coal.

Top-cuot, top-coat.
$2 \mathrm{Om}$, ovelt.

4 Dree, wearily-continuous. 
An' th' har'stone's as white as now snow;-

Come whoam to thi ehilder an' me.

II.

When aw put little Sally to bed,

Hoo cried, 'cose her feyther ${ }^{1}$ weren't thecr,

So aw kiss'd th' little thing, an' aw said

Thae'd bring her a ribbin fro' th' fair ;

An' aw gav her her doll, an' some rags,

An' a nice little white cotton-bo';

An' aw kiss'd her again; but hoo said

'At hoo wanted to kiss thee an' o'.

III.

An' Dick, too, aw 'd sich wark ${ }^{2}$ wi' him,

Afore aw could get him up stairs;

1 Feyther, father.

2 Warh, work. 
Thao towd him thae'd bring him a drum, He said, when he're sayin' his prayers; Then he looked i' my face, an' he said, "Has th' boggarts taen houd o' my dad?" An' he cried whol ${ }^{1}$ his een were quite red; He likes thee some weel, does yon lad!

\section{IV.}

At th' lung-length, ${ }^{2}$ aw geet him laid still;

An' aw hearken't folks' feet 'at went by ;

So aw iron't o' my clooas reet weel, An' aw hanged 'em o'th maiden to dry; When aw'd mended thi stockin's an' shirts, Aw sit deawn to knit i' my cheer, An' aw rayley did feel rayther hurtMon, aw'm one-ly ${ }^{3}$ when thear artn't theer.

1 Whol, while, until.

2 Th' lung-length, the lcng-length:, the end.

3 One-ly, lonely. 
156 COME WHOAM TO THY CHILDER AN' ME.

r.

"Aw 've a drum an' a trumpet for Dick; Aw've a yard o' blue ribbin for' Sal ; Aw've a book full o' babs ; ${ }^{1}$ an' a stick An' some bacco an' pipes for mysel'; Aw've brought thee some coffee an' tayIv thae'll feel i' my pocket, thae'll see; An' aw've bought tho a new cap to-day,-

But aw olez ${ }^{2}$ bring summat for thee!

VI.

"God bless tho', my lass ; aw'll go whoam, ${ }^{3}$ An' aw'll kiss thee an' th' childer o' reawnd:

Thae knows, that wheerever aw roam, Aw'm fain to get back to th' owd greawnd; Aw can do wi' a crack o'er a glass; Aw can do wi' a bit ov a spree; But aw've no gradely ${ }^{4}$ comfort, my lass, Except wi' yon childer and thee."

I Babs, babies, pictures. 2 Olez, always.

3 IIhoam, home. 4 Gradely, proper, right. 


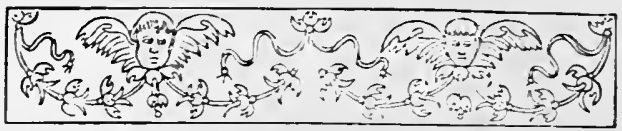

WHAT AILS THEE, IIY SON ROBIN?

1.

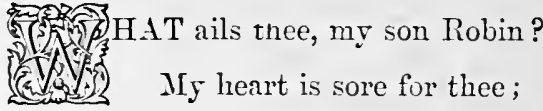

Thi cheeks are grooin' thinner, An' th' leet has laft thi e'e ;

Theaw trails abeawt so lonesome, An' looks so pale at morn;

God bless tho, lad, aw'm soory ${ }^{2}$

To see tho so forlorn.

1 Th' leet has laft thi e'e, the light has left thine eye.

2 Soory, sorry. 
IT.

Thi fuutstep's sadly awter't. ${ }^{1}$

Aw used to know it weel,-

Neaw, arto fairy-stricken, lad;

Or, arto gradely ${ }^{2}$ ill ?

Or, hasto bin wi' th' witches

I'th cloof, ${ }^{3}$ at deep o'th neet?

Come, tell mo, Robin, tell mo,-

For summat is not reet!

III.

" Eh, mother, dunnut fret yo;

Aw am not like mysel';

But, 'tisn't lung o'th feeorin'

That han to do wi' th' deil;

There's nought 'at thus could daunt mo,

I'th cloof, by neet nor day;-

1 Awter't, altered.

2 Gradely, properly, thoroughly.

3 Cloof, clough, glen.

- Feeorin', frightening, things that frighten. 
It's yon blue cen o' Mary's;-

They taen my life away."

IV.

"Aw deawt 1 aw've done wi comfort

To th' day that aw mun dee,

For th' place hoo sets her fuut on,

It's fairy greawnd ${ }^{2}$ to me ;

But, oh, it's no use speykin',

Aw connut ston her pride;

An' when a true heart's breykin'

It's very hard to bide!"

v.

Neaw, God be wi' tho, Robin ;

Just let her have her way;

$1 A w$ deawt, I doubt, I think, I surnise.

2 Fairy-greawnd, enchanted ground. 
160 WHAT AILS TIIEE, MY SON ROBIN?

Hoo'll never meet thy marrow, ${ }^{1}$

For mony a summer day;

Aw're just same wi' thi feyther,?

When first he spoke to me:

So, go thi ways, an' whistle;

An' th' lass'll come to thee !

1 Marrow, match. $\quad 2$ Feyther, father.

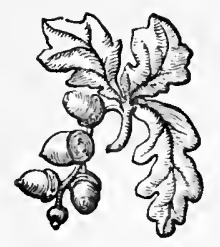




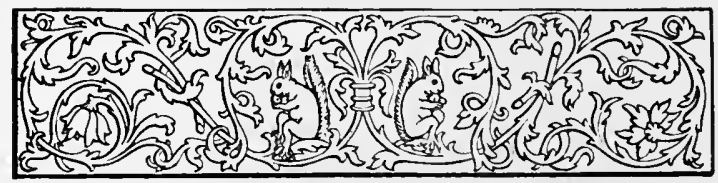

\section{WILLY'S GRATE.}

1.

HE wintry wind was wailing wild,

Across the moorland wold;

The cloudless vault of hearen was bright

With studs of gleaming gold;

The weary cotter's heary lids

Had closed with closing das;

And, on his silent hearth, a tinge

Of dying firc-light lay. 
162

WILLY'S GRAVE.

II.

The ancient village scemed asleep

Beneath the starry sky;

A little river, sheathed in ice,

Came gliding gently by ;

The grey church, in the grave-yard, Where " the rude forefathers lay,"

Stood, like a mother, waiting till

Her children came from play.

III.

No footstep trod the tiny town;

The drowsy street was still;

Save where the wandering night-wind sang

Its requiem wild and shrill :

The stainless snow lay thick upon

Those quaint old cottage eaves;

And wreaths of fairy frost-work hung

Where grew last summer's leaves. 
IV.

Each village home was dark and still,

And closed was every door;

For gentle sleep had twined her arms

Around both rich and poor,-

Save in one little cot, where, by

A candle's flickering ray

A childless mother sighing sat,

And combed her locks of grey.

v.

Her husband, and her children all, Were in the silent bed,

Where, one by one, she'd laid them down-

And left them with the dead;

Then, toiling on towards her rest,-

A lonely pilgrim, she,-

For God and poverty were, now,

Her only company. 
VI.

Upon the shady window-sill,

A well-worn bible lay;

Against the wall, a coat had hung,

For many a weary day ;

And, on the scanty table-top,

With crumbs of supper strewn,

There stood, beside a porringer,

Two little empty shoon.

VII.

The fire was waning in the grate;

The spinning-wheel at rest;

The cricket's song rang loudly in

That lonely worman's nest ;

As, with a napkin, thin, and worn,

And wet with many a tear,

She wiped the little pair of shoon

Her darling used to wear. 
VIII.

Her widowed heart liad often leaped

To hear his prattle small;

He was the last that she had left-

The dearest of them all;

And, as she rocked her to and fro,

While tears came dreeping down,

She sighed, and cried, "Oh, Willy, love,-

These little empty shoon!"

IX.

With gentle hand she laid them by,-

She laid them by with care;

For, Willy, he was in his grave,-

And all her thoughts were there:

She paused before she dropped the sneck,

That closed her lambless fold,-

It grieved her heart to bar the door,

And leare him in the cold. 
x.

A thread-bare cloak she lapped around

Her limbs, so thin and chill;

She left her lonely cot behind,

While all the world was still;

And through the solitary night,

She took her silent was,

With weeping eyes, towards the spot

Where little Willy lay.

XI.

The pallid moon had climbed aloft

Into the welkin blue;

A snow-clad tree across the grave

Its leafless shadow threw;

And, as that mournful mother sat

Upon a mound thereby,

The bitter wind of winter sighed

To hear her lonely cry!

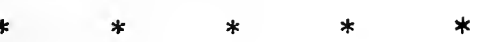


III.

My little Wills's cowd an' still,-

He's not a cheep for me:

Th' last tremblin' leaf has dropt awa!

Fro' this poor withered tree :

God help my heart: my comfort's gone!

I 'm lonely under th' skr:

He 'll nerer clip my neck again,

An' tell me not to crs: :

xiII.

My darlin' lad! He's laid ï th dust!

My little Willy's dead :

An'o' that made me cling to life,

Lies in his frosty bed:

He's gone! He's gone: Mr poor bare necst!

Oh, what's this world to me:

My little lore! I 'm lonely neaw!

When mun I come to thee: 
XIV.

He 's crept into his last dark nook,

And laft me pinin' here!

An' never-moor his two blue e'en

For me mun twinkle clear!

He' 'll never say his prayers again

At his poor mammy's knee!

Oh, Willy, love! I'm lonely now ;

When mun I come to thee!

$\mathrm{XV}$.

The snow-clad yew-tree stirred with pain

To hear that plaintive cry;

The old church listened; and the spire

Kept pointing to the sky;

With kindlier touch, the frosty wind

Played in her lucks of grey;

And the queenly moon, upon her head,

Shone with a softened ray. 
XVI.

She rose to leave that lonely bed;

Her heart was grieving sore;

One step she took, and then, her tears

Fell faster than before:

She turned and gave another look,-

One lingering look she gave,-

Then, sighing, left him lying in

His little wintry grave.

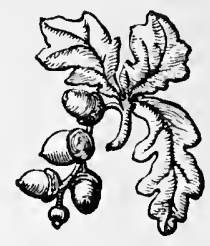




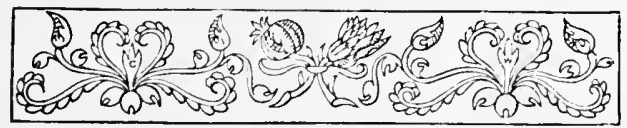

THE GRINDLESTONE.

Air_ "Derry Down."

I.

He're as fause as a boggart, as th' neighbours
weel knew,

Though,--when he'd a mind,-- he could look like a foo'.

Derry down.

II.

But th' bravest an' breetest o' th' childer o' men

May haply be hamper't a bit, now an' then;

Dody's axe wanted grindin', one wark-a-day morn, When there nobry about to gi' th' grindle a turn.

Derry down. 
III.

Then he grunted, an' mumble't, an' glendur't around, An' he tooted about o'er the neighbourin' ground ; Still, never a soul to turn th' stone eould he find, An' it made him a little bit thrutehed in his mind.

Derry down.

IV.

Till a soft lookin' urehin coom wanderin' by, Wi' his thumb in his mouth, an' a tear in his eje; Wi' his slate an' his satehel, he're ereepin' to schoo', An',-bi th' look of his een,-_Dody know'd he're a foo'.

Derry down.

v.

"Bi th' maskins," says Dody, "I'm losen't at last !" An' he beekon't o' th' lad that wur wanderin' past! "Come hither, my tight little maister o' men!" Then he poo'd out a sixpence,-an' fobbed it again.

Derry down. 
VI.

“There's a grindlestone here-dosto think thou can turn ;

If thou doesn't know how, I can help tho to larn. I connot howd th' axe an' turn th' hondle mysel'; Thou'rt a nice lad o' somebry's-come, give us a twell !"

Derry down.

VII.

Th' lad laid howd o' th' hondle, an' shap't like a mon;

For he lippen't o' sixpence, when th' turning wur done ;

So, he twirl't at this grindle o' Dody o' Joe's, Till saut-water trickl't off th' end of his nose.

Derry down.

VIII.

Dody felt at his axe,-an' he said, "Thou young foo';

Thou'lt get a rare twiltin' for stoppin' fro' schoo'; 
Hie tho' off, like a red-shank, or th' dur may bo teen'd:"

An' he gav' him a bit of a lifter beheend.

Derry down.

IX.

Th' lad dried fro his for-yed the breet briny drip; An' he pike'd up his books, wi' a wimperin' lip ; An' he crope off to schoo', turnin' o'er in his mind Th' first lesson he'd larn't i' the pranks o' monkind. Derry down.

$\mathrm{x}$.

As yo wander'n through life, ten 'at one that yo'n find

$A$ good lot o' folk that han axes to grind;

Give a turn when yo con; but remember to th' end, It's turnin' th' wrang road to turn on a friend.

Derry down. 


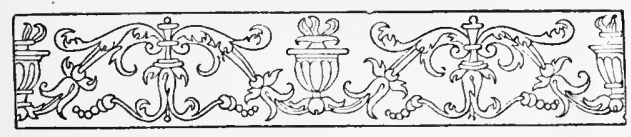

\section{GOD BLESS THESE POOR FOLK!}

1.

isg of $O D$ bless these poor folk that are strivin'

Crists By means that are honest an' true,

For some'at ${ }^{1}$ to keep 'em alive in

This world that we're scramblin' through :

As th' life or a mon's full o' feightin',?

A poor soul that wants to feight fair,

Should never be grudged ov his heytin', ${ }^{3}$

For th' hardest o'th battle's his share.

Chorus.-As th' life ov a mon.

1 Some'at, somewhat. $\quad 2$ Feightin', fighting.

3 Heytin eating. 
II.

This world's kin to trouble; i'th best on't,

There's mony sad changes come reawnd;

We wandern abeawt to find rest on't,

An' th' worm yammers ${ }^{1}$ for us i'th greawnd,

May he that'll wortch ${ }^{2}$ while he's able,

Be never long hungry nor dry ;

An' th' childer at sit at his table,-

God bless 'em wi' plenty, say I.

Chorus.--As th' life ov a mon.

III.

An' he that can feel it a pleasur'

To leeten misfortin an' pain,-

May his pantry be olez full measur':

To cut at, and come to again;

1 Yammer, to make an eager noise with the jaws, like hungry children at meal-time.

2 Wortch, work. 
176 GOD BLESS THESE POOR FOLK.

May God bless his cup and his cupbort, ${ }^{1}$

A theawsan' for one that he gives;

An' his heart be a bumper o' comfort,

To th' very last minute he lives !

Chorus.-As th' life ov a mon.

IV.

An' he that scorns ale to his victual,

Is welcome to let it alone;

There's some can be wise with a little,

An' some that are foolish wi' noan;

An' some are so quare i' their natur,

That nought wi' their stomachs agree;

But, he that would liefer ${ }^{2}$ drink wayter,

Shall never be stinted by me.

Chorus.-As th' life ov a mon.

1 Cupbort, cupboard.

2 Leifer, rather. 
$\nabla$.

One likes to see hearty folk wortchin', An' weary folk havin' a rest;

One likes to yer poor women singin'

To th' little things laid o' their breast:

Good cooks are my favourite doctors ;

Grood livers my parsons shall be; An' ony poor craytur at's clemmin, ${ }^{1}$ May come have a meawthful wi' me.

Chorus.-As th' life ov a mon.

VI.

Owd Time,- - he's a troublesome codger,-

Keeps nudgin' 2 us on to decay, An' whispers, "Yo're nobbut ${ }^{3}$ a lodger';

Get ready for goin' away;"

1 Clemmin, starving for want of food.

2 Nudgin', elbowing, jogrging, pushing.

3 Nobbut, nought but, only.

A A 
178 GOD BLESS THESE POOR FOLK.

Then let's ha' no skulkin' nor sniv'lin', Whatever misfortins befo';

God bless him that fends ${ }^{1}$ for his livin', An' houds up his yed ${ }^{2}$ through it o'!

Chorus.-As th' life ov a mon.

1 Fends, provides, works for.

2 Houds up his yed, holds up his head.

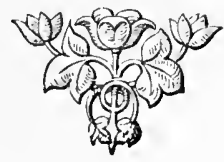




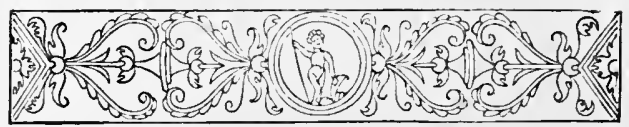

\section{COME, MARY, LINK THI ARII I' MINE.}

I.

Pro

8n' lilt away wi' me;

An' dry that little drop o' brine,

Fro' th' corner o' thi e'e ;

Th' mornin' dew i'th heather-bell's

A bonny bit o' weet;

That tear a different story tells,-

It pains my heart to sec't.

So, Mary, link thi arm i' mine.

II.

No lordly ho' o'th country-side's

So welcome to my view, 
As th' little corner where abides

My bonny lass an' true;

But there's a nook beside yon spring,-

An' iv theaw'll share't wi' me;

Aw'll buy tho th' bonny'st gowden ring

That ever theaw did see!

So, Mary, link thi arm i' mine.

III.

My feyther's gan mo forty peawnd,

I' silver an' i' gowd;

An' a pratty bit o' garden greawnd,

O' th' mornin' side ${ }^{1}$ o'th fowd;

An' a honsome bible, clen an' new,

To read for days to come;-

There's leaves for writin' names in, too,

Like th' owd un at's awhoam.

So, Mary, link thi arm i' mine.

1 Th' mornin' side, the east side, the side from which morning comes. 
IV.

Eawr Jenny's bin a-buyin' in, An' every day hoo brings

Knives an' forks, an' pots ; an' irous

For smoothin' caps an' things;

My gronny 's sent a chist ${ }^{1} o^{\text {' drawers, }}$

Sunday clooas to keep;

An' little Fanny's bought a glass

Where thee an' me can peep.

So, Mary, link thi arm i' mine.

v.

Eawr Tum has sent a bacon-flitch;

Eawr Jem a load o' coals ;

Eawr Charlie's bought some pickters, an'

He's hanged 'em upo' th' woles ;

Owd Posy's white-weshed th' cottage through :

Eawr Matty's made it sweet;

1 Chist, chest.

2 Iloles, walls. 
An Jack's gan me his Jarman flute,

To play bi th' fire at neet!

So, Mary, link thi arm i' mine.

VI.

There's cups an' saucers ; porritch-pons, ${ }^{1}$

An' tables, greyt an' smo';

There 's brushes, mugs, an' ladin'-cans ;

An eight-day's clock an' o';

There's a chcer ₹ for thee, an' one for me, An' one i' every nook;

Thi mother's has a cushion on't-

It 's th' nicest cheer i'th rook. ${ }^{3}$

So, Mary, link thi arm i' nine.

VII.

My gronny's gan me th' four-post bed, Wi' curtains to 't an' o';

- 1 Porritch-pons, porridge-pans. $\quad{ }^{2}$ Cheer, chair.

3 Rook, lot, collection, number. 
An' pillows, sheets, an' bowsters, too,

As white as driven snow;

It isn't stuffed wi' fither-deawn; ${ }^{1}$

But th' flocks are clen an' new ;

Hoo says there 's honest folk i'th teawn

That's made a warse un ${ }^{2}$ do.

So, Mary, link thi arm i' mine.

VIII.

Aw peeped into my cot last neet;

It made me hutchin' fäin ; ${ }^{3}$

A bonny fire were winkin' breet

I' every window-pane;

Aw marlocked ${ }^{5}$ upo' th' white bearth-stone.

$\mathrm{An}^{\prime}$ drummed o'th kettle lid;

1 Fither-deawn, the down of feathers.

2 A warse un, a worse one.

3 Hutchin' fain, fidgetting glad.

+ Brect, bright.

- Marlocked, frolicked. 
184 COME, MARY, LINK TIII ARYI I' MINE.

An' sung, "My neest ${ }^{1}$ is snug an' sweet;

Aw'll go and foteh my brid"!"

So, Mary, link thi arm i' mine.

Neest, nest. $\quad 2$ Fotch my brid, fetch my bird.

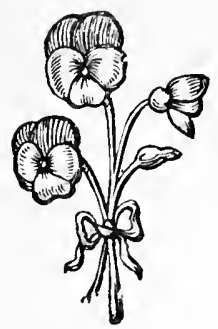




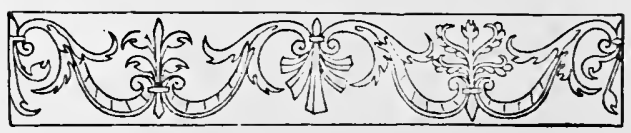

\section{chIRRUP.}

1.

modi ONG Chirrup wur a mettled cowt:

His heart an' limbs wur true;

At foot race, or at wrostlin'-beawt,

Or aught he buckled to;

At wark or play, reet gallantly

He laid into his game:

An' he're very fond o' singin'-brids ${ }^{2}$ -

That's heaw he geet his name.

1 A mettled cout, a spirited colt.

y Singin'-brids, singing-birds.

B B 
II.

He're straight as ony pickin'-rod,'

An' limber as a snig : ${ }^{2}$

An' th' heartiest cock o'th village clod,

At ony country rig:

His shinin' cen wur clear an' blue;

His face wur frank an' bowd;

An' th' yure abeawt his monly broo ${ }^{3}$

Wur crispt i' curls o' gowd.

III.

Young Chirrup donned his clinker't shoon, ${ }^{4}$

An' startin' off to th' fair,

He swore by th' leet o'th harvest moon,

He'd have a marlock ${ }^{5}$ there ;

I Pickin'-rod, the straight wooden rod with which hand-loom weavers pick, or throw the shuttle.

2 Limber as a snig, nimble as an eel.

= Th' yure abeawt his monly broo, the hair about his manly brow.

- Nonned his clinker't shoon, put on his strong shoes, nailed with the great nails known by the name of "clinkers."

s Marlock, a frolic. 
He poo'd a sprig fro th' hawthorn-tree, That blossomed by the way;"Iv ony mon says wrang' to me, Aw' 'll $\tan$ his hide to-day ",

IF.

Full sadly mony a lass would sigh, As wand'rin' slyly near, They tooted ${ }^{2}$ at his een to spy Iv love wur Iurkin' theer ;

So fair an' free he stept the green, An' trollin' eawt a song, Wi' leetsome heart, an' twinklin' een, Went chirrupin' along.

T.

Young Chirrup woo'd a village maid,An' hoo wur th' flower ov o',-

I Wrang, wrong.

2 Tooted, peeped carefully. 
Wi' kisses kind, i'th woodlan' sharle, An' whispers soft an' low ;

['Mally's ear twur th' sweetest chime That ever mortal sung;

An' Mally's heart beat merry time

To th' music ov his tung.

VI.

The kindest mates, this world within,

Mun sometimes meet wi' pain;

But, iv this pair could life begin,

They'd buckle to again;

For, though he're hearty, blunt, an' tough, An' Mally sweet an' mild,

For three.acore year, through smou.h an' rough, Hoo lad ${ }^{l}$ him like a child.

\footnotetext{
1 Lad, led.
} 


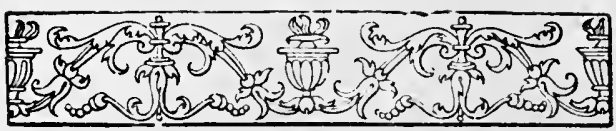

THE DULE'S I' THIS BONNET O' MINE.

1.

(-

E)

My ribbins 'll never be reet;

Here, Mally, aw'm like to be fine,

For Jamie 'll be comin' to-neet;

He met me i'th lone ${ }^{1}$ tother day,-

Aw're gooin' for wayter ${ }^{2}$ to th' well,-

An' he begged that aw'd wed him i' May ;-

$\mathrm{Bi}$ ' th mass, ${ }^{3}$ iv he 'll let me, aw will.

1 Lone, lane.

2 Hayter, water.

3 Bi'th mass, by the mass; an expression brought duwn from Catlrolic times. 
II.

When he took my two honds into his,

Good Lord, heaw they trembled between;

An' aw durstn't look up in his face,

Becose $^{1}$ on him seein' my e'en ;

My cheek went as red as a rose ; -

There's never a mortal can tell

Heaw happy aw felt; for, thea knows,

Aw couldn't ha' axed ${ }^{2}$ him mysel'.

III.

But th' tale wur at th' end o' my tung,-

To let it eawt wouldn't be reet,-

For aw thought to seem forrud ${ }^{3}$ wur wrong;

So aw towd him aw'd tell him to-neet;

But, Mally, thae knows very weel,-

Thongh it isn't a thing one should own,-

1 Becose, because. $\quad 2$ Axed, asked. $\quad 3$ Forrud, forward. 
If aw 'd th' pikein' ${ }^{1}$ o'th world to mysel', Aw'd oather' ${ }^{2}$ ha' Jamie or noan.

IV.

Neaw, Mally, aw'vo towd tho my mind; What wouldto do iv 'twar thee?

"Aw'd tak him just while he're inclined, An' a farrantly bargain ${ }^{3}$ he 'd be ;

For Jamie's as gradely ${ }^{4}$ a lad

As ever stept eawt into th' sun ;-

So, jump at thy chance, an' get wed, An' do th' best tho con, when it 's done !"

\section{$\nabla$.}

Eh, dear, but it's time to be gwon,--

Aw should'nt like Jamie to wait,-

Aw connut for shame be to soon, An' aw wouldn't for th' world be to late;

1 Pikein', picking, choosing.

2 Outher, either.

- A farrantly bargain, a decent bargain, a good bargain.

- Gradely, proper, right. 
192 THE DULE'S I' THIS BONNET O' MINE.

Aw 'm o' ov a tremble to th' heel,-

Dost think at my bonnet'll do?-

"Be off, lass, - thae looks very weel ;-

He wants noan o' th bonnet, thae foo!"

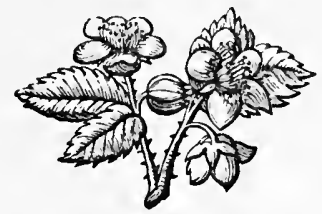




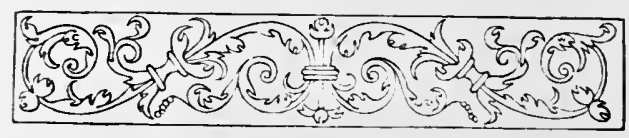

\section{TICKLE TIMES.}

I.

(3) ERE'S Robin looks fearfully glooms,

造通 An' Jamie keeps starin' at th' greawnd,

He's thinkin' o'th table at's empty,

An' th' little things yammerin' 1 reawnd;

It looks very dark just afore us,-

But, keep your hearts eawt o' your shoon, :-

Though clouds may be thickenin' o'er us,

There 's lots o' blue hearen aboon!

1 Yammerin', making an eager, hungry noise at meal-time.

2 Shoon, shoes.

C C 
II.

But, when a mon 's honestly willin', An' never a stroke to be liad, And clemmin' ${ }^{1}$ for want ov a shillin',--

No wonder 'at he should be sad;

It troubles his heart to keep seein'

His little brids 2 feedin' o'th air; An' it feels very hard to be deein', ${ }^{3}$ An' never a mortal to eare.

III.

But life 's sich a quarc ${ }^{4}$ bit o' travel,-

A marlock ${ }^{5}$ wi' sun an' wi' shade,An' then, on a bowster ${ }^{6} o^{\prime}$ gravel, They lay'n us i' bed wi' a spade;

1 Clemmin', starving for want of meat.

2 Little brids, little birds, little children.

3 Deein', dying.

4 Quare, queer.

s Marlock, frolic.

6 Bowster, bolster. 
It's no use a peawtin' an' fratehin' 1-

As th' whirligig 's twirlin' areawnd: Have at it again; and keep seratehin' As lung as yor yed 's upo' greawnd.

IV.

Iv one conld but grope i'th inside on't, There's trouble i' every heart; An' thoose that 'n th' biggest o'th pricle on't, Oft leeten ${ }^{2}$ o'th keenest o'th smart. Whatever may chanee to come to $\mathrm{ms}$, Let's patiently hondle er share,For there's mony a fine suit o' clooas, ${ }^{3}$ That covers a murderin' eare.

v.

There's danger i' every station,--

I'th palace as much as i'th eot;

1 Peawtin' an' fratchiv', pouting, and quarrelli.g.

2 Oft leeten, of light upon.

3 Cloous, clothes. 
There 's hanker ${ }^{1}$ i' every condition, An' canker ${ }^{2}$ i' every lot;

There 's folk that are weary o' livin'

That never fear't hunger nor cowd; An' there's mony a miserly nowmun, ${ }^{3}$ At's deed ov a surfeit o' gowd.

VI.

One feels, neaw at times are so nippin',

A mon's at a troublesome schoo', 'That slaves like a horse for a livin', An' flings it away like a foo ; But, as pleasur's sometimes a misfortin', $\mathrm{An}$ trouble sometimes a good thing,Though we livin' o'th floor, same as layrocks, ${ }^{4}$ We'n go up, like layrocks, to sing ?

I Hanker, to fret for, to long for something.

2 Canker, a sore place, dissatisfaction.

3 Nowmun, a silly felluw.

1 Layrocks, larks. 


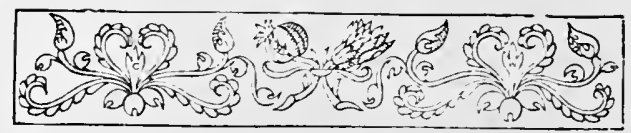

\section{JAMIE'S FROLIC.}

I.

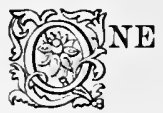

neet aw crope whoam when my

weighrin' were o'er,

To brush mo, an' wesh mo, au' fettle my yure ; ${ }^{1}$

Then, trailin' abeawt, wi' my heart i' my shoon,

Kept tryin' my hond at a bit ov a tune,

As Mally sit rockin',

An' darnin' a stockin',

An' tentin' 2 her bakin' i'th o'on.

1 Fettle my yure, put my hair to rights.

2 'Tentin', minding, taling care of. 
II.

Th' chylt were asleep, an' my clooas were reet, Th' baggin' 1 were ready, an' o' lookin' sweet;

But, aw're mazy, an' nattle, ${ }^{2}$ an' fasten't to tell What the dule it could be that 're ailin' mysel'; An' it made me so naught, That, o' someheaw, aw thought, "Aw could just like a snap at eawr Mall."

III.

Poor lass, hoo were kinder beeose aw were quare ;

"Come, Jamie, an' sattle thisel' ${ }^{3}$ in a cheer";

Thae's looked very yonderly ${ }^{4}$ mony a day;

It's grievin' to see heaw thae 'rt wearin' away,

1 Raggin', the afternoon meal.

2 Nattle, snappish, short-tempered.

3 Sattle thisel', settle thyseif.

- Yonderly, absent-minded, thinking far away. 
An' trailin' abeawt,

Like a hen at's i' th meawt; ${ }^{1}$

Do, pritho, poo up to thi tay!

IV.

" Thae wants some new flannels, - thae's getten a cowd,-

Thae 'rt noather so ugly, my lad, nor so owd,But, thae 'rt makin' thysel' into nought but a slave, Wi' weighvin', an 'thinkin', an' tryin' to save;-

Get summat to heyt, ${ }^{2}$

Or thae 'll go eawt o' seet,-

For thae 'rt wortehin' ${ }^{3}$ thisel' into th' grave.'

V.

Thinks I, " Th' lass 's reet, an aw houd with her wit;"

So, aw said,--for aw wanted to cheer her a bit,---

1 I'th meaut, in the moult, moulting.

2 Get summat to heyl, get somewhat to eat.

3 Wortchin', working. 
"Owd crayter, aw've noan made my mind up to dee, -

A frolick 'll just be the physic for me !

Aw'll see some fresh places,

An' look at fresh faces,-

An' go have a bit ov a spree!"

VI.

Then, bumpin' an' splashin' her kettle went deawn;

"I'th name o' good Katty, ${ }^{1} \mathrm{Jem}$, wheer arto beawn?

An' what sort o' faces dost want,-con to tell?

Aw deawt thae 'rt for makin' a foo o' thisel',-

The dule may tent th' oon;

Iv aw go witheawt shoon,

Aw 'll see where thae gwos to, mysel' !"

1 I'th name o' good Katty, an ancient saying, "In the name of good St. Catharine." 
vir.

Thinks I, " Th' fat's i'th fire,-aw mun make it no wur,-

For there 's plenty o' feightin' to do eawt o'th dur,-

So, aw 'll talk very prattily to her, as heaw,

Or else hoo 'll have houd o' my toppin ${ }^{1}$ in neaw ;"

An' bith leet in her e'cn,

It were fair to be seen

That hoo're ready to rive me i' teaw. ${ }^{2}$

VIII.

Iv truth mun be towd, aw began to be fain

To study a bit o' my ewortin' ${ }^{3}$ again ;

So aw said to her, "Mally, this world's rough enoo!

To fo' eawt ${ }^{4}$ wi' thoose one likes best, winnut do,-

1 Toppin', the hair on the front of the brow.

2 Rive me $i^{r}$ teaw, tear me into two.

3 Cwortin', courting.

- To fo' eaut, to fall out, to quarrel.

D $\mathrm{D}$ 


\author{
It's a very sore smart, \\ An' it sticks long i' th heart," - \\ An', egad, aw said nought but what's true!
}

IX.

Lord, heaw a mon talks when his heart's in his tung!

Aw roos't her, ${ }^{1}$ poor lass, an' showed hoo wur wrung, Till hoo took mo bith hond, with a tear in her e'e, An' said, “Jamie, there 's nob'dy as tender as thee! Forgi mo, lad, do;

For aw'm nobbut a foo, -

An' bide wi' mo, neaw, till aw dee !"

$\mathrm{x}$.

So, we'n bide one another, whatever may come;

For, there's no peace i'th world iv there's no peace a-whoam ;

1 Aw roos't her, I praised her. 
An' neaw, when a random word gi's her some pain, Or makes her a little bit cross in her grain,

Sunshine comes back,

As soon as aw crack

$O$ ' beginning my crortin' again. 


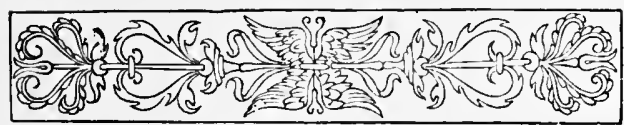

OWD PINDER.

I.

WD Pinder were a rackless ${ }^{1}$ foo,

An' spent his days i' spreein';

At th' end ov every drinkin-do,

He're sure to crack o' deein'; ${ }^{2}$

"Go, sell my rags, an' sell my shoon;

Aw's never live to trail 'em;

My ballis-pipes ${ }^{3}$ are eawt o' tune,

An' th' wynt ${ }^{4}$ begins to fail 'em !"

1 Rackless, reckless.

2 Crack o' deein', hint at dying.

3 Ballis-pipes, bellows-pipes, lungs.

$1 T h^{\circ}$ wynt, the wind, the breath. 
II.

“ Eawr Matty's very fresh an' yung ;-

'Twould any mon bewilder; - -

Hoo'll wed again afore its lung,

For th' lass is fond o' childer ;

My bit o' brass 'll fly,-_yo'n sce,-

When th' coffin-lid has screened me,-

It gwos again my pluck to dee,

An' lev ${ }^{1}$ her wick bcheend me."

III.

“ Come, Matty, come, an' cool my yed;

Aw'm finish'd, to my thinkin';"

Hoo happed him nicely up, an' said,

" Thae's brought it on wi' drinkin';" -

"Nay, nay," said he, " my fuddle's done;

We 're partin' tone fro tother ; ?

1 Lev, leave.

2 Tone fro tother, the one from the other. 
So, promise me that when aw'm gwon, Thea'll never wed another!"

IV.

“ Th' owd tale," said hoo, an' laft her stoo;

" Its rayly past believin';

Thee think o' th world thea 'rt goin' to, An' lev this world to th' livin'; What use to me can deeod folk be? Thae's kilt thisel' wi' spreein'; An' iv that's o' thae wants wi' me, Get forrud wi' thi deein' !" I

V.

He scrat his yed, he rubbed his e'e, An' then he donned his breeches;

' Get forrud wi' thi deein', get forward with thy dying. 
"Eawr Matty gets as fause," ' said he

"As one o' Pendle witches;"

Iv ever aw'm to muster wit,

It mun be now or never;

Aw think aw'll try to live a bit;

It would'nt do to ler her !"

1 Fause, cunning.

2 Pendle witches, Pendle Forest was notoriously associated with the old witch superstitions of Lancashire.

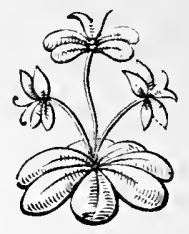




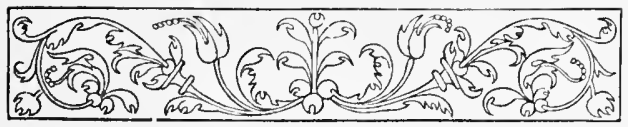

\section{TH' GOBLIN PARSON.}

I.

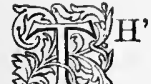

H' wynt wur still i'th shade o'th hill, An' stars began o' glowin'

I'th fadin' leet, one summer neet,

When th' dew wur softly foin';

Wi' weary shanks, by primrose banks,

Where rindlin' weet wur shinin',

Aw whistle't careless, wanderin' slow,

Toward my cot inelinin'.

1 Rindlin' weet, a little wandering, musical rill. 
II.

Through th' woodlan' green aw tooted ${ }^{1}$ keen,

For th' little window winkin';-

Th' stars may shine, they 're noan as fine

As Matty's candle blinkin';

O'er th' rosy hedge aw went to th' ridge

O'th lonesome-shaded plantin',

To get another blink o'th leet

That set my heart a-pantin'.

III.

Then deawn bi'th well i'th fairy-dell, Wi' trees aboon it knittin', Where, near an' fur, ther nowt astir But bats i'th eawl-leet ${ }^{3}$ flittin'; An' feeorfu' seawnds that rustle't reawnd I' mony a goblin-flitter,

1 Tooted, peeped.

2 Plantin', plantation.

3 Eaul-leet, twilight, when owls begin to cry. E E 
As swarrnin' dark to flaysome wark'

They flew wi' fiendish titter.

IV.

Theer, reet anent, aw geet a glent ${ }^{2}$

At brought a shiver o'er me,

For, fair i'th track ther summat black

Coom creepin' on afore me ;

It war not clear-but it wur theer-

Wi' th' gloomy shadow blendin',

Neaw black an' slim, neaw grey an' grim,

Wi' noather side nor endin'.

v.

Cowd drops wur tremblin' o' my broo,

As there aw stoode belated ; ${ }^{3}$

Aw durstn't turn,-_aw durstn't goo,-

But shut my e'en, an' waited;

1 Flaysome wark, fearful work.

2 Reet anent au geet a glent, right a-head I got a glimpse.

Belated, benighted. 
An' just as aw begun to pray,

There coom fro' th' creepin' spectre

A weel known voice, that said, "Well, James !"-

'Twur nowt but th' village rector.

rI.

"Well, James," said he, "I 'm fain to sce

Yor pew so weel attended,

But then, yo shouldn't fo' asleep

Áfore my sarmon's ended;

To dreawsy ears it's useless quite

To scatter holy teychin' ;'

Why don't yo bring a bit o' snuff,

An' tak it while I'm preychin'."

VII.

" Well, well," said aw, "thcre's mony a way

O' keepin' e'en fro closin',

1 Teychin', teaching.

2 Preychin', preaching. 
A needle would keep th' body wake, An' th' soul may still be dozin';

But this receipt would set it reet,

Iv th' mixture wur a warm un,-

Yo' get some stingin' gospel-snuff,

An' put it into th' sarmon."

VIII.

He stare't like mad, but th' good owd lad

Then grip't my hond, warm-hearted,

An' said, "Yo're reet, yo're reet-good neet!"

An' that wur heaw wo parted.

It touched my heart, an' made it smart,

He spoke so mild and pratty;-

Aw blest him as he walked away,

An' then went whoam to Matt.y.

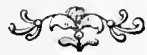




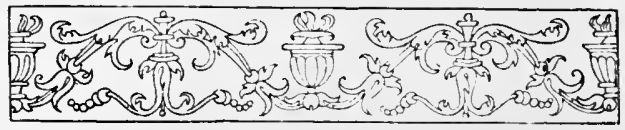

\section{COME, JAMIE, LET'S UNDO THI SHOON.}

I.

OME, Jamie, let's undo thi shoon;

g

Wi' toilin' i'th sheaw'r up an' deawn;

Aw'm fleyed ${ }^{2}$ at thi stockin's are weet;

An', here, wi' my yung uns i'th neest,

Aw bin heark'nin' to th' patter o' th rain,

An' longing for th' wanderin' brid

To comfort my spirits agaim.

1 Don, to do on, to put on. $\quad 2$ Flesed, afrial. 
II.

To-day, when it pelted at th' lieiglit,

"Aw 'll ston it no longer," said I ;

For, rayly, ${ }^{1}$ it didn't look reet

To keawer ${ }^{2}$ under cover so dry ;

So, though it were rainin' like mad,

Aw thought-for my heart gav a swell,-

"Come deawn asto will, but yon lad

Shall not have it o' to his-sel'!"

$1 I I$.

So, whippin' my bucket i'th rain,

Aw ga' th' bits o' windows a swill ;

An', though aw geet drenched to my skin,

Aw 're better content wi' mysel' ;

But, theaw stons theer smilin' o'th floor,

Like a sun-fleawer drippin' wi' weet;

- Rayly, really.

2 Keawer, to sit, to rest in a couching posture. 
Eh, Jamie, theaw knowsn't, aw' 'm sure,

Heaw fain aw'm to see tho to-neet!

IV.

Eh, lass, what's a sheawer to me?

Aw've plenty o' sun in my breast,

Mi wark keeps me hearty an' free,

An' gi's me a relish for rest;

Aw'm noan made o' sugar nor saut,

That melts wi' a steepin' o' rain;

An', as for my jacket,-it 's nouglit,-

Aw 'il dry it by th' leet o' thi e'en !'

จ.

Come, sit tho deawn elose by my side,-

Aw 'm full as a cricket wi' glee;

Aw'm trouble't wi' nothin' but pride,

An' o' on it owin' to thee;

- Th' leet o' the e'en, the light of thine eyes. 
216 COME, JAMIE, LET'S UNDO TIII SHOON.

Theaw trim little pattern for wives;-

Come, give a poor body a kiss!

Aw wish every storm ov our lives

May end up as nicely as this!

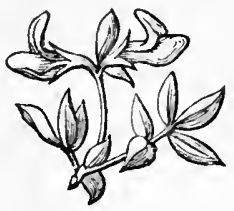




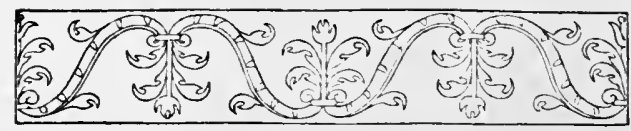

WHILE TAKIN' A IVIFT O' MY PIPE.

I.

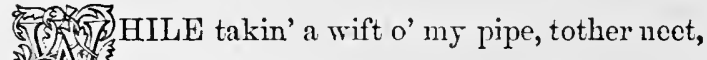

A thowt trickled into my pate,

That sulkin' becose everything isn't swect,

Is nobbut a foolish consate ${ }^{1}$

Iv mon had bin made for a bit of a spree,

An' th' world were a marlockin' schoo,?

Wi' nought nobbut heytin', an' drinkin', an' glee,

An' haliday gam ${ }^{3}$ to go through,

He'd sicken afore

His frolic were o'er,

An' feel he'd bin born for $a$ foo.

1 Consate, conceit.

2 Marlockin'schoo', a frolicking school.

s Haliday gam, holiday game, boliday fun. F F 
II.

Poor crayter, he 's o' discontentment an' deawt, Whatever his fortin may be;

He 's just like a chylt ' at goes cryin' abeawt,

"Eawr Johnny's moor traycle nor me ;"

One minute he 's trouble't, next minute he's fain, An' then, they're so blended i' one,

It's hard to tell whether he's laughin' through pain,

Or whether he 's peawtin' for fun;-

He stumbles, an' grumbles,

He struggles, an' juggles,-

He capers a bit, - an' he 's gone.

III.

It's wise to be humble i' prosperous ways,

For trouble may chance to be nee $;^{2}$

It's wise for to struggle wi' sorrowful days,

Till sorrow breeds sensible glee; 
He's rich that, contented wi' little, lives weel, An' nurses that little to moor;

He's weel off at's rich, iv he nobbut can feel

He's brother to thoose that are poor;

An' to him 'at does fair,

Though his livin' be bare,

Some comfort shall ever be sure.

IV.

We'n nobbut a lifetime a-piece here below,

An' th' lungest is vel'y soon spent;

There 's summat aboon measur's cuts ${ }^{1}$ for us o',

An' th' most on 'em nobbut a fent ; ${ }^{2}$

Lung or short, rough or fine, little matter for that,

We'n make th' best o'th stuff till it's done,

1 Cuts, a name for a weaver's piece, or wel, of cloth.

: Fent, a part or fragment of the web of cloth. 
220 WHILE TAKIN' A WIFT O' MY PIPE.

An' when it leets eawt to get rivven ' a bit,

Let's darn it as weel as we con ;

When th' order comes to us

To doff these owd elooas, ${ }^{2}$

There'll surely be new uns to don.

1 Krvven, torn.

${ }^{2}$ Clooas, clothes.

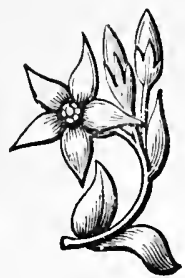




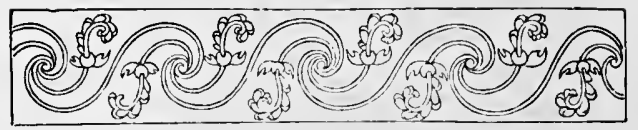

GOD BLESS THI SILVER YURE!

I.

2in

Le reawsty ${ }^{\prime}$ iron to feel,

There's very fow i'th lond

Aw like to gripe ${ }^{2}$ as weel.

Tha'll never dee i'th dumps

Becose o' bein' poor,

Thae good owd king o' trumps,-

God bless thi silver yure!

II.

Poo up to th' side o'th lob, ${ }^{3}$

An' rest thi weary shanks,

' heawsty, rusty. 2 Gripe, grip.

$2 H o b$, a ledge close to the fire-grate. 
An' dunnot. fret thy nob

Wi' fortin an' her pranks ;

These folk at's preawd an' rich

May tremble at her freawn;-

They'n further far nor sich

As thee to tumble deawn.

III.

Thaew never longs for wine,

Nor dainties rich an' rare,

For sich a life as thine

Can sweeten simple fare;

Contented wi' thi meal,

Thae's wit enough to know

That daisies liven weel

Where tulips connot grow.

IV.

An' though thi clooas ${ }^{2}$ are rough,

An' gettin' very owd,

- Liven, do live.

2 ('lovis, clothes. 
They'n onswer weel enough

To keep thi limbs fro' cowd;

A foo would pine away

I' sich a suit as thine,

But, thaer't the stuff to may

A fustian jacket fine.

V.

A tattered clout may lap

A very noble prize;

A king may be, by hap,

A beggar i' disguise.

When tone has laft his feast,

An' tother done his crust,'

Then, which is which, at last, -

These little piles o' dust?

1 "When tone has laft his feast, An' tother done his crust."

"When the one has left his feast, And the other done his crust." 
VI.

An' though thy share o' life,

May seem a losin' game,

Thae's striven fair i'th strife,

An' kept a dacent aim ;

No meawse-nooks ' i' thi mind,

Nor malice i' thi breast,

Thae 's still bin true an' kind,

An' trusted fate wi' th' rest.

VII.

Through trouble, toil, an' wrung,

Thae's whistle't at thi wark,

Thae's wrostle't life so lung,

Thi limbs are gettin stark;

But, sich a heart as thine's

A never failin' friend;

It cheers a mon's decline,

An' keeps it sweet to th' end.

1. Meawse-nooks, secret places. 
VIII.

Thy banner 'll soon be furled, An' then they 'n ha' to tell,

" He travelled th' dirty world, An' never soil't his-sel' !"

An' when aw come to dee,

An' death has taen his tow,

Aw hope to leet ${ }^{2}$ o' thee,-

God bless thy snowy pow ! ${ }^{3}$

1 Tow, toll.

2 Leet, to alight upon, to meet with.

3 Pow, poll.

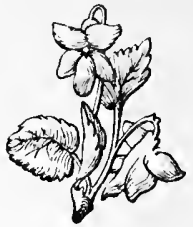

F F 


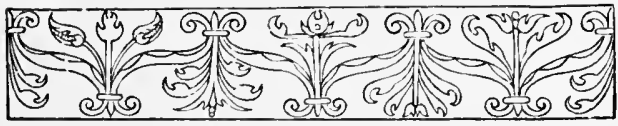

\section{MARGIT'S COMIN'.}

1.

$\mathrm{H}$ ! Sam, whatever doesto meeon?

Aw sce thae'rt thecr i'th nook again ;-

Where aw 've a gill thae's nine or ten ;

Hast dropt into a fortin?

Aw wonder heaw a mon ean sit

An' waste his bit o' wage an' wit:

Iv aw 're thi wife, aw'd make tho flit,-

Wi' little time to start in.

II.

But, houd; ,yo'r Margit's up i'th teawn ;

Aw yerd her ax for thee at th' Crown; 
An' just meet neaw, aw scamper't deawu ;It's true as aught i'th Bible!

Thae knows yo'r Margit weel, ov owd ;

Her tung,-it makes mo fair go cowd, Sin' th' day hoo broke my nose i'th fowd Wi' th' edge o'th porritch thible.'

III.

It's ten to one hoo 'll ${ }^{3} \mathrm{co}^{\text {' in here, }}$ An' poo ${ }^{4}$ tho eawt o'th corner checr; So, sit fur ${ }^{5}$ back, where th' l'unnin's clear ;-Aw 'll keep my een o'th window ; Thac'm, ${ }^{6}$ mind thi hits, an' when aw sheawt, Be limber-legged, ${ }^{7}$ an' lammas ${ }^{8}$ eawt ; An', though hoo 'll not believe, aw deawt, Aw'll swear aw never sin tho.

1 Ov oud, of old.

2 Porritch thible, a piece of wood to stir boiling porridge with.

3 Hoo'll, she'll, she will. $\quad$ Poo, pull.

s Fur, further.

f İate m.thor mu it.

7 Limber-legged, nimble-legged.

a lammas, to run away. 
IV.

Aw 'll bite my tung, ${ }^{1}$ aw will, bith mon;

Aw'll plug my ears up, till hoo's gone;

A grooin' tree ${ }^{2}$ could hardly ston

A savage woman flytin';

Iv folk were nobbut o' i'th mind

To make their bits o' booses ${ }^{3}$ kind,

There 'd be less wanderin' eawt to find

A corner to be quiet in.

v.

It's nearly three o'clock bith chime:

This ale o' Jem's is very prime;

Aw 'll keawer mo deawn till baggin-time, ${ }^{4}$

An' have a reech ${ }^{5}$ o' bacen;

1 Tung, tongue.

2 A grooin' tree, a growing tree.

3 Booses, resting-places, generally applied to the stalls of a cattle-shed.

1 Aw'll keauer mo deaun till baggin' time, I will sit me down till the afternoon meal-time.

5 Reech, a smoke. 
Aw guess thae 's yerd o' Clinker lad'

An' Liltin' Jenny gettin wed ; ${ }^{2}$

An' Collop gooin' wrang i'th yed, ${ }^{3}-$

But, that's nought mich to crack o'."

VI.

There's news that chaps 'at wore a creawn,

Are getting powler't ${ }^{5}$ up an' deawn

They 're puncin' ${ }^{6}$ 'em fro teawn to teawn,

Like foot-bo's in a pastur ; ${ }^{7}$

Yon Garibaldi 's gan 'em silk ;

Th' owd lad; he's fairly made 'em swilk ;9

'Thae's yerd o' Clinker lad, thou hast heard of Clinker's lad.

2 Gettin wed, getting married.

3 II rang $i$ 'th yed, wrong in the bead, crazy.

4 That's not mich to crack o', that 's not much to talk of, or to wonder at.

5 Pouler't, jolted, knocked to and fro.

6 Puncin', kicking.

7 Like foot-bo's in a pastur', like footballs in a fielul.

${ }^{8}$ Gan'em silk, given them silk, thrashed them finely, thoroughly.

9 Swilk, to make a noise inside, like a half-filled barrel, when shakelu. 
An' neaw, they sen he 's sellin' milk '

To raise new clooas for Ayster. ${ }^{2}$

VII.

There 's some are ereepin' eawt o'th slutch, ${ }^{3}$

An' some are gettin' deawn i'th doitch ; ${ }^{4}$

Bith mon, ${ }^{5}$ aw never yerd of sich

A world for change o' fortin' !

They 're gooin' groanin' eawt o'th seet,

They 're comin' cryin' into th' leet;

But, howd! aw yerd, o' Monday neet,

A tale abeawt a cwortin'. ${ }^{6}$

1 He 's sellin' milk, an allusion to Garibaldi's farming in the isle of Caprera.

2 To raise new clooas for Ayster, to raise new clothes for Easter. Country people in Lancashire generally make a superstitious struggle to wear some kind of new clotling on Easter Sunday.

is Slutch, mire.

4 Doitch, ditch.

5 Bith mon, by the man, an ancient allusion to the Saviour of mankind.

6 Currtin', courting. 
VIII.

Poo up!' aw 'll tell it iv aw con ; -

Thae knows that little bow-legged mon-

But, heigh,—owd lad ! yo'r Margit's yon,- -

Hoo 's comin' like a racer :-

Some foo ${ }^{2}$ has put her upo' th' track;

Cut, Sam; hoo'll have us in a erack !

Aw said hoo'd come-let's run eawt th' back ;

Bith mass, ${ }^{3}$ aw dar not face her!

1 Poo up, pull up. $\quad 2$ Foo, fool.

3 Bith mass, by the mass. 


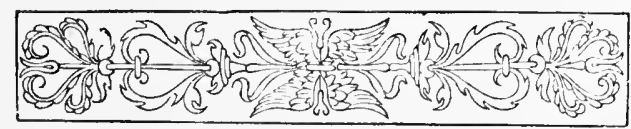

\section{TH' SWEETHEART GATE.}

I.

15ำ teawn-end,-

But nobbut one ${ }^{2}$ for me;

It winds by a rindlin' wayter side,

An' o'er a posied lea;

It wanders into a shady dell;

An' when I've done for th' day,

I never can sattle ${ }^{3}$ this heart o' mine,

Beawt ${ }^{4}$ walkin' deawn that way.

1 Gate, road, way.

2 Nobbut one, nought but one, only one.

3 Sattle, settle, put to rest.

4 Beawt, without. 
II.

It's noather, ${ }^{5}$ garden, nor posied lea,

Nor wayter rindlin' 6 elear ;

But deawn i' th vale there's a rosy nook,

An' my true love lives theer :

It's olez ${ }^{7}$ summer where th' heart's content,

Tho' wintry winds may blow ;

An' there's never a gate ${ }^{8}$ so kind to th' fnut,9

As th' gate one likes to go.

III.

When I set off o' sweetheartin', I've

A theawsan' things to say;

But th' very first glent ${ }^{10}$ o' yon chimbley-top,

It drives 'em o' away ;

5 Noather, neither.

6 Wayter rindlin', water wandering musically.

7 Olez, always.

8 Gate, road, path, way.

9 To th' fuut, to the foot.

10 Glent, a glimpse. 
An' when I meet wi' my bonny lass,

It sets my heart a-jee;-

There's summut i'th leet ${ }^{11} o^{\prime}$ yon two blue e'en

That plays the dule wi' me!

IV.

When th' layrock's finished his wark aboon, ${ }^{12}$ An' laid his music by,

He flutters deawn to his mate, an stops

Till dayleet stirs i'th sky. ${ }^{13}$

Though Matty sends me away at dark,

I know that hoo's reet ${ }^{14}$ full well ;-

An' it's heaw I love a true-hearted lass,

No mortal tung ${ }^{15}$ can tell.

$11 T h$ ' leet, the light.

12 When th' layrock's finished his wark aboon, when the lark has finished his work above.

13 Till dayleet stirs i'th sky, till the dawning of the day.

14 Hoo's reet, she's right.

15 Tung, tongue. 
v.

I wish that Michaelmas Day were past,

When wakin' time ${ }^{16}$ comes on ;

An' I wish that Candlemas Day were here,

An' Matty an' me were one:

I wish this wanderin' wark were o'er-

This maunderin' 17 to an' fro ;

That I could go whoam to my own true love,

An' stop at neet an' 0 . ${ }^{18}$

16 Wakin' time, the time when workmen begin to work by candle-light.

17 Maunderin', wandering aimlessly, dreamily.

18 That aw could go uhoam to my own true lore, An' stop at neet an' o'.

That I could go home to my own true love, And stop at night and all.

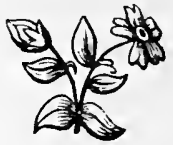




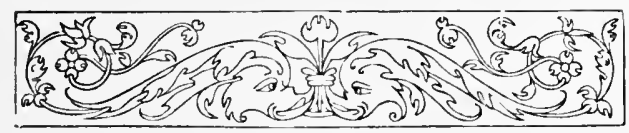

OWD ENOCH.

I.

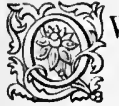

WD ENOCH o' Dan's laid his pipe deawn o' th' hob,'

And his thin fingers played i' th white thatch of his nob $;^{2}$

"I 'm gettin' done up," to their Betty he said;

"Dost think thae could doff $\mathrm{mo}^{3}{ }^{3}$ an' dad me ${ }^{4}$ to bed?"

Derry down, \&c.

$1 H o b$, a ledge, close to the fire-grate.

2 White thatch ov his nob, the white hair of his head.

3 Doff mo, do off for me, or take off my clothes for me.

- Dad me, help me by the hand, as a "dad," or father does a little child in its first efforts to walk. 
II.

Then hoo geet him to bed, an' hoo happed him up weel, ${ }^{5}$

An' hoo said to him, "Enoch, lad; heaw doesto feel ?" 6

“These limbs o' mine, Betty,-they 're cranky an' sore ${ }^{7}$

It's time to shut up when one's getten fourscore."

Derry down.

III.

As hoo potter't abeawt ${ }^{8}$ his poor winterly pate, Th' owd erayter looked dreawsily up at his mate,--

5 Happed him up weel, lapped, or folded him up well.

6 Heaw doesto feel? How dost thou feel?

7 Cranky an' sore, rusty and shaky, and painful.

8 Potter't abeawt, fumbled, or fingered, caressingly. 
'There 's nought on me laft, lass,-do o' at tho con, -9

But th' cratchinly ${ }^{10}$ frame o' what once wur a mon."

Derry down.

IV.

Then he turn 't his-sel' o'er, like a chylt tir 't wi' play, ${ }^{11}$

An' Betty crept reawnd, while he 're dozin' away;

As his e'e-lids sank deawn, th' owd lad mutter't "Well done!

I think there's a bit o' seawnd sleep comin' on."

Derry down.

9 There's nought on me laft, lass,-do o' at tho con,-there's nothing of me left, lass,-do all that thou can'st.

10 Cratchingly, ill-conditioned, shakely-held together.

11 He turn't his-sel' o'er, like a chylt tir't wi' play, he turned himself over, like a child tired with play. 
V.

Then hoo thought hoo'd sit by till lie'd had his nap o'er,-

If hoo'd sit theer till then, hoo'd ha' risen no more ;

For he cool 't eawt o'th world, an' his e'en lost their leet, ${ }^{12}$

Like a cinder i'tl fire-grate, i 'th decod time o'th neet. $^{13}$

Derry down.

VI.

As Betty sit rockin' bith' side of his bed,

Hoo looked neaw an' then at owd Enoch's whito yed;

12 He cool't eawt o'th world, an' his e'en list their leet, he cooled out of this world,- be died,-and his eyes lost their light.

${ }^{13}$ I'th deeod time o'th neet, in the dead, or silent, time of the night. 
An' hoo thought to her-sel' that hoo'd not lung to stay

Iv ever th' owd prop of her life should give way.

Derry down.

FII.

Then, wond'rin' to see him so scawnd an' so still,

Hoo touched Enoch's hond,-an' hoo fund it wur chill ;

Says Betty, "He's cowd; I'll put summat moor on!" 14

But o' wur no use, ${ }^{15}$ for Owd Enoch wur gone!

Derry down.

14 He's cowd; aw'll put summat morr on, he is cold; I will put something more, or more clothing, upon him.

$15 O^{\prime}$ wur no use, all was no use. 
VII.

An' when they put Enoch to bed deawn i' th greawnd, ${ }^{16}$

A rook o' poor neighbours stoode bare-yedded reawnd ; ${ }^{17}$

They dropt sprigs o' rosemary ; an' this wur their text:-

" Th' owd crayter's laid by, ${ }^{18}$ - we may haply be th' next!"

Derry down.

IX.

So, Betty wur left to toar on bi hersel' ; ${ }^{19}$

An' heaw hoo poo'd through it no mortal can tell;

16 Deaun i' th' greaund, down in the ground.

17 Stoode bare-yedded reaund, stood bare-headed around.

18 Th' owd crayter's laid by, the old creature is laid aside. The words "owd crayter," are commonly used as a phrase of affection.

19 To toar on bi her-sel', to drag on wearily hy herself, or, alone 
But th' doctor dropt in to look at her one day, When hoo're rockin' bith' side of an odd cup o' tay. ${ }^{20}$

I)erry down.

$x$.

"Well, Betty," said th' doctor, "heaw dun yo get on?

I'm soory to yer 'at yo'n lost yo'r owd mon :

What complaint had he, Betty?" Says hoo, "I caun't tell ;

We ne'er had no doctor; he dee'd of his-sel'." 21

Derry down.

$\mathrm{XI}$.

"Ay, Betty," said th' doctor; " there's one thing quite sure;

Owd age is a thing that no physic can cure:

20 Bith side ov an odd cup o' tay, by the side of a lonely cup of tea.

21 We ne'er had no doctor; he dee'd ov his-sel', we never had 
Fate will have.her way, lass,-_do o' that we con, -

When th' time's up, we's ha' to sign o'er, an' be gone." 22

\author{
Derry down.
}

XII.

"Both winter an' summer th' owd mower's at wark, ${ }^{23}$

Sidin' folk eawt o' seet, ${ }^{21}$ both bi daylect an' dark? He's slavin' away while we're snorin' i' bed; An' he'd slash at a king, if it coom in his yed." 25 Derry down.

any doctor to bim; he died of himself, or, without the aid of medicine.

22 W'e's ha' to sign o'er, an' be gone, we shall have to consign, or hand over our worldly affairs, and be gone.

${ }_{23} T h$ 'owd mower's at wa k, the old mower, - deatl, -is at work.

24 Sidin' foolk eawt o' seet, putting people aside, out of sight.

25 If it coom in his yed, if it came into his bead, or, if he chanced to think of it. 
XIII.

“' These sodiurs, an' parsons, an' maisters o' lond, ${ }^{26}$

He lays 'em i' th greawnd, wi' their meawths full o' sond,

Rags or riches, an' owd greasy cap, or a creawn-

He sarves o' alike,-for he switches 'em deawn." Derry down.

XIV.

"The mon that's larn't up, an' the mon that's a foo-27

It mays little odds, for they both han to goo ; 98

${ }^{26}$ Maisters o' lond, masters of land, landowners.

27 The mon that's larnt-up, an' the mon that's a foo, the man that is learned-up to the height of possibility, or, that knows everything,-and the man that is a fool.

as It mays little odds, for they both han to gon, it makes little difference, for they botlı have to go. 
Whon they come'n within th' swing of his scythe they mun fo'-

If yo'n root amung th' swathe, jo'n find doctors

$$
\text { an’ } 0 . " \text { \&9 }
$$

\section{Derry down.}

24 Io yo'n root amung th' sucuthe, yo'n find dictors $a n^{\prime} o^{\prime}$, if you will examine the swathe left by the scythe of death, you will find that even those whnse business it is to sare the lives of others, die, like the rest.

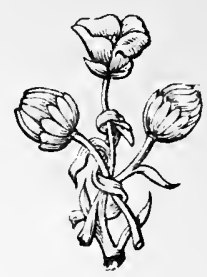




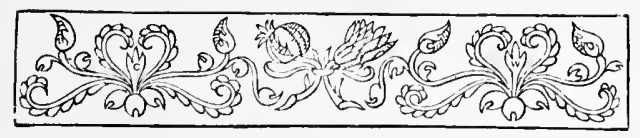

\section{EAWR FOLK.}

I.

R Johnny gi's his mind to books;

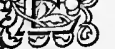

Er Abram studies plants,-

He caps the dule' for moss an' ferns, An grooin' polyants $;^{2}$

For aught abeawt mechanickin',

Er Ned's the very lad;

My uncle Jamie roots i'th stars, ${ }^{3}$

Enough to drive him mad.

1 Caps the dule, beats the devil, or excels the devil.

2 Grooin' polyants, cultivating the polyanthus.

3 Roots i'th sturs, studies astronomy. 
II.

Er Alick keeps a badger's shop, ${ }^{4}$

An teyches Sunday schoo' ;

Er Joseph's welly blynt, ${ }^{6}$ poor lad :

Er Timothy's-a foo;

$\mathrm{He}$ 's tried three different maks ${ }^{7}$ o' trades,

An' olez missed his tip ; ${ }^{8}$

But, then, he's th' prattist 9 whistler

That ever cock'd a lip!

III.

Er Matty helps my mother, an'

Hoo sews, an' tents er Joe ; ${ }^{10}$

At doin' sums, an' sich as that, My feyther licks 'em 'o;

4 A badger's shop, a grocer's shop.

s Teyches Sunday schoo', teaches in a Sunday school.

6 Welly blynt, well-nigh blind.

7 Maks, makes, shapes, kinds.

8 Missed his tip, missed his aim, broken down.

- Prattist, prettiest, most pleasing.

10 Tents er Joe, takes care of our Joe. 
Er Charley,-well,- - there connot be Another pate like his,It's o' crom-full o' ancientry, ${ }^{11}$ An' Roman haw-pennies ! ${ }^{2}$

IV.

Er Tummy's taen to preitchin',- ${ }^{13}$

He's a topper at it, too;

But then,-what's th' use-cr Bill comes in, An' swears it winnot do ; When t'one's bin strivin' o' he con ${ }^{14}$ To awter wicked men, Then t'other mays some marlocks, ${ }^{15}$ an' Convarts 'em o'er again.

"Crom-full o' ancientry, cram full of antiquarian lore.

12 Koman haw-pennies, Roman half-pennies, Roman coins.

13 'Taen to preitchin', taken to preaching, become a preacher.

14 When t'one's bin strivin' o' he con, when the one has been striving all he can.

15 T'other mays some marlocks, the other makes some frolics. 
v.

Er Abel's th' 5ung'st; an'-next to Joe,-.

My mother like's him t' best:

Hoo gi's him brass, aboon his share, ${ }^{16}$

To keep him nicely drest; -

He 's gettin' in wi' th' quality, - ${ }^{19}$

An' when his elarkin's done,

He 's olez oather ${ }^{18}$ ericketin',

Or shootin' wi' a gun.

VI.

My Uncle Sam's a fiddler; an'

I fain could ger $^{19}$ him play

Fro' set o' sun till winter neet

Had melted into das ;

${ }^{16}$ Hoo gi's him brass aboon his share, sle gives him more woney than his share.

$17 \mathrm{He}$ 's gettin' in wi' th' quality, he is becoming acquainted with people in ligh life.

18 Olez oather, always either.

19 Aw fain could yer him play, I gladly could listen to his playing. 
For eh,--sich glee-sich tenderness-

Through every changin' part,

It's th' heart that stirs his fiddle,-

An' his fiddle stirs his heart!

VII.

An', when he touches th' tremblin'-streng, ${ }^{20}$

It knows his thowt ${ }^{21}$ so weel,

It seawnds as if an angel tried

To tell what angels feel;

An', sometimes, th' wayter in his e'en ${ }^{\circ:}$

That fun has made to flow,

Can hardly roll away, afore

It's blent wi' drops o' woc.

VIII.

Then, here's to Jone, an'Ab, an' Ned, An' Matty,-an' er Joe,-

20 Th' tremblin' streng, the vibrating fiddle-string.

21 Thowt, thought.

22 Th' wayter in his e'en, the water in lis eyes. 
An', my feyther, an' my mother ; an'

Er tother lads an' o';

An' thee, too, owd musicianer,-

Aw wish lung life to thee,-

A mon that plays a fiddle weel

Should never awse ${ }^{23}$ to dee!

23 Should never ause, should never attemit.

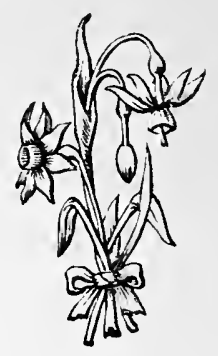




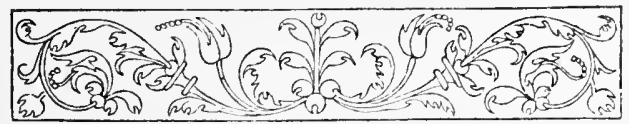

FORGIVE ONE ANOTHER.

I.

I OME here, my bold cronies, I'll not keep

yo' lung, -

Come hither, an' hearken do me ;

I'll chant yo a neighbourly snateh of a sung,-

An' th' end o' my ditty shall be,-

Let's forgive one another!

II.

We're a wanderin' band, in a ticklesome land,

Where never a mortal can stay, 
When yo see'n folk 'at's weary, lads, lend 'em a' hand,An', oh, -as we re joggin' away, -

Let's forgive one another!

III.

This will-o'-the-wisp in a poor borly's breast,

It flutters the life of a mon;

It plays him wild marlocks that rub him o' rest,---

A mortal may do what he con,--

Let's forgive one another !

IV.

Like harp-strings, we're made of a different tone, An' th' minstrel, he sits up aboun;

To him, every note o' the gamut's weel known,Let's hope that he'll keep ns i' tune, To forgive one another ! 
v.

At neet, when a mother's her childer undrest,

They paddle'n up close to her knee,

To whisper a prayer afore gooin' to rest;

An', th' sweetest o' th' strain, unto me,

Is,-forgive one another !

VI.

Some liken to wrangle o'er nonght but a name, An' who wur their mams an' their dads;

But, gentle or simple, it ends up the same,-

"We're o' Johnny Butteroth lads!" 1

Let's forgive one another !

VII.

When thinkin' o' life, an' its troublesome way,

We'n very leet need ${ }^{\mathfrak{a}}$ to be proud;

1 "We're o' Johnny Butter'oth lads"- a common saying in Jancashire, meaning that we are all God Almighty's children.

2 Very leet need, very light need, very little need. 
Strike honds while yo're wick ; for yo'n not long to stay;

It's late, when yo're lapped in a shreawd

To forgive one another

VIII.

An' neaw, - as we never may o' meet again,-

For, th' futur' no mortal can see,-

I'll stick to my text, lads ; an', as it began,

So th' end o' my ditty shall be,-

Let's forgive one anotlier !

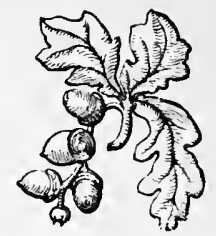




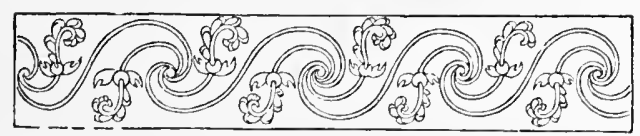

BUCKLE TO.

I.

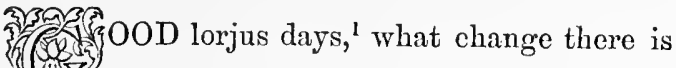
Upon this mortal ground;

As time goes flyin' o'er one's yed, ${ }^{2}$

Heaw quarely things come reawnd;

What ups an' deawns, an' ins an eawts ;-

What blendin' ill an' well

There is i' one poor crayter's ${ }^{3}$ life, -

It is not for to tell !

1 Good lorjus days, Good lord of our days.

2 Yed, head. $\quad 3$ Crayter, creature. 
11.

When mornin' blinks, mon lies an' thinks

Abeawt the comin' day ;

He lays his bits o' schames so sure,

They connot roll astray;

He eracks his thumbs, an' thinks o'll leet,"

Just heaw it's planned to go ;

But, when he looks things up at neet,"

He seldom finds it so.

III.

An' when a storm comes, dark an' leawd,-

Wi' mony a weary sigh,

He toots abeawt, ${ }^{6}$ i'th slifter't cleawd,

To find a bit o' sky;

4 Thinks o "ll leet, thinks everything will light or befiil.

- Neet, night.

6 Toots abeuwt, peeps about, searches.

7 Slifter'd cleaud, slifter, a slit, or loophole; slifteril cleawd, a slit, or broken, or sliglitly-scattered cloud. 
Ho mopes an' moans, he grunts an' groans, An' thinks his comfort's o'er ; But, th' minute th' welkin 's s breet again, He's peearter ${ }^{9}$ than before.

IV.

Good luck to th' mortal that can ston

Good luck, beawt bein' preawd;

That keeps his yed fro grooin' whot,- ${ }^{10}$

His heart fro grooin' cowd ;"

That walks his chalks, an' heeds no talks, But does the best he con ; ${ }^{12}$ An' when things are not to his mind, Can bide it like a mon. ${ }^{13}$
8 Th' welkin, the sky.
9 Peearter, perter, prouder.
10 Grooin' whot, growing hot.
1t Grooin' cowd, growing cold.
12 Con, can.
13 Hon, man. 
V.

Then, let's be lowly when its fine, An' cheerful when its dark;

Mon ne'er wur made to mope an' whine, But buckle to his wark ; 14

It sweetens th' air, it leetens eare,-

I never knew it fail :

Go at it, then,-_an' let 's toe fair $;{ }^{15}$

Owd Time'll tell a tale.

14 I'ark, work.

15 Toe fair, toe the mark fairly. Do justice; act " upon the square."

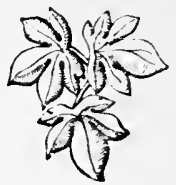




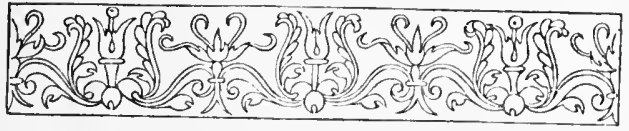

\section{NEET-FO'.}

I.

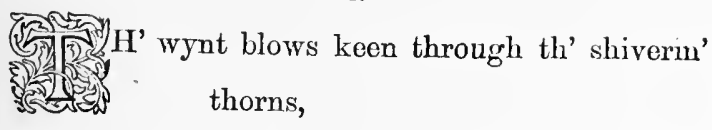

An' th' leet' looks wild i'th sky;

Come, Tet, stir up that fire; an' draw

That keyther" gently by ;

I 've done my weshin', gronny; an'

I 've tidied every thing,

An', neaw I 'll sit me deawn to sew,

An' hearken th' kettle sing.
Ieet, light.
2 Keyther, cradle. 
II.

Bring in some coals ; an' shut that dur,-

Its quite a wintry day;

Reiteh deawn that ham: for Robin likes

A relish to his tay. ${ }^{3}$

Sweep th' grate; an' set yon table sawt;

Put th' tay-pot upo' th' oon ;"

Its gettin' on for baggin'-time,

An' he 'll be eomin' soon.

III.

Th' fire bruns ${ }^{6}$ elear; an' th' heawse begins

A-lookin' brisk an' breet,

As th' time draws near when he gets back

Fro' teawn at th' edge o' neet;

3 Tay, tea.

1 U'po' th' oon, upon the oven.

5 Baggin'-time, tea-time, or time of the aftrnoon me'al.

6 Bruns, burns. 
It makes one hutch ${ }^{\tau}$ wi' glee to yer

A favourite funt come whoam;

An' its very fine to hearken, when

One thinks it's sure to come.

IV.

Th' cat pricks up her ears at th' sneek, ${ }^{8}$

Wi' mony a leetsome toot $;^{9}$

An' th' owd arm-cheer i'th corner seems

As if it yerd his funt;

Th' window blinks; an' th' clock begins

A-tickin' leawd an' fain ;

An' th' tin things winkin' upo' th' wole,_-"

They groon as breet again. ${ }^{11}$

v.

'Th' kettle's hummin' o'er wi' fun-

Just look at th' end o'th speawt;

7 Hutch, to twitch, to shrug, to wriggle the body uneasily.

8 Sneck, an old-fashioned wooden latch.

- Toot, to peep. 10 Wole, the wall.

$"$ They groon as breet again, they become twice as bright. 
Its like a little sooty lad

That's set his lips to sheawt:

Th' wayter-drops 'at fo'n fro' th' tap,

Are gettin' wick wi' glee;

An' yo're fain, gronny, too,-I know,-

But noan as fain as me!

VI.

Keep th' rockers gooin' soft and slow,

An' shade that leet away;

I think this little duck's o'th mend,

Hoo sleeps so weel to-day;

Doze on, my darlin'; keep 'em shut,-

Those teen $y^{12}$ windows blue;

Good Lord; if aught should happen thee,

What could thi mammy do!

12 Teeny. tiny. 
VII.

Here, gronny, put this cover on, An' tuck it nicely in ;

Keep th' keyther stirrin' gently; an'

Make very little din :

An' lap thoose dimpled honds a:vay

Fro' th' frosty winter air ;

They lie'n a-top o'th bit o' quilt,

Like two clock-hommers theer!

VIII.

But stop; hoo's laughin'" Come, hie up,My bonny little puss !

God bless it! Daddy's noan far off;

Let mammy have a buss!

He's here! He's here! Tet, bring that cheer !

Eh, dear; these darlin's two !

If it wur not for this ehylt an' him

What could a body do! 


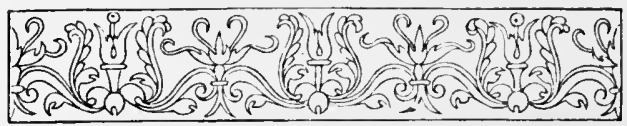

\section{A LIFT ON THE WAY.}

I.

OPM, what's th' use o' fratchin' lads, this life's noan so lung,

So, if yo'n gether reawnd, aw'll try my hond at a sung;

It may shew a guidin' glimmer to some wand'rer astray,

Or, haply, gi' some poor owd soul a lift on the way:

A lift on the way;

A lift on the way;

Or, haply, gi' some poor owd soul a lift on the way.

- Fratchin', quarrelling.

NI $\mathrm{M}$ 
II.

Life's road's full o' ruts; it's very slutehy ${ }^{2}$ an' it's dree ${ }^{3}$

An' mony a worn-eawt limper lies him deawn there to dee;

Then, fleawnd'rin low i'th gutter, le looks reawnd wi' dismay,

To see if aught i'th world can give a lift on the way :

A lift on the way;

A lift on the way;

'To see if aught i'th world can give a lift on the way.

III.

There's some folk 'at mun trudge it, an' there's some folk 'at may ride,

But, never mortal mon con tell what chance may betide;

2 Slutchu. miry. $\quad 3$ Dree, wearily-continuous. 
To-day, he may be blossomin', like roses i' May ;

To-morn, he may be beggin' for a lift on the way :

A lift on the way;

A lift on the way;

To-morn, he may be beggin' for a lift on the way.

Iv.

Good-will, it's a jewel, where there 's little else to spare ;

An' a mon may help another though his pouch may be bare;

A gen'rous heart, like sunshine, bringrs good eheer in its ray,

An' a friendly word can sometimes give a lift on the way:

A lift on the way;

A lift on the way;

An' a friendly word can sometimes give a lift on the way. 
v.

Like posies that are parchin' in the midsummer sun,

There's mony a poor heart faints afore the journey be run ;

Let's lay the dust wi' kindness, till the close of the day,

An' gi' these droopin' travellers a lift on the way :

A lift on the way;

A lift on the way;

An' gi' these droopin' travellers a lift on the way.

VI.

Oh, soft be his pillow, when he sinks deawn to his rest,

That can keep the lamp o' eharity alive in his breast;

May pleasant feelin's haunt him as he's dozin' away, An' angels give him, up aboon, ${ }^{4}$ a lift on the way :

4 Alown, above. 
A lift on the way;

A lift on the way;

An' angels give him, up aboon, a lift on the way.

vII.

Jog on, my noble comrades, then; an'--so mote it be, -5

That hond in hond we travel till the day that we dee;

An' neaw, to end my ditty, lads, let's heartily pray

That heaven may give us ev'ry one a lift on the way!

A lift on the way;

A lift on the way;

That heaven may give us ev'ry one a lift on the way!

$s$ So mote it be, so might it be. 


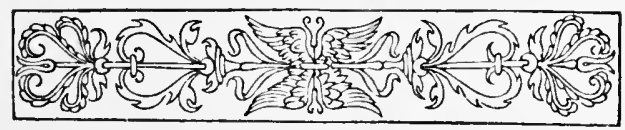

YESTERNEET.

I.

GEET up a-milkin' this mornin',-

I geet up afore it wur leet;

I ne'er slept a minute for thinkin'

What Robin said yesterneet;

I've brokken two basins i'th dairy;

I've scoaded' my gronny wi' tay;

It's no use o' tryin' a-spinnin'-

My wheel's eawt o' trim to-day.

Chorus.-It's oh, yon Robin, yon Robin ;

His e'en ne'er twinkle't so breet,

As they did when he meazur't my finger

For th' little gowd ring last neet!

1 Scoaded, scalded. 
II.

Eawr Dorothy's singin' i'th shippon ; ${ }^{\varepsilon}$

Eawr Jonathan's leawngin' i'th fowd ; ${ }^{3}$

Eawr Tummy's at th' fair, where he lippens ${ }^{4}$

O' swappin' his cowt for gowd $;^{5}$

My gronny's asleep wi' her knittin',

An' th' kittlin's playin' wi' th' yarn ;

Eawr Betty's gone eawt wi' a gallon

To th' chaps at their wark i'th barn.

Chorus.-But oh, yon Robin, yon Robis.

III.

Th' lasses an' lads are i'th meadow ;

They're gettin' their baggin'6 i'th liay;

2 Shippon, sheep-pen, cattle-shed.

3 Leaungin' i'th foud, lounging in the fold.

4 Lippens, expects.

S Suapin' his cout for goud, exchanging or selling his colt for gold.

- Buggin', the aternoon meal. 
I yer 'em as leetsome as layrocks,';

I' th sky on a shiny day;

But, little care I for their marlocks ; ${ }^{8}$

I dunnot want folk to see,

'Though I'm fitter for cryin' than laughin', There's nob'dy as fain as me.

Chorus.-For oh, yon Robin, yon Robin!

IV.

When I crept into th' nook wi' my sewin',

My mother peeped rcawnd so sly;

Hoo know'd I wur glentin' at th' eoppice,

Where Robin comes ridin' by ;

Then hoo coom to me, snurchin' an' tootin', An' whisperin', "Heaw dost fecl?

7 Layrocks, larks.

8 Marlucks, frolics, pranks. 
Dost think I should send for a doctor?"

But, th' doctor hoo knows reet weel.

Chorus.-It's oh, yon Robin, yon Robin!

v.

My feyther sits dozin' i'th corner,--

He's dreamin' o'th harrest day :

When Robin comes in for his daughter,-

Eh, what'll my festher say!

Th' rosebuds are peepin' i'th garden:

An' th' blossom's o'th apple tree;

Oh, heaw will life's winter time find us.-

Yon Robin o' mine, an' me!

Chorus.-Oh, yon Robin, yon Robin!

VI.

Then, hey for kisses an' blushes,

An' hurryin' to an' fro ;

$x \mathrm{x}$ 
An' hey for sly, sweet whispers,

That nob'dy but me mun know!

Then, hey for rings, an' for ribbins,

An' bonnets, an' posies fine!

An' eh,-_it's o' in a flutter,-

This little fond heart o' mine!

Chorus.-For oh, yon Robin, yon Rohin ;

His e'en ne'er twinkle't so breet,

As they did when he meazur't my finger

For th' little gowd ring last neet !

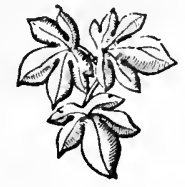




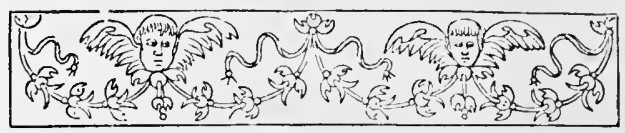

BONNY NAN.

I.

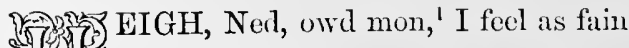

As th' breetest brid 'at sings i' May;

Come, sit tho deawn; I'll wear' a creawn;

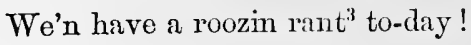

Let's doance an' sing; I 've bought a ring

For bonny Nan i'th Owler dale ;"

Then heigh for fun; my mopin's done :

An' neaw I'm brisk as bottle't ale!

I Oud mon, old man, a friendly phrase, applied to hoth old and young.

2 I'll wear a creaun, I'll spend five shillings.

s Roozin' rant, a rousing frolic.

- I'th Ouler dale, in the dale of the Owler trees. 


\author{
Oh, guess, owd brid, \\ What's beawn to be; \\ For I like Nan,- \\ An' hoo likes me!
}

II.

Twelve months i' weeds, when Robin dee'd, Hoo look'd so deawn, wi' ne'er a smile;

I couldn't find i' heart or mind To cheep ${ }^{5}$ ' weddin' for a while;

I thought I'd bide; but still I sighed For th' mournin' eleawd to clear away ;

I watched her e'en groo breet ${ }^{6}$ again,A layroek tootin' eawt for day !?

- Cheep, to chirp, to hint at, to allude to slyly.

6 Groo breet, grow bright.

7 A layrock tootin' eawt for day, a skylark peeping out for the dawn of morning. 
Then, guess, owd brid,

What's beawn to be;

For I like Nan,-

An' hoo likes me!

III.

My Nanny's fair, an' trim, an' rare:

A modest lass, an' sweet to see;

Her e'en are blue, her heart it's true,--

An' Nanny's hardly twenty-three;

An' life's so strung, when folk are yuug;

That waitin' lunger wouldno do $;^{8}$

These moor-end lads, hoo turns their yeds,

Hoo's bin a widow lung enoo !"

- Waitin' lunger vouldno do, it would not do to wait any longer.

9 These moor-end lads, hoo turns their yeds, she is turning the heads of these lads who live at the edges of the wild moors.

10 Hoo's oin a widow lung enoo, she has been a widlow long enough. 
Then guess, owd brid, What's beawn to be;

For I like Nan,-

An' hoo likes me!

IV.

I've sin, at nect, abeawt a lect, ${ }^{\prime \prime}$

A midge keep buzzin' to an' fro,

Then dart at th' shine, 'at looked so fine,

And brun his wings at th' end of $o^{\prime} ;^{12}$

That midge's me, it 's plain to see,-

My wings are brunt, an' yet, I'm fain;

For, wheer I leet, ${ }^{13} \mathrm{I}$ find so sweet,

I's never want to fly again!

Then guess, owd brid,

What's beawn to be ;

For I like Nan,-

An' hoo likes me!

11 At neet abeawt a leet, at night about a light.

12 An' brun his wings at th' end ov o', and burn his wings at the end of all.

13 Leet, alight, drop upon. 


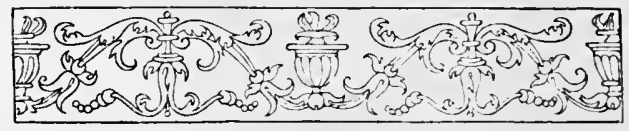

I'VE WORN MY BITS O' SHOON

A IVAY.

I.

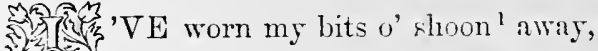

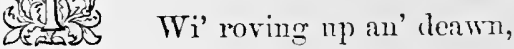

To see yon moorlan' valleys, an'

Yon little country teawn:

The dule tak shoon, and stockin's too!

My heart feels hutchin'-fain;

An', if I trudge it bar-funt, ${ }^{2}$ lads,

I'll see yon teawn again!

1 Shoon, shoes.

2 Rar.fuut, bare-foot. 
II.

It's what eare I for cities grand,-

We never shall agree;

I'd rayther live where th' layrock ${ }^{3}$ sings;

A country teawn for me!

A country teawn, where one can meet

Wi' friends, an' neighbours known ;

Where one can lounge i'th market-place, An' see the meadows mown.

III.

Yon moorland hills are bloomin' wild At th' endin' o' July ;

Yon woodlan' cloofs, an' valleys green,The sweetest under th' sky;

- Th' layrock, the sky-lark. 
Yon dainty rindles, ${ }^{4}$ danein' deawn

Fro' th' meawntains into th' plain ;-

As soon as th' new moon rises, lads, I'm off to th' moors again!

IV.

There's hearty lads among yon hills, An' in yon country teawn;

They'n far moor sense nor preawder folk,--5

I'll peawnd it for a creawn ;

They re wick an' warm at wark an' fun, ${ }^{7}$

Wherever they may go,-

The primest breed o' lads i'th world,-

Good luck attend 'em o'!

4 Dainty rindles, pretty rlls of singing water.

s Moor sense than preauder folk, more sense than prouler people.

- Ill peawnd it for a creawn, I will nphold it for a crown.

7 Wick an' u.rm at wark an' fun, lively and earnest at work and fun.

00 
282 I'VE WORN MY BITS O' SHOON AWAY.

V.

Last neet I laft the city thrung, 8

An' climbed yon hillock green ;

An' turned my face to th' moorlan' hills,

Wi' th' wayter i' my e'en ;

Wi' th' wayter wellin' i' my e'en ;-

I'll bundle up, an' go,

An' I'll live an' dee i' my own countric,

Where moorlan' breezes blow !

8 Last neet I laft the city thrung, last night I left the city throng.

a Wi'th wayter i' my e'en, with the water in mine eyes.

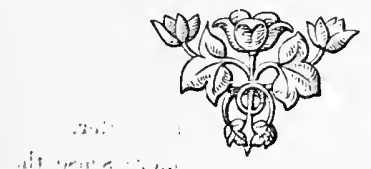

.fu 


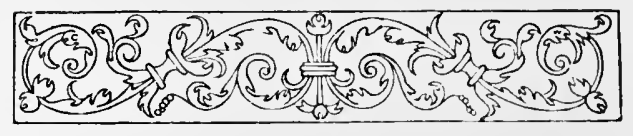

\section{GENTLE JONE.}

\section{I.}

3.

(3) His face were mild, his toppiu't rray!

Wi' wanderin' fuut he weut astray,

\section{Deawn yon lone: ${ }^{3}$}

T axed a lame owd mon i'th road,

To tell me what that ehap were eo'd ;'

Says he, "I thowt oitch body" knowed

Gentle Jone!"

I I see'd a thoutful, I saw a thourlitful.

2 Torpin', the hair on the front of the hearl.

a Lone, Iane.

4 Co'd, called.

5 Oitch body, each body, ach dersun. 
II.

"Owd lad," said I, "just look heaw ronk".

These daisies groo'n at th' erlge o'th bonk ;

Let's keawer us deawn, an' have a conk,-_

Just whol 9 noon."

He poo'd a reech ${ }^{10}$ o' bacco eawt,

An' cheese an' moufin in a cleawt ;"

An' then began to tell abeawt

Gentle Jone !

III.

Says he, "Some folk o' brass ${ }^{12}$ are fond ;

They're cowd i'th heart, an' eramp't i'th hond $;^{13}$

6 Romk, rank, abundant.

7 Bonk, a bank of land, a gentle slope.

8 Conk, a chat.

Whol, while, until.

10 Reech, a smoke.

1 Moufin in a cleawt, muffiu in a clout, or kerchief, or cloth.

12 Brass, mouey.

13 They' re cowd i'th heart, an' cramp't i'th hond, they are cold in the heart, and cramped in the band. 
But yon's the fleawer of o' this lond,-

Gentle Jone !

His heart's as true as guinea-gowd ; ${ }^{14}$

He's good to folk at's ill an' owd ; ${ }^{15}$

Childer poo'n his lap i'th fowd, $-{ }^{16}$

Gentle Jone!

Iv.

“ I 'll bet a creawn he 's off to th' vale,

To yer some erayter's soory ${ }^{17}$ tale;

I never knowed his kindness fail,-

Gentle Jone!

O'er lill, an' eloof, ${ }^{18}$ an' moss, an' moor,

He's reet weel ${ }^{19}$ known to folk at 's poor;

A weleome fuut at every door,-

Gentle Jone!

14 Guinea-gowd, guinea gold, or gold without alloy.

is Oud, old. 16 Fowd, fold. 17 Soory, sorry.

18 Cloof, clough glen. 19 Reet weel, right well. 
v.

" He taks delight i' roving round,

To root i' nooks where sorrow's found;

He comes like rain to drufty ${ }^{20}$ ground,-

Gentle Jone!

He 's very slow at thinkin' ill ;

He'll pass a fant ${ }^{21}$ wi' reet good will ;

An' doin' good 's liis pastime still,-_

Gentle Jone!

VI.

“An' when I broke this poor owd limb,

I should ha' dec'd except for him."

He said no moor; his e'en geet dim,-

Mino were th' same:

20 Drufty, droughty, parched.

21 Pass a faut, forgives a fault, or an offenct . 
" Owd brid," said I, " let's have a gill !"

"Naw, naw," said he, "I 'm noan so weel ;"2

It's time to paddle deawn this hill,

To th' owd dame."

vil.

'Twere nearly noon, i'th month o' Mas;

We said we'd meet another day;

An' then th' owd crayter limped away

Deawn th' green lone

An' neaw, let's do the thing that 's rect,

An' then, when death puts enwt er leet, ${ }^{2.3}$

We's haply ston a chance to meet

Gentle Jone!

22 Noan so well, not very well.

23 Put eawt er leet, puts out our light.

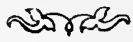




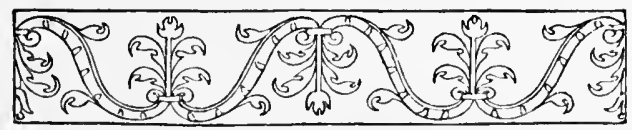

TUM RINDLE.

J.

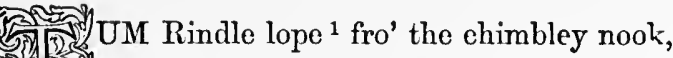
As th' winter sun wur sinkin':

I'm tire't o' keawrin' ' here i'th' smooke, An' wastin' time i' thinkin':

It frets my heart, an' racks my broo--

It sets my yed a-stewin':

A mon that wouldn't dee a foo,

Mun up, an' start a-doin'!

1 Lope, leaped.

Keawrin' sitting, crouching. 
II.

Then, Mally, reitch ${ }^{3}$ my Sunday shoon,

To rom my bits o' toes in ;

An' hond mo th' jug, fro' top o'th' oon,-

An' let mo dip my nose in!

An', eome, an' fill it up again ;

An' dunnot look so deawldy ;

There's nought can lick a marlock, ${ }^{5}$ when

One's brains are gettin' meawldy.

III.

Aw'll laithe ${ }^{6}$ a rook o' neighbour lads,--

Frisky cowts, ${ }^{7}$ an' bowd uns;

An' let 'em bring their mams an' dads;

We'n have it pranked wi' owd uns !

3 Reitch, reach.

S Marlock, frolic.

1 Cowts, colts.
4 Deauldy, down-hearted.

- Laithe, invite.

P P 
An' th' lads an' lasses they sha'n sing,

An' funt it, leet an' limber ;8

An' Robin Lilter, he shall bring

His merry bit o' timber!

IV.

An' Joe shall come, an' Jone, an' Ben;

An' poor owd limpin' 'Lijah ;

An' Mall, an' Sall, an' Fan, an' Nan,

An' curly-pated 'Bijah ;

An' gentle Charlie shall be theer;

An' little Dick, the ringer ;

An' Moston Sam, - aw like to yer

A snowy-yedded singer!

V.

I'll poo mi gronny eawt o'th' nook, An' send for Dolly Maybo',

8 Fuut it leet an' limber, foot it light and nimble. 
For, when hoo's gradely donned, ${ }^{9}$ hoo'll look

As grand as th' queen o' Shayba ;

An' little Nell shall doance ${ }^{10}$ wi' me,-

Eawr Nelly's yung an' bomy ;

An' when aw've had a donnce wi' thee,

Aw'll caper wi' my gronny !

VI.

Then, Mally, fill it up again;

An' dunnot look so deawldy;

There's nought can lick a marlock, when

One's brains are gettin' meawldy !

We're yung an' hearty; dunnot croak,

Let's frisk it neaw, or nover;

So, here's good luck to country folk, An' country fun, for ever!

${ }^{9}$ Gradely donned, properly dressed.

10 Dounce, dance. 


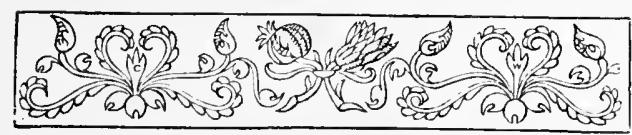

THESE MAUND 'RIN' E'EN.

I.

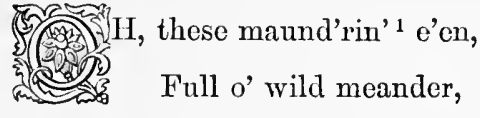

After Mally Green,

Olez ${ }^{2}$ upo' th' wander !

Top to toe, aw'm queer ;

Weel aw may one look wizzen ${ }^{\circ},{ }^{3}$

Foolish when hoo's hear-

Crazy when hoo isn 't !

Chorus-Oh, these, \&c.

1 Maunderin', wandering.

s Wizzen't, shrivelled.

2 Olez, always. 
II.

True love-though so shy,

In a eorner, creepin',

Through some slifter, ${ }^{4}$ sly,

Connot howd ${ }^{5}$ for peepin';

Cruttle $^{6}$ ne'er so still,

Thinkin' noan 's to know him-

Smoor ${ }^{7}$ it as he will,

Summat 's 8 sure to show him.

Chorus-Oll, these, \&c.

III.

Neaw his cheeks are seen,

Flushed wi' tell-tale burnin',

Neaw, his faithful e'en,

To his darlin' turnin';

4 Slifter, crevice.

5 Connot howd, cannot help, caunot resist.

- Cruttle, crouch.

$?$ Sinoor, smotber.

\& Summat, something. 
Wheer the heart will be,

Th' wits are sure to wander;

What one likes to see, At it they mun glendur. ${ }^{9}$

Chorus-Oh, these, \&c.

IV.

To her, neet an' day,

Still my fancy sallies,

Oh,-I dar not say,

That it's same wi' Mally's

If my yed's a foo,

T'mends it noan to skelp ${ }^{10}$ it,

What's a lad to do

When he connot help it?

Chorus-Oh, these, \&c.

9 Glendur, stare. In Skelp, beat, strike, chastise. 
v.

If one's heart's so warm

That it's hard to bille it,

It mun come to harm,

With a foo's to guide it:

Oh, my bonny lass,

End this jinglin' blether' ${ }^{11}$

'Th' heart an' yed,-bith riass,

Tak it o' together !

Chorus-Oh, these, \&c.

VI.

Tak' my e'en, an' then,

$I$ 's know wheer to find 'om ;

$\mathrm{Ne}$ 'er to rove again,

While they 'n thee to bind 'em;

"Blether, disorderly din. 
Swap ${ }^{12}$ my love for thine,

Link 'em ne'er to sever ;

Make this heart o' mine

Hutchin' fain ${ }^{13}$ for ever!

Chorus-Ob, these, \&c.

12 Swap, exchange.

is Hutchin' fain, restlessly glad, fidgety with joy.

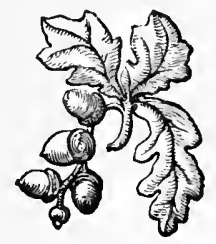




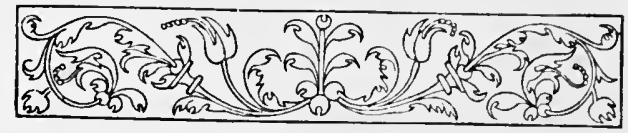

COME, LIMBER LADS.

I.

OME, limber ${ }^{1}$ lads, so lect an' gay,

Aw'm fain we're wick an' hearty ;

To-neet we'n have a haliday-

To-morn we's find it warty : ${ }^{2}$

Like sailors, thrut ${ }^{3}$ bith stormy main

Into a nook together-

One hour o' friendly fun, an' then,

Again for wind and weather.

1 Limber, lithe, active. $\quad 2$ Warty, wark-day, work-day.

3 Thrut, thrown.

Q Q 
II.

Owd Time-though, when a mon's i'th dumps,

He's seldom in a hurry-

Nips up his shins, an' off he stumps,

The minute one gets merry ;

Life's road-though noan as dree ${ }^{4}$ as his-

It's harder wark to travel ;

One leets o' few sich nooks as this, An' th' journey ends i' th gravel.

III.

Then clink and sing, my lucky lads, An' frisk it while yo're able;

There's cheepin' layrocks ${ }^{5}$ round the board, An' plenty upo' th' table.

Come, crack yo'r jokes, an' let 'em leet, O' sly deception scornin';

- Dree, wearily, continuous.

s Cheepin' layrocks, chirruping larks. 
We'n prank it out wi' glec to-ncet, An' strike to wark i' th mornin'.

IV.

If o' that wanders under th' sky

Be grass, that winnot linger,

Let every mortal blade that's dry

Cock up his little finger.

Then, fill for him that's full o' fun-

An' let it be a thumper ;

An' th' lad that thinks he's welly ${ }^{6}$ done,

We'n rooze him wi' a bumper!

v.

An' now, to end this friendly rant,-

Turn up yo'r tots ${ }^{7}$ to th' ccilin';

Let's hope that he may ne'er feel scant

That's never scant o' fecling !

- ITelly, well-n'y, well-nigh.

7 Tots, little drinking vessels. 
Good luck to th' lad that wants a wife, Wi' rosy ehens ${ }^{8}$ to bind him ! An' th' mon that wants a foo-bith lifeI' th lookin'-glass he'll find him !

8 Chens, chains.

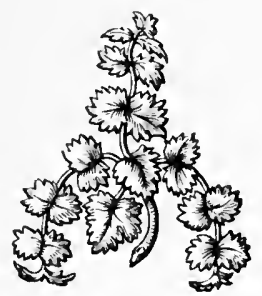




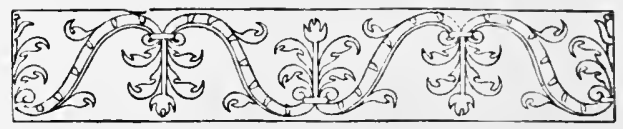

THE GARLAND.

Air-"Cupiel's Cranlen."

I.

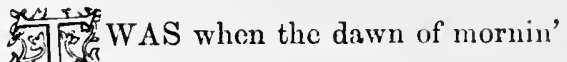

Began to stir i'th sky,

I donned mysel' to wander

Afore the dew wur dry;

To wander in the gay greenwood,

Reet early I did rove,-

I could not sleep upon my bed

For thinkin of my love. 
II.

Down in a bonny dingle,

Where sometimes we did stray,

Our vows of love to mingle,

At close of summer day ;

It's there, where oft among her hair

The flowers of spring I've wove,

I sat me down to think upon

The girl that I do love.

III.

It's there I made a garlan',

My darlin' for to don,

And the posies that were in it,

They shinéd like the sun ;

The dewy posies, wild and sweet,

All in the leafy grove;

It breaks my heart to think upon

The girl that I do love. 
IV.

The cowslip, and the speedwell,

With a dewdrop in its e'e,-

An' the wild rose, an' the bluebell,

They blend so bonnilie;

An' the honey-suckle, wand'rin wild,

With violets blue, I wore,

They made me for to think upon

The girl that I do love.

จ.

An' when I poo'd my posies,

The small birds they did sing;

An' when I wove my garlan',

They made the woods to ring;

On every tree, the wild birds' glee,

Rang throngh the leafy grove,

As I came away, at dawn of day,

Still thinkin' of my love. 
VI.

$\mathrm{Oh}$, the mornin' sun it rises

To cheer my heart's delight, An' the silver moon she wanders

Among the clouds at night;

An' the twinklin' stars that look so fine,

All in the hearens above,-

At wark or play, by neet an' day,

I'm thinkin' of my love.

THE END. 


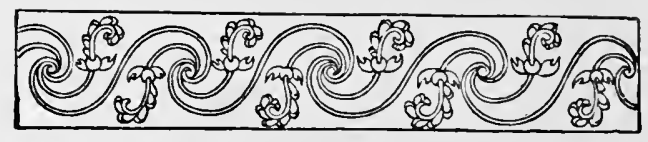

\section{LIST OF SUBSCRIBERS TO THE LARGE}

\section{PAPER EDITION OF WAUGH'S}

\section{POEMS AND SONGS.}

Acton, H. M., Esq., 3, Cross Street, Manchester.

Alston, John A., Esq., Northwood House, Grange Court, Gloucester.

Armitage, Elkanah, Esq., The Rookery, Pendleton.

Arthur, James E., Esı.., Blackburn.

Ashworth, J. Wilding, Esq., Sorrel Bank, Eccles Old

Road, Pendleton, Manchester.

Ashworth, W., Esq., 26, Grafton Street, Preston.

Aspden, Th. A., Esq., Eldon Place, Blackbmrn.

Backhouse, T. J., Esq., York Cliffe, Billington, near Blackburn.

Barlow, Mark, Esq., Hooley Range, Heaton Chapel, near Manchester.

Barton, Richard, Esq., West Leigh Lodge, Leigh.

Beard, Jas., Esq., The Grange, Burnage Lane, Manchester. 
Beaumont, George, Esq., Jun., 11, Piccadilly, Manchester.

Bennett, Captain II. A., Esq., Nelson House, Chorltonon-Medlock, Manchester.

Binns, J. A., Esq., Oak Lane, Manningham, Bradford.

Bleasdell, Rev. John, B. A., Enville P'lace, Ashtonunder-Lyne.

Bolton, Joseph A., Esq., Rose Cottage, Alderley Elge, near Manchester.

Bolton Subscription Library.

Bowes, John, Esq., Warrington.

Bridson, IIenry, Esq., Warfleet, Dartmouth, S. Devon. Bridson, W. Paul, Esq., Stoneclough, Manchester.

Bright, Right Hon. John, Esq., M. P., Rochdale.

Bright, Councillor 'Thomas, Esq., 94, Mill Street, Ancoats, Manchester.

Bromiley, John, Esq., 14, Cateaton Street, Manchester. Brook, Peter Wm., Esq., Marsden House, High Lane. Brookes, W. M., Esq., Sutton Schools, Isle of Ely. Brookes, W. Cunliffe, Esq., Bank, Manchester. Brown, Councillor W., Smedley House, Cheetham. Browning, Thomas, Esq., King Street, Manchester. Buckley, Samuel, Esq., F. R. C. S., 2, Stonewall Terrace, Cheetham Hill, Manchester.

Burton, J. H., Esq., 5, Trafalgar Square, Ashtonunder-Lyne.

Byrom, Thomas, Esq., 27, Dicconson Street, Wigan. 
Carlisle, Henry, Esq., 3, Marquis Road, Canonbury, London.

Chadwick, John, Esq., The Green, Haydock.

Charter, John, Esq., Clifton Ilonse, Ileaton Norris, Manchester.

Chorlton, Thomas, Esq., Manehester.

Clark, William, Esq., Dickinson Road, Rusholme, Manchester.

Clayton, G. R., Esq., Broughton Park, Maneliester. Collinge, Benjamin, Escl., Collinge Street, Rocludale. Cooke, Thomas, Esq., Rusholme Irall, Manchester. Corbett, Edward, Esq., 24, Barton Arcarle, Manchester. Cox, Joseph, Esq., 219, Chester Road, IIulme, Manchester.

Crippin, William, Esq., Seymour IIouse, Old Trafford, Manchester.

Crompton, Samuel, Esq., M. D., 24, St. Ann's Square, Manchester.

Crowley, Walter, Esq., Smedley New IIall, Smedley Lane, Manchester.

Daglish, R., Esq., Aston Irall, Preston Brook.

D'Auquier, J. C., Esq., 67, Cecil Terrace, Greenheep, Manchester.

Dawson, Mark, Esq., Jackson Street Mills, Manchester.

Devonshire, His Grace the Duke of, IIolber IIall, Carke in Cartmel, Carnforth.

Dewhurst, Mrs. J. II., Skipton, Yorkshire. 


\section{LIST OF SUBSCRIBERS.}

Dillon, Jas., Esq., Union Bank, York Street, Manchester.

Draper, John, Esq., Jymm.

Edmondson, R. H., Esq., Brookfield, Lymm.

Evans, George, Esq., F.R. S. L., 57, Hyde Grove, Plymouth Grore, Manchester.

Evans, John, Esq., 17, Brazenose Strect, Manchester.

Farrar, James, Esq., 12, Market Street, Bury.

Fenton, Robert, Esq., Marland, near Rochdale.

- Ferns, A. E., Esq., Waterloo IIouse, Stockport.

Fildes, Henry Strettell, Esq., North View, Stretford, near Manchester.

Forrest, Alex., Esq., Holt Town, Manchester.

Foster, Peter, Esq., Holly Bank, Turton.

Fox, T. F. Embleton, Esq., Northorpe Hall, Kirton-in-

Lindsay, Lincolnshire.

Fraser, Mr. Councillor, Windsor Road, Oldham.

Furness, William, Esq., 9, Kingthorp Grove, Nelson Street, Rusholme, Manehester.

Garnett, William, Esq., Querumore Park, Lancashire.

Gibb, James, Esq., 41, Mosley Street, Manchester.

Gillespie, Thomas J., Esq., Park House, Newton-leWillows.

Gillibrand, T. W., Esq., 50, George Street, Manchester. Gouldthorp, William, Esq., 37, Cross Street, Manchester. Grantham, John, Esq., 2, Rothsay Place, Old Trafford, Manchester.

Gratrix, Samuel, Esq., Alport Town, Manchester. 


\section{LIST OF SUBSCRIBERS.}

Greenhalgh, James, Esq., Solicitor, Bolton.

Grimshaw, W. J., Esq., Wellfield, Stand, near Manchester. IIadfield, Charles, Esq., Editor of the Examiner, Warrington.

Hadfield, George, Esq., Manclester.

Iall, John, Esq., Solieitor, Chorley Road, Bolton-leMoors.

Hall, S., Esq., 61, Princess Strect, Manchester.

Hall, William, Esq., Eecles.

Hamcr, W. E., Esq., 8, Old Exchange Arcarle, St. Ann's

Passage, Manchester.

Hargreaves, Benjamin, Fisq., Arder, Acerington.

Harrison, William, Esq., F. S. A., D. L., and J. P., Samlesbury Hall, near Preston.

Hartwright, H., Esq., Wellington, New Zealancl.

Haserick, F. A., Esq., Newstead IIouse, Whalley Range, Manchester.

Hatton, James, Esq., Richmond IIouse, Higher Broughton, Manchester.

Haworth, Abraham, Esq., Helston IIouse, Altrincham.

Haworth, Jesse, Esq., Manchester.

Hecht, Edward, Esq., Wynnstay Grove, Fallow Field, Manchester.

Hewitt, William, Esq., Fallow Field, Manchester.

Higgin, W. H.Esq., Q.C., St. James's Square, Manchester. Hill, John, Esq., Woodlea, Cheadle IIulme, near Manchester. 


\section{LIST OF SUBSCRIBERS.}

Holt, Edwin, Esq., Exchange Strcet, Cheetham, Manchester.

Holt, John, Esq., Long Street, Middleton.

Hough, Ezra, Esq., Bolton.

Houghton, Robert, Esq., Lowton House, Lowton.

Johnson, Wm., Esq., 25, Lansdowne Terrace, Alexandra Road, Manchester.

Johnson, Miss, 11, Portland Street, Southport.

Kershaw, James, Esq., Holly House, Bury Old Road, Manchester.

Knowles, Henry, Esq., 191, Regent Road, Salford.

Lamb, James, Esq., Jolnn Dalton Street, Manchester.

Leake, Robert, Esq., The Dales, Whitefield, Manchester.

Lee, George, Esq., Corporation Brewery, Tipping Street, Ardwick, Manchester.

Leech, J. J., Esq., Marple, Cheshire.

Lees, Samuel, Esq., Broughton Park, Cheetham Hill, Manchester.

Lees, Samuel, Esq., Park Bridge, Ashton-under-Lyne. Lynde, James H., Esq., 17, Cooper Street, Manchester. Macdonald, James, Esq., F. R. G. S., 17, Russell Square, London, W.C.

Markendale, Riehard, Esq., Godly, near Manchester.

Mart, Joseph Forcaux, Esq., J. P., 28, Crescent, Salford.

Manchester, J., Esq., Brazenose Club.

Mangnall, William, Esq., Prestwich, Manchester.

Mayhew, Walter, Esq., Woodlands, Wigan. 
McKerrow, John Begg, Esq., Noreliffe, Broughton Park, Manchester.

McMiunies, John Gordon, Esq., J. P., Summer House, Warrington.

Meakin, W. H., Eaq., 52, Claremont Grove, Fitzwarren Street, Seedley, Pendleton, Mauchester.

Meredith, Charles, Esq., 49, King Street, Manchester.

Morgan, W., Esq., Liverpool.

Mückley, W. J., Esq., Withington, near Manchester.

O'Neill, Arthur, Esrı., 336, Oxford Road, Minchester.

Partington, Thomas, Esı[., Miles Platting Institute, Manchester.

Patteson, Alderman Heury, Esq., J.P., Anson Road, Victoria Park, Manchester.

Peacock, Rich., Esq., Gorton Iall, Gorton, Manchester. Pearson, George, Esq., Southside, Wimslow, Cheshire. Pearson, J., Esq., Golborne Park, Newton-le-Willows.

Picton, James A., Esq., J.P., F.S.A., Sandyknowe, Wavertree, near Liverpool.

Pierce, Frederick MI., Esq., M..D., 361, Oxford Road, Manchester.

Poole, A. C., Esq., Fallowfield, Manchester.

Pope, Samuel, Esq., Q. C., 59, Laneaster Gate, London, W.

Potter, Chas., Esq., Artist, Werneth, Oldham.

Ramwell, Robert, Esq., German Mill, Bolton.

Ramsbotham, James, Esq., Crowborough Warren, near Tunbridge Wells. 
Reynolds, W. H., Esq., The Willows, Grappinlall.

Ridgway, John, Esq., Lymm.

Ridgway, J. C., Esq., Sankey Bridge, Warrington.

Rigby, Samuel, Esq., Bruche IIall, Warrington.

Roberts, Herbert, Esq., Warrington.

Roberts, John M., Esq., Cornbrook, Manchester.

Roberts, R., Esq., 150, Oldfield Road, Salford.

Robinson, Francis, Esq., 12, Old Millgate, Manchester.

Rose, Thomas, Esq., 14, Bank Street, Cross Street, Manchester.

Rothwell, Edward, Esq., Winwick, Newton-le-Willows.

Rothwell, Selim, Esq., Beech View, Bolton Road, Pendleton, Manchester.

Rothwell, Selim, Esq., India Buildings, 20, Cross Street, Mauchester.

Rowley, C., Esq., Jun., The Glen, Church Lane, Harpurhey, Manchester.

Rowson, James A., Esq., Latchford.

Royds, Ernest E. M., Esq., Leehurst, Rochdale.

Salford Free Library.

Saunders, William, Esq., Hareden, Clitheroe.

Scorah, Henry, Esq., 240, Infirmary Road, Sheffield.

Shackleton, William, Esq., Vale Manse, Todmorden.

Shaw, R. R., Esq., Lorne Street, Chorlton-on-Medlock, Manchester.

Sheffield, G., Esq., The Laurels, Wimslow.

Shiers, Geo. Alfred, Esq., The Grange, Chelford, Cheshire. 
Shiers, Richard, Esq., The Grange, Chelford, Cheshire. Slagg, John, Esq., 12, Pall Mall, Manehester.

Smith, J. Stores, Esq., Chesterfield.

Stainforth, S. K., Esq., Poynton, Stockport.

Steinthal, S. Alfred, Esq., 81, Nelson Street, Manchester.

Stokes, R., Esq., Mab Holes.

Sutton, E., Esq., 41, John Daiton Street, Manchester.

Swindells, Rupert, Esq., 2, Drayton Terrace, Old Trafford, Manchester.

Swinglehurst, Henry, Esq., J.P., IIincaster IIouse, near Milnthorpe.

Tatton, Thomas Egerton, Esq., Wythenshawe IIall, Cheshire.

Taylor, Edward, Esq., Islington Square, Salforl.

Taylor, Henry, Esq., 8, Jolm Dalton Street, Manchester.

Taylor, Samuel, Esq., 14, St. James's Sifuare, Manchester.

Thompson, James, Esq., Wetton Bank, Blackburu.

Tiller, J. G., Esq., 9, Rook Street, Minuchester.

Tong, Jọnathan, Esq., Bruze Ilill, Kersal, Manehester .

Turner, Charles, Esq., Idle.

Turner, William Alfred, Esq., The Lanrels, Pendleton, Manchester.

Wardle, William, Esq., 33, Withy Grove, Manehester.

Watts, John, Esq., Ph. D., 21, Brown Street, Manchester.

Weleh, Thomas, Esq., Green Vale, Westhonghton.

Wilkinson, Thomas Read, Esq., Manchester and Silfird Bank, Manehester. 


\section{LIST OF SUBSCRIBERS.}

Williams, Jacob, Esq., 4, Carlton Buildings, Manchester. Wilson, Charles, Esq., Langley Honse, Prestwich.

Windsor, James Smith, Esq., Gloucester Road, Southport.

Winmarligh, Right Hon. Lord, Winmarligh, Garstang. Wood, Richard, Esq., Clairville, Whalley Range, Manchester.

Wood, R. H., Esq., F. S. A., Penrhos House, Rugby.

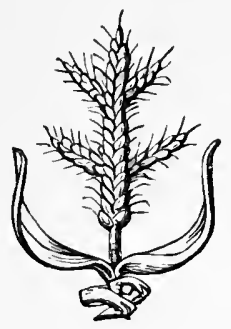




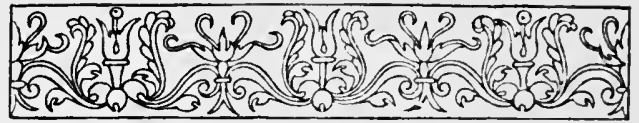

LIST OF

BOOKSELLERS WHO HAVE SUBSCRIBED

TO THE LARGE PAPER EDITION

OF WAUGH'S POEMS

AND SONGS.

Mr. Almond, Blackburn.

Mr. Battle, Manchester.

Mr. Bradshaw, Pendleton, Manchester.

Mr. Cornish, Manchester.

Mr. Day, Manchester.

Mr. Downing, Birmingham.

Mr. John Heywood, Manchester.

Mr. Johnson, Manchester.

Mr. Oakey, Preston.

Messrs. Palmer and Howe, Manchester.

Mr. Pearse, Rochdale.

Mr. Pearse, Warrington.

Mr. Platt, Wigan. 
BOOKSELLERS WHO HAVE SUBSCRIBED.

Mr. Shott, Manchester.

Mr. Slater, Manchester.

Messrs. W. H. Smith and Son, Manchester.

Mr. Stewart, Southport.

Messrs. Tubbs and Brooks, Manchester.

Mr. Wall, Wigan.

Mr. Wardleworth, Accrington.

Mr. Wardleworth, Bury.

Mr. Winterburn, Bolton.

Mr. Young, Liverpool.

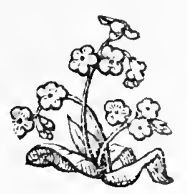

CHISWICK PRESS:-PRINTED BY WHITTINGHAM AND WILKINS, TOOKS COURT, CHANCERY LANE. 



\section{$\checkmark$}

, 
